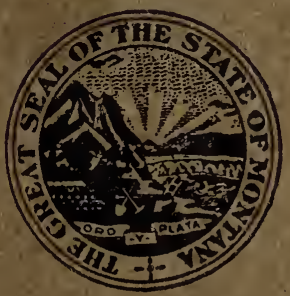




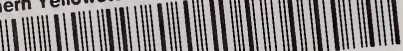

$\underset{30864000396286}{0}$

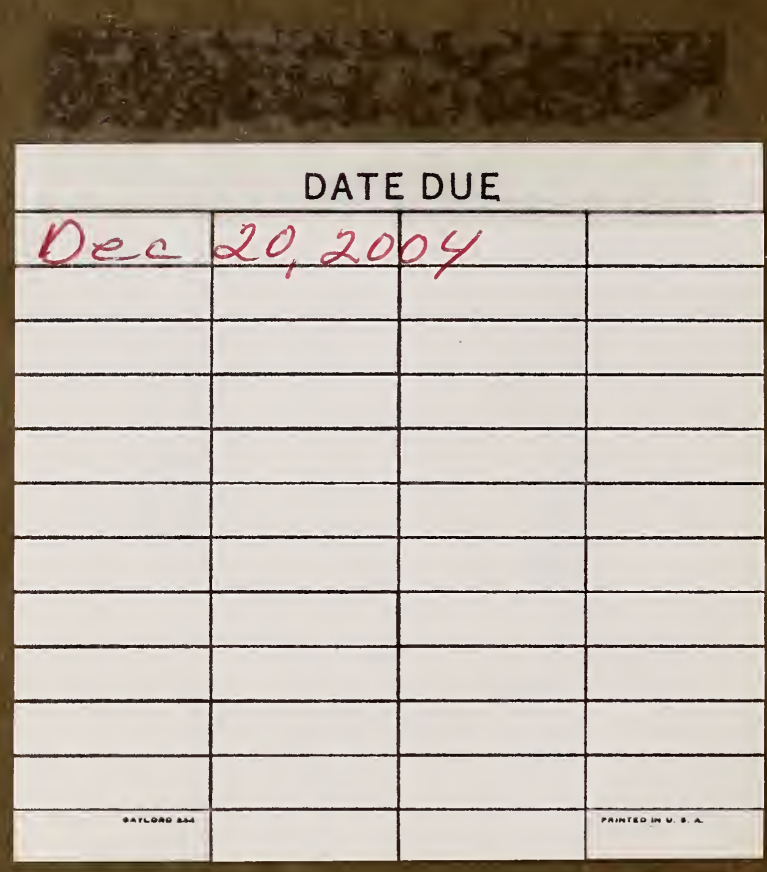




\title{
NORTHERN YELLOWSTONE ELK STUDY
}

\author{
BY \\ W. M. RUSH
}

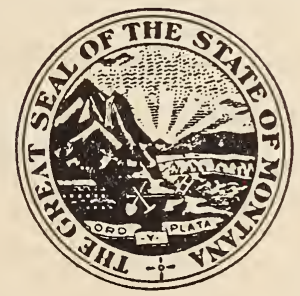

PUBLISHED BY

MONTANA FISH AND GAME COMMISSION 
STATE OF MONTANA

John E. ERICKson, Governor

\section{MONTANA FISH AND GAME COMMISSION William P. Sullivan, Chairman \\ William Steinbrenner $\quad$ B. L. Price \\ Harry P. Stanford William F. FlynN}

Chas. B. Marrs, State Fish and Game Warden and Secretary of the Commission 
Statement of Project …….........................................

Acknowledgments …................................................................. 6

Physiography of Region ............................................. 7

Life Zones .......................................................................... 8

History of Elk in Yellowstone Park _.................................... 11

Life Histcry of Elk .......................................................... 27

Range Conditions ................................................................... 42

Mineral Contents of Forage Plants............................................ 51

Efffects of Foxtail Grass on Game Animals............................... 54

Relation of Heavy Use of Range to Spread of Parasites and

Diseases in Animals

Weed Pests on Winter Elk Range .......................................... 62

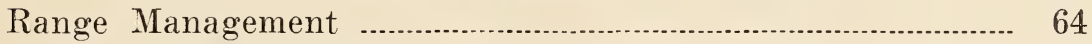

Control of Weed Pests ............................................................... 68

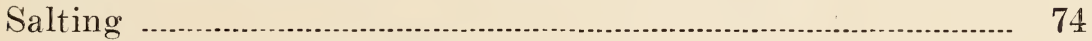

Present Status of Elk Herd .................................................. 76

Wild Life Management …................................................. 78

Responsibility of Management ……................................................ 82

Recreational Value ...................................................................... 83

Losses from Old Age, Starvation and Predators........................ 87

Migrations to Other Areas .................................................... 88

Diseases of Elk ............................................................................ 89

Diseases of Deer ............................................................... 97

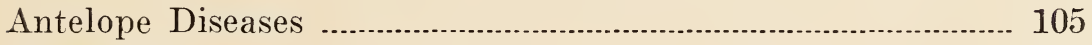

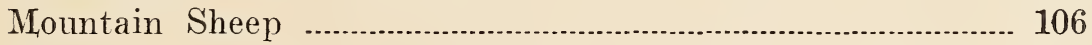

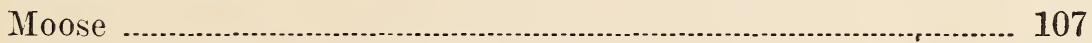

Bang's Disease in the Buffalo Herd........................................ 107

Bear ................................................................................... 114

Methods of Study ............................................................... 119

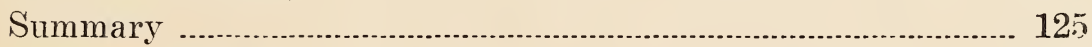

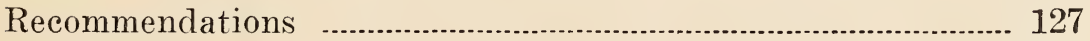

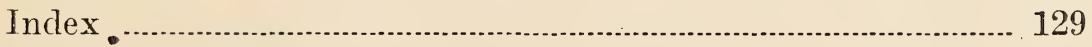


Digitized by the Internet Archive in 2016 


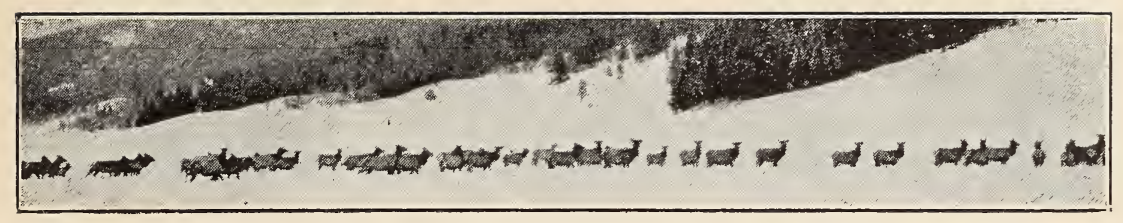

\section{STATEMENT OF PROJECT}

As early as 1911, which was the first year that a heavy slaughter of elk by hunters took place in the vicinity of Gardiner, Montana, definite investigations concerning the ell situation on the National Forests and in the Yellowstone National Park were begun by representatives of the Biological Survey and Forest Service.

The chiefs of the Forest Service and Biological Survey, Mr. Henry S. Graves, and Dr. E. W. Nelson, made a personal investigation of the elk situation in 1917 from which emanated the "Graves-Nelson Report of 1917," containing among its 22 recommendations one for a detailed study of the elk, its habits, life history, et cetera.

The same year (1917) all of the public lands within the area south of Yankee Jim Canyon of the Yellowstone River to the Park line was withdrawn from all forms of entry under the Public Land Laws, except valuable mineral lands. By the Congressional Act of May 26, 1926, all of these lands were added to the Gallatin and Absaroka National Forests and provisions were made for the acquisition of the privately owned lands within the area for additional winter range for the elk.

The need for a detailed study of all the conditions affecting the elk herd was recognized as essential by every one familiar with the problem, but funds to carry on such a study were not available until November, 1928, when Mr. Horace M. Albright, Superintendent of Yellowstone Park (now Director of the Park Service), interested Mr. Thomas Cochran of New York City in the problem. Mr. Cochran generously supplied the funds to initiate and carry on the work from December 1, 1928, to December 31, 1929, the writer of this report being selected by $\mathrm{Mr}$. Albright to be in charge of the study. 
From January 1, 1930, to April 1, 1932, the United States Forest Service, Montana State Game Commission, and the National Park Service have jointly borne the expense with the Biological Survey co-operating in giving technical advice.

\section{ACKNOWLEDGMENTS}

Agencies which have co-operated in giving scientific and technical assistance to the study are: Montana Veterinary Research Laboratory, Bozeman; U. S. Bureau of Animal Industry; Montana Agricultural Experiment Station, Bozeman, Montana; Montana State Veterinarian's Office, Helena, Montana; JensenSalsbury Laboratories, Inc., Kansas City, Missouri; National Park Service; Bureau of Plant Industry; Forest Service.

The writer wishes to make special acknowledgments to the following individuals for their kindly and helpful co-operation: Dr. Frank Nelson, Dr. Maurice C. Hall, Dr. E. A. Tunnicliff, Dr. Hadleigh Marsh, and Dr. William Logan, veterinarians of the State and Federal Bureaus, Mr. Edmund Burke of the Agricultural Experiment Station, Mr. Dorr Yeager, Mr. Joseph S. Dixon of the National Park Service, the District Rangers of Yellowstone National Park, Mr. Thomas Lommasson of the United States Forest Service, and Mr. M. W. Talbot of the Bureau of Plant Industry.

Special thanks are also extended to the officers of the Montana Fish and Game Commission, the National Park Service, the Forest Service, and the Biological Survey for their earnest and sympathetic co-operation with the writer in carrying on the elk study project. 


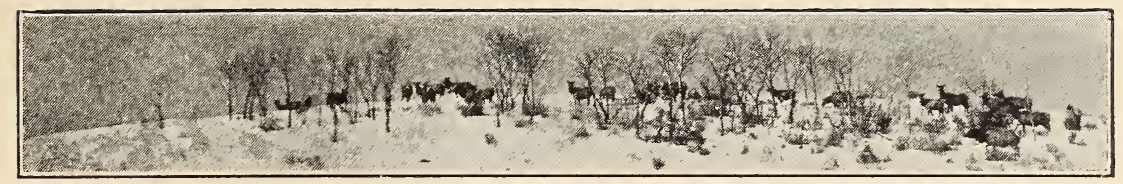

\section{PHYSIOGRAPHY OF REGION}

The range occupied by the Northern Yellowstone elk herd lies south of Yankee Jim Canyon of the Yellowstone River in Park County, Montana, to Big Game Ridge and Thorofare Creek on the south, and west from the Absaroka range to the Madison plateau and Gallatin range. All but a small portion of this area on the west side is drained by the Yellowstone River and its tributaries.

The lower limit of the winter range near Yankee Jim Canyon is at an altitude of about 5,200 feet, while the upper limit of the summer range in Yellowstone Park is above 10,000 feet. The greater part of the Park area is a high plateau at about 8,000 feet, surrounded by high peaks up to above 11,000 feet. About 80 per cent of the Park area is timbered and 20 per cent is sagebrush-grassland. The area north of the Park on the Absaroka National Forest used as winter range are the nontimbered slopes of the Yellowstone Valley ranging from about 7,000 feet altitude down to 5,200 feet.

\section{CLIMATE}

Average for 41 years at Mammoth-Weather Bureau records :

Average annual maximum temperature..............................50.2 ${ }^{\circ} \mathrm{F}$.

Average annual minimum temperature..................................... $27.3^{\circ} \mathrm{F}$.

Relative humidity at noon ......................................................... 52

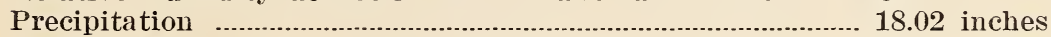

Number of days $32^{\circ}$ or below maximum temperature............ 76

Number of days $90^{\circ}$ or above maximum temperature.............. 0

Number of days $32^{\circ}$ or below minimum temperature.........214

Number of days zero or below minimum temperature........... 22

Greatest annual precipitation ............................................ 28.61 inches

Lowest annual precipitation ................................................... 7.95 inches

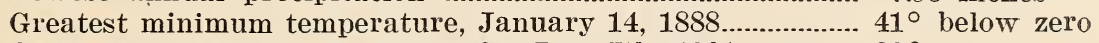

Greatest minimum temperature for July $7 \mathrm{th}, 1901 \ldots \ldots \ldots \ldots . . . . .30^{\circ}$

Greatest maximum temperature for January 27th, 1888...... $49^{\circ}$

Greatest maximum temperature for July 31st, 1896.............. $96^{\circ}$

Greatest maximum snowfall for one year $(1889-1890)$.........200.9 inches

Greatest maximum snowfall for one month (Dec., 1889) .... 60.6 inches

Lowest minimum snowfall for one year (1914-1915) ............ 19.7 inches 
The Mammoth Weather Bureau Station is located at an altitude of 6,239 feet and fairly represents the average for the winter elk range. The floor of the Yellowstone Valley outside the Park is warmer and drier; the upper limits of the winter range on the Lamar River are colder and have a greater snowfall than at Nammoth. The summer range has a much higher precipitation and a lower average temperature than Nammoth. Extremes of $-59^{\circ}$ have been recorded on the upper limits of the winter range at the Buffalo ranch and temperatures as low as $-45^{\circ}$ for short periods are not uncommon.

\section{LIFE ZONES}

Because of the wide range of altitudes in this region with corresponding wide range of temperature and moisture conditions, four of the continental life zones are represented, viz: transition, canadian, hudsonian, and aretic-alpine. Two of the general vegetative areas of the United States are represented, viz: grassland and northern mesophytic evergreen forest.

Because of temperature and moisture conditions, influenced by exposure and altitude, each zone bears types of vegetation and species of animal life more or less restricted to it. The lines between the zones are not sharply marked especially in a mountainous country, one zone merging into another with a corresponding mixture of plant and animal species. The grassland vegetative area of the great prairies merges into the mesophytic evergreen forest area of the Rocky Mountains in this region.

Transition zone: This is the zone in which the great northern prairies lie and it extends through altitudes from about 2,000 feet to above 5,500 feet in the Yellowstone Park region. Plants characteristic of this zone are: Cottonwood (Populus augustifolio), red cedar (Juniperus scopulorum), grayia (Grayia spinosa), wild rose (Rosa fendleri), greasewood (Sarcobatus vermiculatus), salt brush (Atriplex hastata), chokecherry (Prunus melanocarpa), water birch (Betula pontinalis), thistle (Cirsium undulatum), western wheat grass (Agropyron smithii), poreupine grass (Stipa comata), iris (Iris missouriensis), cinquefoil (Potentilla hippiana), mountain rice (Oryzopsis hymenoides), beard-tongue (Pentstemon nitidus), giant rye grass (Elymus condensatus), balsam root (Bal- 
samorrhiza sagittata). Foxtail barley (Hordeum jubatum), and cheat grass (Bromus tectorum), are exotic species largely confined to this zone.

Some of the animal life species representative of this zone are: Cottontail rabbit, antelope, badger, rattlesnake, and woodtick (Dermacentor albipictus). A large part of the winter range of the elk herd lies in this zone.

Canadian zone: This comprises the heavily timbered areas of the Park from about the 5,500 feet to about the 8,000 feet elevations. The characteristic plants are: The great lodgepole pine forests (Pinus contorta), large groves of aspen (Populus tremuloides), low huckleberry (Vaccinium scoparium), Indian paintbrush (Castilleja lauta and other species), purple clematis, Oregon grape (Odostemon aquifolium), bent grass (Agrostis alba), mountain timothy (Phleum alpinum), nodding brome grass (Bromus porteri), tall larkspur (Delphinium sp.), thimbleberry (Rubus parviflorus), goldenrod (Solidago elongata and other species), fire weed (Chamaenerion angustifolium), arnica (Arnicaseveral species), water lily or spatterdock (Nymphaea polysepala).

Representative species of animal life are: Moose, mule deer, red or pine squirrel, flying squirrel, jumping mouse, snowshoe rabbit, Canada lynx, red fox, martin, grizzly bear, Franklin and ruffed grouse, golden eagle, osprey, pelican, blackheaded bluejay, Clark crow, Rocky Mountain jay, cedar waxwing, water ousel, mountain chickadee, and white-crowned sparrow.

The great herds of elk summer in this zone, as do also the buffalo, mule deer, moose, and to some extent the mountain sheep. The lower reaches of this zone are a part of the elk's winter range.

Hudsonian zone: From about 8,000 feet to 9,500 feet. This is the most poorly defined zone in the Yellowstone Park region, being an irregular strip between the bases of the slopes leading down to the plateau and the area above timberline. The stands of timber are scrubby, showing the effect of deep snows and high winds. The principal tree is white barked pine, although alpine-fir and spruce are not uncommon. This is the zone in which occurs the great natural mountain flower beds such as are 
seen in crossing Mt. Washburn. It is much frequented during the summer by moose, elk, buffalo, and sheep as the cool winds at this altitude keep the animals relatively free from pestiferous insects, and the forage plants are fresh and succulent later in the summer than at lower levels.

Arctic-alpine zone: Lies above timberline to the tops of the peaks. There are no trees and the shrubs are much dwarfed by the high winds, cool temperatures, and deep snows. Other vegetation is sparse and the animal life is confined shiefly to visitors from the lower zone, such as mountain sheep, an occasional elk, chipmunks, blue grouse, and marmots. The Coney rabbit and one species of chipmunks are yearlong residents of this high country.

Some characteristic plants are alpine bunchgrass (Festuca alpina), mountain sorrel (Oxyria didyna) draba (Draba breweri), saxifrage (Saxifraga tolmiei), mountain avens (Dryas octopetala), and a species of oat grass (Danthonia). 


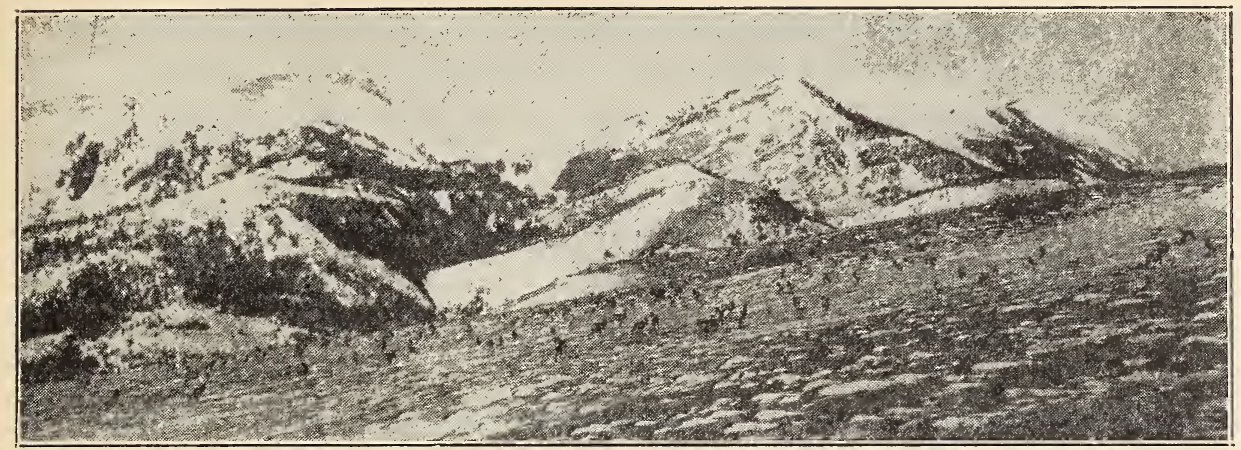

Herd on Winter Range.

\section{HISTORY OF ELK IN YELLOWSTONE PARK}

The local history of the Yellowstone game herds seems fairly well known and is very ably outlined by M. P. Skinner, former Yellowstone Park naturalist, in Roosevelt Wild Life Bulletin, Vol. 4, No. 2, as follows:

"Original Conditions. When pioneers first entered the western plains and mountains they found there a wonderful aggregation of large animals, especially on the broad, wide open prairies and plains. In the mountains, all of the different species were represented by more scattered individuals, probably because the mountains did not contain such a superabundance of food so widely distributed. In later days wild life was more abundant in the mountains. But that this was not so originally, we find very evident from a careful perusal of Lewis and Clark's journals. While they were on the plains, and right up to the time they entered the mountains, these explorers were able to supply themselves with an abundance of fresh meat. But after they entered the mountains, game practically ceased; and when they met the Shoshoni Indians on the headwaters of the Jefferson River even the Indians had only salmon and berry cakes to trade to them (Wheeler, '04, Vol. 2, p. 57). A little later, on September 12, Lewis and Clark speak of the 'scantiness of game' and relate that the Indians had to peel pine trees 'to procure the inner bark for food' (l. c., p. 81). On September 14 they 'killed a colt, on which they made a hearty supper' (l. c., p. 91). And after that, Lewis and Clark were forced to depend on 
horses secured of the Indians, and even on dogs purchased from the same source, for their only food supply.

"And this condition was prevalent all through the mountains; traveller after traveller speaks of the abundance of the buffalo plains and contrasts that abundance with the comparatively gameless mountains in those early and primitive days.

"At a later date, when the hunters and settlers worked steadily west of the Missouri, the larger 'game' animals were forced to retreat toward the mountains. 'Under these conditions not less than 90 per cent of all the big game remaining between the Mississippi Valley and the Pacific Coast has been forced to retreat to the mountains traversing that vast region. There among the rugged peaks and forest-covered slopes which characterize our remaining wilderness are sheltered the survivors of the wonderful hosts of big game animals which once graced so large a part of the continent.' (Nelson, '17, p. 139.)

"From these general conditions, the Yellowstone National Park was not at all exempt: 'As a game country in those early days, it could not compare with the lower surrounding valleys' (Chittenden, '18, p. 11.) When the discovery party led by Washburn, Langford, and Doane, explored the then unknown headwaters of the Yellowstone, they found very few animals present. They speak of an antelope killed in the Blacktail valley and that they had plenty of venison in camp that night, but there was no more game killed during their remaining four weeks of travel through what is now the finest of the Yellowstone game regions (cf. Langord, '05, pp. 15, 19.) In fact, it is really astonishing how few animals this party did see. A black bear was seen near the Mt. Washburn Hot Springs (l. c., p. 23); tracks of grizzlies, etc., were seen near Crystal Falls (l. c., p. 28); tracks of a herd of elk were seen near Park Point and of another herd south of Yellowstone Lake (1. c., pp. 57, $62)$; and a grizzly and cubs were seen south of Yellowstone Lake (1. c., p. 67). In addition, Mr. Langford speaks several times of the panthers' screams heard during the night. But these are remarkably few animals to see in the wilderness during a five weeks' trip. So few, indeed, that I do not wonder that rations were short south of Yellowstone Lake and throughout the remainder of the trip (l. c., p. 83.) 
"The Government Hayden Survey of 1871 saw even fewer animals. Although they had professional hunters with them, employed especially to keep the survey supplied with meat, Dr. Hayden says: 'Our hunters returned, after diligent search for two and a half days (from their camp at South, Arm, Yellowstone Lake) with only a black-tailed deer, which, though poor, was a most important addition to our larder' (Hayden '72, p. 131). And this is the only animal recorded in this report.

"The party conducted by Capts. Barlow and Heap, army engineers, that same year of 1871 , had better success. This party of fifteen men were in the Park about five weeks and evidently recorded every animal seen. Capt. Barlow's official report for July 23, 1871, says: 'One of the men killed a large brown bear and three cubs. The latter were brought in and served our mess with delicious steak for several meals' (Barlow, '71, p. 11). Three days later, Capt. Barlow saw three elk at the foot of the southern slope of Mt. Washburn (l. c., p. 14). On August 12, one member of the party killed a deer near M't. Sheridan (l. c., p. 35), and four days later they 'encountered a large grizzly bear and cub' near Bridger Lake (1. c., p. 37). It is not recorded that they shot this grizzly and cub. Evidently they did not, for the next day 'provisions were just exhausted.' 'Several elk and deer' were seen on Mirror Plateau on August 25 (1. c., p. 40). But just as soon as they came down off the Park Plateau and were on lower ground, they saw 'numerous bands of antelope' in the upper Lamar Valley. The next day, still nearer Mammoth Hot Springs, they killed an elk and a deer (l. c., pp. 40-41). Although I have recorded all the animals seen on an extensive trip, the number is very meagre indeed. Most eloquent of the paucity of game animals is the fact that a party of fifteen all armed, and some at least expert shots, allowed their supplies to become 'just exhausted' eight days before the end of the trip so that they had to send back for more food! Yet this party covered a good deal of territory never before visited by a white man, so far as we know.

“Dr. F. V. Hayden led another government exploring party into the new Yellowstone National Park (set aside as such March 1, 1872) in 1872 and this time they had naturalists attached to the party. Yet these experts 
record only wolverine, skunk, red squirrel, chipmunk, 2 species of mice, Baird's rabbit, and 3 species of bats, collected; and there is no mention of either other mammals or game anywhere in the report (Hayden, '73, pp. 662-669). But Dr. John M. Coulter, botanist of Mr. Stevenson's section of this party, has written an interesting letter, dated April 28, 1924, saying: 'One of the very definite recollections, however, is of a trip I made to the edge of the geyser basin with the professional hunter whose business it was to keep us in fresh meat, when we ran into a tremendous herd of elk; in fact, it was so large a herd that the hunter, who had spent all his life in the west, was surprised at it. An occasional moose came into our camp at night and investigated our tents.'

"In 1873, Capt. William A. Jones, army engineer, led a party of thirty-one men into the Park and remained thirty-one days visiting many new and remote sections. Yet this party, also, had trouble finding game and were soon so short of rations they had to send a party post haste to Fort Ellis, a hundred miles away, for a pack train load. On the east side of the Park, near what is now Pahaska Teepee, 'a mule deer was killed' and furthermore the report says that 'elk, deer, and trout are abundant' (Jones, '74, p. 19). But this territory is on the outside of the Park, and easily accessible from the plains where the animals were then. 'Two bears came down to witness our passage' through Jones Pass on August 2, 1873 (l. c., p. 21). On the same page it is recorded that an elk was killed near Yellowstone Lake the next day. A week later, the report says: 'Provisions are getting low.' (1. c., p. 27.) And from that time until September 2 the party was unable to secure any game, and did not even see any, although they went around Yellowstone Lake and up the Upper Yellowstone Valley, a fine wild animal range at the present time.

"Another party visited the Park in 1873 and left us some interesting records. It was led by Theo. B. Comstock, a noted geologist who was also interested in animals. In fact, he was the first to advocate the desirability of the Yellowstone as a wild animal reserve, but he speaks of the necessity of introducing and preserving animals! He mentions no animals as then in the Park except: "mule deer which is occasionally met 
in this region' (Comstock, '74, p. 75), and 'the order Rodentia is well represented in this section' (l. c., p. 164.)

"In many ways, a party of visitors in 1874 , led by the Earl of Dunraven, has left a still more interesting record, because all its members, except the cook, were experienced hunters. Near Mammoth Hot Springs they killed five antelope to take along as a supply of meat. (Dunraven, '22, p. 289.) On the south side of Mt. Washburn, the party 'found wapiti close to camp, and Campbell fired at but missed a stag. Jack killed one later in the day.' (l. c., p. 192.) An old bull elk, too poor to eat, was killed near the Yellowstone River between Canyon and Hayden Valley. (1. c., p. 204.) But a few days later: 'Meat had been growing very scarce for the last few days. We had scraped clean the bones of the antelope we packed with us from Gardner's River.' So they halted and all hands hunted two days in the upper end of Hayden Valley, where thousands of elk summer now. But Dunraven says: 'Not a single fresh track and nothing whatever eatable to be seen.' (1. c., p. 219.) Two men stayed at this place longer to hunt, while the others visited the geysers and then returned to find the two 'hard up for food, for the country had produced no game (p. 247) . . . we had counted upon getting plenty of game . . . not an atom of fresh meat had we tasted for days' (1. c., p. 288.) During the return of the Dunraven party, they encountered antelope (15 individuals in all) on the Blacktail, and hunted all the way to Mammoth but secured nothing whatever (1. c., pp. 289-295.)

"Capt. Ludlow made a rapid surveying reconnaissance into the Park in 1875 with a party of twentytwo persons, including George Bird Grinnell as naturalist, and was in the Park only two weeks. Just before reaching Tower Creek 'two deer were seen, the only game animals we encountered in the park' (Ludlow, 76, p. 30.) In addition, a cougar was seen on the Yellowstone River near Alum Creek (l. c., p. 63). Dr. Grinnell reports there were considerable numbers of elk and bighorn, and that moose and mountain buffalo were abundant (1. c., pp. 69-71). But this would seem to be based on information from other sources, especially in view of Capt. Ludlow's statement that two deer were the only game animals seen.

"The report of the Hayden Survey of 1878 does not mention any mammals at all except to say that the Falls 
River Basin 'is one of the few remaining haunts of the moose in the Northwest.' (Hayden, '83, Vol. 2, p. 468.)

"The Immigration of Large Mammals. It becomes evident, however, from Grinnell's information that game animals were becoming more abundant, and by 1878 this was noted by several parties. As the period 18701878 coincides with the last great killing on the plains, it seems quite likely that the surviving animals retreated more and more into the mountains, especially in the summer, to escape the slaughter. For a time, probably until a large part of the lowland outside the park was taken up and fenced, these animals that summered in the Park were driven by snow each winter to the plains and lower valleys outside.

"Visitors to the Park since 1878 usually speak of the large number of animals. Capt. F. A. Boutelle, Acting Superintendent, speaks of the increasing number of animals in his report of 1889 (Boutelle, '89, p. 22). Mr. Arnold Hague gives a fascinating picture: "The Park supplies what is really needed-a zoological reservation where big game may roam unmolested by the intrusion of man, rather than a zoological garden inclosed by fences and the game fed or sustained more or less by artificial methods . . All the large game animals of the northern Rocky Mountains are known in the Park except the White goat (Mazana montana) and the caribous (Rangifer tarandus) . . . Elk, moose, deer, antelope, mountain sheep, buffalo and bears are found. . . For elk, the park is an ideal country. They frequent the alpine meadows and grassy terraces, passing freely from one to the other of the open uplands. Where streams flow through these openings, or ponds occupy shallow depressions, the elk resort to them in large numbers during the summer and autumn' (Hague, '93, pp. 252-254)."

The following excerpts, pertinent to the elk of this region, have been taken from the Yellowstone Park Superintendent's reports :

1881-From a report of Harry Yount, gamekeeper:

"The snowfall was unusually great, and remained very deep high in the mountains, but the winds and hot vapors from the Fire Hole Basin at the foot of Mount Norris kept the snow pretty clear along its western slopes, where there were abundance of mountain sheep 
and some elk, all winter. Elk to the number of about 400 wintered in small bands in the valleys of the East Fork and Soda Butte, where the snow was about kneedeep . . .

"I found that very few of the deer or antelope wintered anywhere in the park; that a small band of bison wintered on Alum Creek, and another on the South Fork of the Madison; that there were elk in nearly all of the warm valleys, and moose around the Shoshone and the fingers of the Yellowstone lakes; big-horn sheep on all the mountain slopes . . .'

"From the reports of reliable scouts, familiar with the ranges of the elk, the deer, and the buffalo, there can be but little doubt that there is an abundance of game in the Park. Detachments from my command on the eastern and western sides of the Park have constantly scouted the portions of the Park not frequented by ordinary tourists, and the scout Barronett has also been constantly on the go, watching suspected parties. I am confident that up to the present date there have been no depredations of any magnitude, and that the game has been well protected." derful.

"The number of elk in the Park is something won-

"In the neighborhood of Soda Butte herds were seen last winter estimated at from 2,000 to 3,000. The whole open country of the Park seems stocked to its capacity for feeding. Other varieties of game animals are thought to be increasing rapidly."

"The elk have increased enormously, and most conservative estimates place their number at 25,000 , and $\mathbb{I}$ have no doubts of the presence of that many. Their continuance in the Park is assured, and their overflow into adjoining territory will furnish abundant sport for the hunter."

"Elk. The elk are extremely numerous, and I am not disposed to revise in the least my estimate of 25,000 made last year. The very severe winter was extremely hard on them, and I judge that from 2,000 to 5,000 
perished. This is not an alarming mortality among so many when it is considered that the deaths the previous winter were unusually few. The worst feature of it is that owing to the starved condition of the mothers this spring a very large proportion of the calves perished. There are still as many as the winter grazing will accommodate, and loss of the old ones is not to be considered an evil."

"Elk. For some reason the elk did not winter in the Hayden Valley in the same numbers as formerly. There were abundant signs of them in the autumn, and they reappeared again in the spring. Perhaps many of them stayed in the open valley of the Pelican. The usual large herd wintered in the valley of the East Fork, between Yancy's and Soda Butte. I still believe that there are 25,000 in the Park. While fighting the fire at Norris a few days ago the men saw a herd of about eighty with a large number of calves."

"Elk. The elk wintered well and all reports show a large number of young this spring. A party sent out to Yancy's to investigate the subject in March last saw at least 3,000 of them at one time from a single point of view. This also in the portion of the Park to be cut off by the segregation bill. The valley of the East Fork of the Yellowstone winters more of them than any other portion of the Park, and should it be cut off, it is safe to say that their numbers would be diminished by at least onehalf."

"The elk have quite held their own or increased in numbers, and have been seen almost daily by tourists up to the present date. They exist within the Park in such great numbers that the question of their preservation is not one that causes any concern. A succession of open winters like the last would possibly make them more numerous than the food supply could well support. That they breed and winter within the Park and wander outside of it to furnish sport for hunters is not an evil, and is perhaps one of the very excuses for game protection within its limits."

"Elk. Notwithstanding the hard winter of 189697, which killed many elk and drove many more out of 
the park, there is no perceptible diminution in their number. I believe that more than 5,000 winter in the Park, and that at least 15,000 leave the Park in the autumn to winter in the lower country.

"I happened to be at the south boundary of the forest reserve this year, just after the first snowstorm, on October 13 and 14. The country about Jackson Lake was literally alive with elk, and from the best estimates I believe that 10,000 crossed the south boundary this fall. Many go down the Madison to winter; some down the Gallatin, and some down the Yellowstone. All that survive the winter return to the Park to raise their young, as soon as the snow will permit of their return. Of those that winter in the Park, the largest herd ranges north of the Yellowstone River, in the country that it has been so often proposed to cut off from the Park. I doubt if any more would ever winter in the Park under any circumstances, if this should happen. The Park furnishes an ideal summer range for 40,000 elk, but there is not enough winter range for one-fourth that number."

"Elk. Are more numerous than any other animal in the park. The scouts frequently report seeing herds of a thousand or more. While a great many died last winter, due to the unusually cold weather, yet they are without doubt rapidly increasing. Some of the scouts, from the number of dead ones seen by them, estimate that as many as 5,000 died during the past winter. It is estimated that there are at present from 35,000 to 60,000 in the Park.'

1902

An extract from the monthly report of the Soda Butte Station for the month of December, 1901, shows that on December 7, two men on horseback traveling between Slough Creek Cabin and Hellroaring Cabin saw 20,000 elk in good condition.

1905

" . . . within 5 miles of the main entrance of the Park. After the snow has fallen it is not necessary to go any farther into the Park than this point in order to see all of the wild animals that are to be found within its limits at any season, with the exception of the bear.

"It has been only within the last two or three years that these animals could be seen in such close proxim- 
ity to the Mammoth Hot Springs, and the reasons for this fact are due to a few simple changes in the Park management as follows:

"First. No dogs are allowed to run at large in the park . . .

"Second. A fence about 4 miles long has been built along the northern line of the Park, which excludes all stock that for a number of years has grazed within the limits of the Park and completely used up the grass, which is now preserved for the wild animals. No stock of any kind is now permitted to run at large in the vicinity of the Mammoth Hot Springs, and where they formerly grazed during the summer elk and deer can now be seen feeding during the winter."

"The elk also learned that forage for wild game was being issued at Gardiner, and after the antelope had been fed they came down in large numbers and cleaned up all of the coarser parts of the alfalfa that was not eaten by the antelope. I was told by an exceedingly reliable man in Gardiner that 1,200 elk had been seen and counted on this alfalfa field one evening during the latter part of the winter."

"The number of elk in the park is estimated by persons of some experience at 40,000. From personal observation and information received from reliable scouts, also the daily reports of patrols and guards, 25,000 seems to be a safe estimate."

"Elk. Information from all available sources seems to justify a conservative estimate of between 25,000 and 30,000 elk in the Park. Mr. Wells, in charge of the buffalo farm, an experienced hunter and man of good judgment, estimates the number to be between 40,000 and 50,000. The winter storms and deep snows cause large bands to drift out of the Park down the valleys of the Snake, Madison, Gallatin, and Yellowstone Rivers, where many are properly taken by the licensed hunters, ..."

"A conservative estimate would place the number of elk in the Park at between 30,000 and 40,000." 
"The estimated number of elk in the Park is from 30,000 to 40,000 . Many of these elk wander out of the Park into adjoining states, and a few of them are there killed during the hunting season."

1911

"Elk in certain portions of the Park are very numerous, and are numbered by thousands both in winter and summer. Last winter the deep snows drove them down in large herds from the latter part of November on, and many of them drifted into Montana, where they did much damage to haystacks, fields, and fences on the ranches near the park."

"During last April an approximate accurate census was taken of the elk that winter along the northern border of the Park. Twenty-seven thousand eight hundred and one animals were counted inside of the Park, and 2,300 were observed just outside and, therefore, belonging to the same herd, making a total of 30,101 that actually belonged to the winter herd of the Park. In summer these animals go back into the high mountains in the interior of the Park and but few of them are seen by travelers, and many of the herd that winters in Jackson Hole south of the park also come into the park for the summer."

"A census of elk in and along the north line of the park was taken between April 9 and May 1. The count showed 32,229 , after having shipped 738 , as noted below, making a total of 32,967 , or an increase of 2,866 over the number found by the count of April, 1912. The elk were in excellent condition all winter, and but few dead ones were found. Of 337 dead elk noted by the men making the count, 90 per cent were yearlings."

1914

"A census was again made of the elk, comprising the northern herd in the park, between April 11 and May 2 and showed a total of 35,209 in this herd. Ninetynine were shipped away before the census was taken, making a total of 35,308 , an increase of 3,079 , over the total number found the previous year. In making this count, only 30 dead elk were found. The condition of the herd could hardly be better.' 
"The weather was so mild and there was so little snow in March and April, that the elk went up to high ground earlier than usual, and it was impracticable to take an accurate census of them. They were all in splendid condition, however, and careful estimates by experienced men placed the increase in the northern herd at 10 per cent and the decrease from natural causes at 3 per cent. Taking this into consideration, and deducting 375 elk shipped out of the Park under authority of the department during the winter of 1914-15 leaves an estimated total of 37,192 in the herd."

"As high as 7,000 elk were counted between Fort Yellowstone and a point about a mile west of Gardinermost of them along the main road-on January 27, a day when the weather was particularly severe.

"In accordance with instruction from the department, beginning April 5, 1916, a very careful census was made of the elk belonging to the northern herd in the Park and just along its borders outside on the north and northeast; 29,544 elk were found in this herd and 1,958 more were accounted for-namely, 1,000 (estimated) killed in adjoining states during the open hunting season, 611 shipped from the Park under authority of the department, 90 shipped from just outside of the Park by the authorities of Montana to other points in the state, and 257 counted that had been killed for their teeth in the State of Montana not far from the Park line after the close of the opening hunting season. An unusual increase in the Jackson Hole herd south of the Park, as found by the representatives of the Department of Agriculture referred to above, indicated that a number of the northern herd had probably migrated to the southern herd during the past year.'

"It is important, however, to observe that the percentage of loss in herds of domestic animals in the region surrounding the Yellowstone was considerably greater than the loss in the elk herds.'

"While the wild animals of the Park, with the exception of the bison, have been in excellent condition during the past year, last winter having been mild in 
the extreme, the drouth of the summer has so injured the fall and winter range in the Park and in the adjoining forests that the outlook for next winter for several species of big game, especially the elk and antelope, is anything but promising.'

The Superintendent's report this year is quite lengthy and covers in detail the exceptional conditions prevailing during the winter of 1919-20, when 26.6 inches of snow fell at Mammoth in October with a $-6^{\circ}$ temperature and 20 inches of snow in March with $-25^{\circ}$ temperature. The following paragraph is quoted:

"From the figures given, 19,345 elk in the northern herd in June, 1917, and the fact that the two winters following were quite mild in character with no apparent losses in the herd, it would not seem improbable that there were 25,000 in the herd a year ago. Last June after the most disastrous winter which our wild animals have ever had to face, our rangers estimated the survivors in the northern herd of elk at 11,000, and I am reliably informed that the southern herd fared but little if any better. This loss of nearly 60 per cent in one winter is alarming and indicates most forcibly the possible danger of complete extermination of this most noble race of animals. The story of the long winter of hunger and suffering is heartbreaking. The conditions which caused it were anticipated and preparations on a scale thought to be beyond any possible necessity were made."

"Elk. Weather and forage conditions during the past year have been generally favorable and winter season losses have not been very greatly in excess of normal. All reports indicate a large calf crop this year. Special counts of the Yellowstone herds were made late in February by the Chief Park Ranger and his assistants. Members of the Forest Service and the State Fish and Game Department of Montana also assisted with the counts. The actual counts as submitted are as follows: Total counts with the park 9,807, counts on areas north of park boundary along the Yellowstone River 3,256 , grand total of actual counts 13,043 . Ten per cent was added to the total of the actual counts as a reasonable allowance for all that escaped observation, the amount of this addition being 1,304. The estimated 
total of the Gallatin herd, based on careful observations and partial counts at frequent intervals throughout the winter, is 3,000. The grand total of the actual counts and estimates at the close of February, 1927, was 17,347. This count does not include the Jackson Hole herd. Herd losses during the year are noted as follows: Killed by hunters in hunting areas adjoining the Park 1,099, losses resulting from accident 5, killed by coyotes 5, winter kills including losses caused by tick infestation 548 , shipments to game preserves, public parks and zoos 107, total 1,764. Most of these losses occurred prior to the counts submitted herein."

"Elk. Special observations and counts of the northern elk herd indicate a natural decrease since the close. of February, 1927. The official count secured at that time was 17,347 , which together with the 1927 calf crop estimated at 1,655 made an estimated total of 19,000 at the beginning of the hunting season last fall (1927). The official count submitted on April 16 of this year was 12,853, showing an apparent loss of 6,146 since March 1, 1927. Representatives of the Forest Service, State Game Department of Montana and Yellowstone Park rangers co-operated in securing the count. Additional patrols of the winter elk range in the north district of the park were made later by Mr. William Rush of the Forest Service, Mr. Frank Bellar of the Montana State Fish and Game Department, and Sam T. Woodring, Chief Ranger of Yellowstone National Park, during the period May 7 to 12, inclusive. Two thousand one hundred twenty-eight elk, consisting of 2,099 adults and 29 calves were counted during this time. This ratio indicates that there were less than 300 calves in the entire northern elk herd on May 15, 1928, as compared with an estimated calf total of 1,653 at the beginning of the 1927 hunting season. It appears from the counts and observations that the 1927 ealf crop has been almost a total loss. Large numbers were killed during the hunting season and heary losses no doubt. occurred during the weaning period caused by weakness-and low vitality resulting from the heavy snowfall and unusually severe blizzard conditions of the early winter. The reported losses since early last fall are as follows: Killed by hunters 1,691 , shipments for stocking purposes 184 , winter kills 363, total 2,238. Additional heavy losses have no doubt occurred at distant and isolated points 
as practically all winter losses reported occurred along or near the trails. Fifteen hundred twenty of our winter losses were caused by hunters along the north line, which is by far the largest kill of the past five years. The second largest kill during this period was 1,090 in 1926. The estimated total of the northern elk (including the Madison and Gallatin herds) is 14,150."

From these reports it can be seen that there have apparently been great fluctuations in the numbers of elk in the northern Yellowstone herd and with but one or two exceptions no reason is given for the decreases as will be noted from the following excerpts :

1902-Report :

"last winter was an exceedingly favorable one."

1903-Report :

"past winter exceedingly favorable for game."

1904-Report :

"past winter exceedingly favorable for game."

1906-Report :

"In spite of the heavy fall of snow in the Park last winter, the large game pulled through in good shape, and the percentage of loss was very small."

1912-October 1 :

"The past winter was ideal one as far as game was concerned. The grass was plentiful on the range, and while there was much snow, no crust formed on it, so it was an easy matter for the elk, deer, antelope, etc., to get plenty to eat."

1914

"The weather and other natural conditions for all game were ideal, and the antelope, elk, and mountain sheep wintered in splendid condition."

1916-

"On account of the very severe weather it was predicted that the loss of game during the spring months would be great, but this prediction did not prove true, and the men who in April made a careful census of the elk reported but few dead animals found, and that most of them were in excellent condition."

"The co-operation of the two states, Montana and Wyoming, was particularly valuable the past winter 
when snows almost unprecented in the history of the Northwest drove thousands of elk, antelope, and other animals beyond the Park boundaries."

“. . . a normal winter made the care of elk and antelope herds relatively easy to accomplish, and there was only the usual loss through natural causes."

"last winter having been mild in the extreme . . ."

“. . no forage on the winter range at all, and almost without warning came the unprecedented storm of October 22-23 when from 15 to 28 inches of snow fell in all parts of the Park and effectually sealed up what little forage there was left on the summer and fall ranges. "-Undoubtedly the worst winter in the history of the Park.

"Unusually mild weather was experienced nearly the entire season ..."

1923

"Last winter was favorable to the game and all species came through with few losses."

"The winter was mild and all species of game animals flourished."

"Weather and forage conditions during the past year have been generally favorable and winter season losses have not been very greatly in excess of normal."

In the reports not included no mention is made of winter conditions affecting the elk, nor of any other adverse factors except a limited amount of hunting.

From Mr. Skinner's research into the literature bearing on the early game animal history of the Park area and from the Superintendent's reports it is seen that (1) the Park area was not originally heavily stocked with game animals, (2) the numbers of elk and other animals increased to such an extent that they were forced to migrate from the Park in search of food, and (3) extremely heavy losses occurred in the elk herd during the severe winters. 


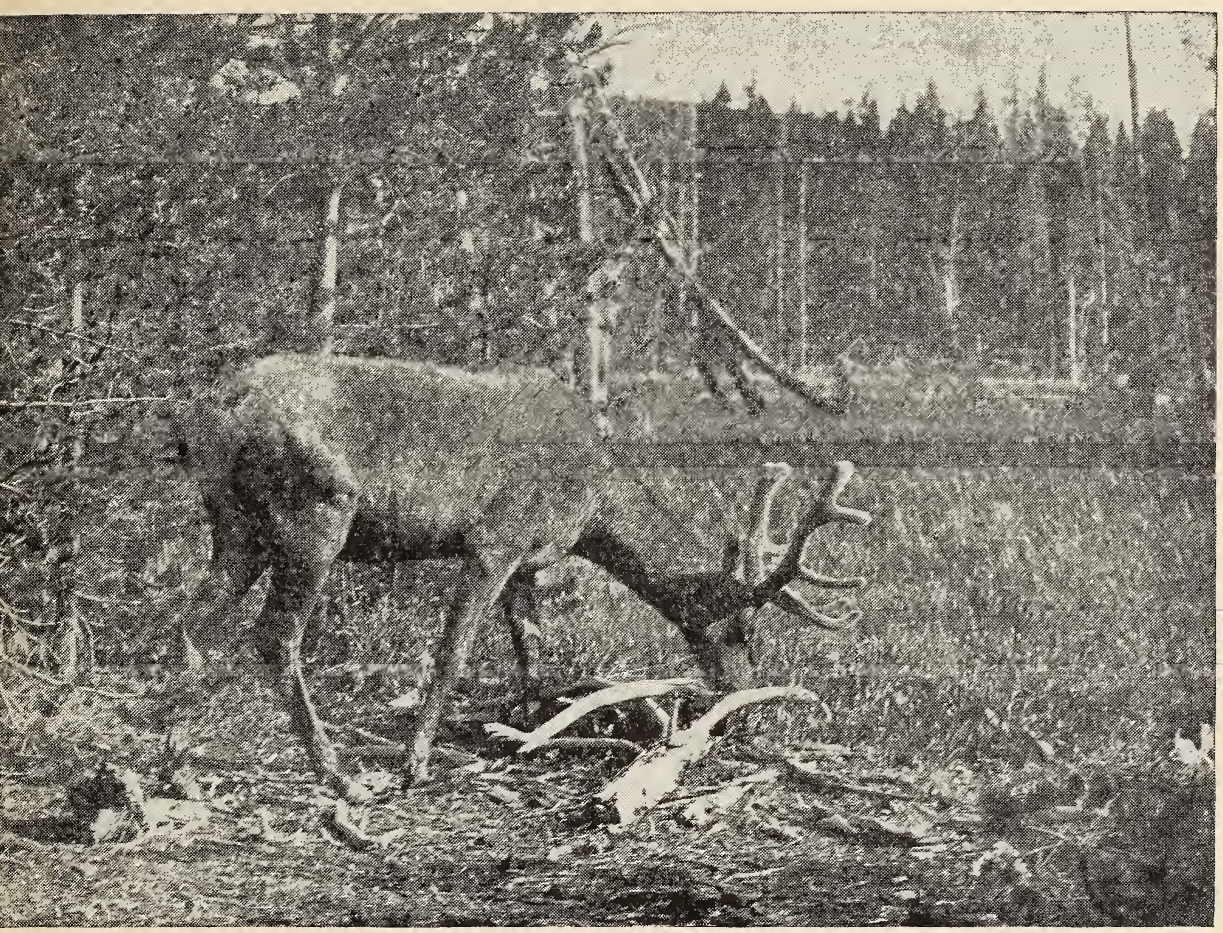

Young Bull in Velvet.

\section{LIFE HISTORY OF ELK}

The information contained in the following report is based on the writer's three years of study of wild animal conditions in this region and his former fourteen years' association with the Yellowstone and Sun River elk herds.

Wild animals of any species are difficult to study-all of their actions during darkness will always be unknown or at best but partially learned-and the observer must constantly be on guard to secure data on the usual habits rather than accept unusual occurrences for the usual. Many accepted theories on animal behavior have been modified as the results of intensive study and as such studies are carried on many more of the popular conceptions of wild animals will change.

Elk are usually classed as very stupid animals but close association with them shows that what is often taken as stupidity 
is in reality some handicap that mankind has imposed on them that has not as yet been overcome. We must remember that our present herds are in an environment not particularly well suited to them and close restrictions for the exercitation of their mental faculties surround them. All grass-eating wild animals are rather low in intelligence compared with the carnivores, but the elk rank high in the deer family and probably somewhat above the bovidiae.

General Habitat. Elk are essentially a grazing animal of the plains and prefer the forage that grows on open range land, mountain meadows and parks. In the Yellowstone region the high grassy ridges and the numerous mountain parks are favorite feeding grounds as are also the great open stretches of Hayden Valley and Pelican Creek. The elk, however, take full advantage of the timberlands surrounding the open areas for shelter from storms in the winter and for shade in the summer. They are not an animal that frequent the swampy areas, as do the moose, nor the high, inaccessible spots such as mountain sheep or goats favor. On the other hand, the elk do not insist on a strictly prairie range as do the antelope. They seem to prefer the prairie type of forage, but like to be near the timber for protection against adverse weather conditions.

Before the settlement of the West the elk herds summered largely in the Transition zone and wintered in the Upper Sonoran zone. At the present time they summer in the Canadian and Hudsonian zones and winter in the Transition and Canadian zones. This factor of increased altitude over natural conditions, with the resultant increased snow depth and shortage of forage, explains the heavy loss in the 7 to 11 months old class of the herd. These young animals cannot overcome the handicap of "short rations" the first winter of their lives without a high mortality. A severe winter also registers its effect on the pregnant animals, indicated by a small calf crop or a large crop of calves below the normal in vitality.

The soils of this region are in general of a high rock or gravel content, usually of a depth of $6^{\prime \prime}$ to $12^{\prime \prime}$, interspersed with small areas of alluvial or diluvial planes of deeper, rich soil. Less than one per cent of the total area used by this elk 


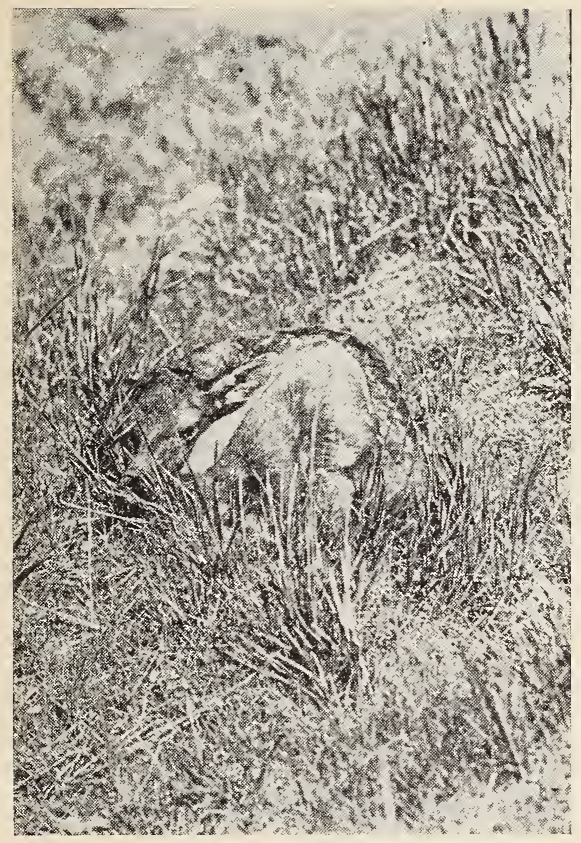

Caif Elk Three Hours Old.

herd is classed as tillable soil. Approximately 75,000 acres of the winter range is of the o p e $\mathrm{n}$ grassland - sagebrush type, the remainder being timbered. This lies at an altitude below 7,500 feet, the summer range being above this elevation.

Calving. May 13 is the earliest date on record here and June 10 the latest date on which newly born calves were found. The calving season is given as May 15 to June 10 with but little, if any, variance each year. Calving takes place on the upper limits of the winter range where the forage is usually well advanced. Some of the early grasses, such as Koleria cristata, are well headed at this time and there is an abundance of both grass and weed forage.

The young are often born in spots where there is no protective cover, such as on closely grazed areas, side of road, old lake bed, alkaline areas, and in one case in a plowed field. Within an hour or so the mother encourages the calf to move to a more inconspicuous spot. Wooded areas are not favored, the calves often being found in the grass or sagebrush within a hundred yards of the edge of the woods. Small aspen groves are sometimes selected as the hiding place but the greatest number favor the open prairie for the first few days.

For the first two or three days after birth the young are readily approached and submit to being handled, apparently without fear. Oftentimes they will follow a person or horse a short distance and in one case two calves played with two children, submitting to petting and following the children about for a half hour, the mothers of the calves standing three or four hundred 
yards distant and apparently not greatly concerned. This, however, is rated as an out of the ordinary case. Usually after the first day the calf will emit a loud, shrill whine and struggle to escape from its captor. When released it will run at top speed until it finds a new place of concealment where it flops down and remains perfectly quiet. In three cases under observation they returned to their original hiding place within two hours' time.

The mother never attempts to molest a person handling the calf. She will come on a dead run when the calf cries but always stops at a safe distance, emitting a loud scolding noise.

The enemies of the young are coyotes, bear, and perhaps some of the predacious birds. The mother aggressively protects her young against coyotes and in one case was observed to furiously chase a magpie away from her calf. However, as she frequently grazes a quarter or even a half mile away from the calf, it gives the coyote a chance to sneak in and kill the little one. If coyotes depended entirely on elk for food at this time of the year no doubt they would kill many more of the calves than they do, but fortunately there is plenty of other food for the coyotes and their depredations on the elk are not great.

The calves depend on protective coloration, lack of odor, and mothers' aggressiveness for safety the first few days. At the age of two weeks they are strong and swift enough to depend somewhat on their speed in escaping from their enemies. Their color is a light brown, with white spots, black on tip of nose, edges of lips and hoofs. This color scheme blends well with green and gray plants, brown earth, various colors of rocks, and decaying ground cover.

All known tests indicate that the young calves have no detectable odors. Coyotes and bear, both black and grizzly, have been observed hunting for them and approaching within a few yards without detecting them. Grizzlies will rear on their hind legs in order to get a better view of the area they are searching. In one case a horse grazed toward a calf in a clump of tall rye grass until his nose was within a foot of the ealf without smelling it. Certainly the human nose can detect no odor as this test has been applied many times without success. 


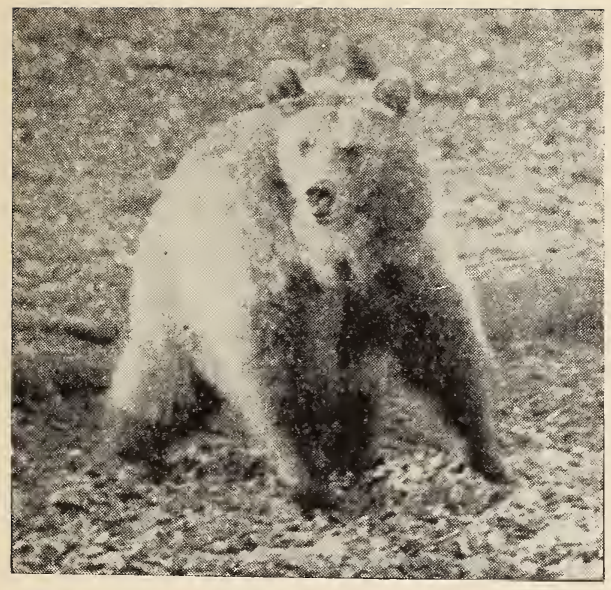

trying to get the bear to chase her. The bear paid no attention to the mother but persistently and systematically searched the sagebrush for the calf, howerer without success, giving the job up after nearly one hour's hunt. The coyote followed along with the bear, evidently depending on the grizzly to make the find.

Nursing periods are not regular, as nursing has been observed at practically all hours of the day, and for different lengths of time, varying from a few seconds to three minutes.

The earliest date that calves have been observed eating grass is July 19. On August 27 six calves were observed eating grass very greedily. Nursing has been observed on such late dates as November 15, January 22, January 29, April 1, April 5, and July 19, the latter case being a yearling that had to get on its knees to nurse. With the exception of November 15, all of these are considered as calves the mothers of whom were not pregnant. The weaning period is over by December 15 , although the calves usually stay with their mothers until the following spring within a month of the calving period.

The average weight of a calf at birth is 37 pounds, the smallest weighed 23 pounds, and the largest 45 pounds. The average measures 40 inches in total length from tip of nose to tip of tail and 291/2 inches high at shoulder. 
Reproduction. Growth of Antlers. Male calves show no indications of antlers. Between the ages of one and two years single tines are grown, varying from $10^{\prime \prime}$ to $18^{\prime \prime}$ in length, and the animal is called a spike. These spikes are retained as late as May 12. After shedding a new set immediately starts to grow, which may be a two, three, or small four point set by August, at which time the animal is about 27 months old. The next and succeeding years, until the age of five is reached, the antlers are larger and are of four, five, or six points. Six points to each antler is considered a full head and measurements taken indicate that a spread of 45 inches, total length outside curve of $501 / 2$ inches and a burr circumference of $91 / 2$ inches, is a larger than average adult set of antlers. The largest set measured here had a spread of $481 / 2$ inches, outside curve 57 inches, and burr circumference of $11 \frac{1}{2}$ inches.

After the first set are shed the next are shed earlier in the season, the earliest noted being on February 20, the usual time March 10; the latest date for a bull older than a spike, May 8. On May 1168 bulls were noted as having new antlers, some with three points. On May 20 one bull with antlers 18" and three with antlers 6 " long were seen. Growth is very fast until about August 1. Complete shedding of the velvet has been noted on August 19 and some not yet started to shed on August 20. On September 12 all bulls, except spikes, had shed their velvet and polished their antlers. Spikes often retain their velvet until the following spring. During and for about two weeks after the shedding of the velvet the bulls rub their antlers on small trees, oftentimes apparently "shadow boxing" with a small tree, knocking off the branches and in some eases uprooting the tree. Cases have been observed where the ground was trampled for 20 feet around a tree by a bull who probably "played" that the tree was a rival bull and showed how he would treat such an antagonist when the occasion arose.

A chemical analysis of a shed antler shows that it is composed of $\mathrm{P}_{2} \mathrm{O}_{5}$ (Phosphorus) $23.22 \%, \mathrm{CaO}$ (calcium) $27.02 \%$, protein $42.06 \%$, and moisture $7.36 \%$. These elements are assimilated into the blood system from the forage eaten and deposited through the circulation in the velvet to form the antler. 
Just why this process must be repeated each year is not known. The entire process seems to be connected in a physiological way with the breeding season.

General Breeding Habits. Shortly after shedding the velvet, or about September 5 to 10, the bulls begin collecting their harems and fighting away other bulls. Bulls with harems have been observed as early as September 12 and as late as October 14 , though at this later date many harems have become combined to make up large herds for the fall migration. The average number of cows in each harem is six, the smallest number observed two, and the largest sixteen. The bulls attempt to keep their harems together, driving the cows away from possible entanglements with other harems and fighting any other bulls which seek to interefere.

The actual breeding season is from September 15 to October 10 and varies but little, if any, from year to year. Probably $90 \%$ of the cows are bred between these dates, the remaining $10 \%$ being bred outside these dates, mostly before September 15 . Some very few cases have been observed as late as November 4. This later date would cause the birth of the calf on July 4 and none have been found later than June 10 .

The bugle is heard as early as the first of September but begins in earnest about September 12 and tapers off to occasional bugles about October 31, with a few heard as late as November 6 . Spring bugling from May 10 to June 20 is not uncommon but apparently has no connection with actual breeding. Young bulls have been observed courting the females at this time and evidently this early bugling is done by them, the "puppy love" of the elk family. During the principal part of the breeding season bugling in such areas as Hayden Valley or Pelican Creek is heard continuously the entire night, the peak being at about 9:00 or 10:00 p. m. The clatter of antlers is also heard continuously for several hours each evening as the bulls battle one another.

Fights are usually tame affairs, one bull giving up the battle after a few clashes of antlers. Fatal terminations are rare, having been observed but twice. In one battle that lasted for about 12 minutes, the vanquished broke away from his opponent and ran 
at top speed, frequently stopping and kicking back very viciously. The calves gaze curiously at the fighting males, but the cows apparently pay no attention.

In courtship the males chase the cows short distances, at a slow trot, nudge them in the sides and rear with nose, caress them with tongue and sometimes strike at an indifferent cow with their antlers. A bull has been observed to devote his entire time to one cow of his harem for several hours at a time, the remainder of the herd paying little attention, except the calves, who do considerable whining.

From the data gathered from cow elk killed by hunters after the breeding season it is found that yearling cows do not breed. About $98 \%$ of the two-year-olds and older, with the exception of the extremely old ones, are pregnant. T'win pregnancy has never been observed.

Migration. The quiet and restfulness of the summer season is broken by the breeding season. Storms coming at the close of breeding and afterwards cause an assembling of the small bunches into large herds of from 50 to 400, or even more, cows, calves, and young bulls. The older bulls pull away from the cows after breeding and in some cases migrate to the winter range ahead of the cows. Usually, however, the bulls stay on the summer range some time after the others have gone. Migration from the summer range is caused by the fact that the elk know through experience, instinct, or otherwise, that the high altitudes are untentable for them in the winter. About $90 \%$ of the northern herd follows one or the other of two routes from the summer range to the winter range, viz., the Dunraven Pass or the Mirror Plateau. The date of the fall migration varies as much as three weeks and the time consumed on the migration routes also varies. Further migration after the winter range is reached is also dependent on available food supply. In January, 1929, no movements of the herds occurred although the temperature ranged down to $41^{\circ}$ below and the snow was from $8^{\prime \prime}$ to $25^{\prime \prime}$ deep, but the snow was not erusted, which permitted the elk to easily paw through to the forage.

A light snowfall in the early part of the winter followed by a thaw, then freezing weather, then snow which crusts, are 
the conditions which effectually seal up the forage so that no grazing animal can subsist and migration to lower levels is their only salvation.

The migrations are slow, deliberate movements occurring largely at night. A bunch of elk in moving from Mountain Creek to Hellroaring Creek probably takes two or three weeks, stopping often for a day or two to graze in some favorable spot, then traveling through the long stretches of lodgepole pine where no forage exists, without pausing. Some apparently purposeless movements have been observed in the fall migration, for instance, on October 30, 1929, a band of some 300 elk on their outward migration through Dunraven Pass met a band of 75 headed in the opposite direction.

- The return migration in the spring starts as soon as snow conditions permit. Calving is nearly all on the winter range, thc cows with newly born calves being the last to go. This return movement is practically completed by June 15. An exception was noted as late as July 11 when 14 cows and 11 calves were observed fording the Lamar River in the early morning heading toward Specimen Ridge.

Insect pests apparently have no bearing on these seasonal movements as flies, gnats, and mosquitoes are present on the summer range as intensively as on the winter range during the summer. Daily movements are no doubt influenced to some degree by insect pests.

Food Habits. Elk have two general feeding periods, one from before daylight until several hours afterwards, the other in the evening from several hours before dark until some time after dark. The length of these periods depends upon the amount of forage readily available. In midsummer the feeding periods are shortest, in winter longest. Between periods they lie down and ruminate. In the summer they usually go to the shade and shelter of nearby wooded lands during the mid-day rest period, and in the winter to the shelter of timber or to the leeward of a small hill. Exceptions are often noted to the two feeding periods; in fact, while observing a band of 25 or more elk any time during the daylight hours, some will be grazing and some 
ruminating. The following is taken from field notes and is indicative of their manner of feeding:

May 20, 1931-56 cows and yearlings near Buffalo Ranch

$3: 45$ p. m.-17 lying down; 39 feeing on grasses

$4: 00$ p. m.-10 lying down; 46 feeding and playing

$4: 20$ p. m. - 9 lying down; 47 feeding and playing

4:40 p. m.- 2 lying down; 54 feeding and playing

With a larger band in the forenoon the following notes were taken :

\section{HELLROARING SLOPES}

5:30 a. m.-40\% lying down; remainder feeding

$9: 00$ a. m.-70\% lying down; count was 667

10:00 a. m.-85\% lying down; remainder feeding

$2: 00$ p. m.-90\% lying down; remainder feeding

Grasses, when available, make up the larger part of the elk's diet. Stomach analysis of elk killed by hunters show that grass is $95 \%$, weeds and browse $5 \%$ of the stomach contents. A band of 17 on Pelican Creek took two to three bites of sage brush (Artemesia cana) to 10 to 14 bites of grass (sedges, bunchgrass, redtop, bromes). Full paunched elk have been observed many times taking bites of sagebrush, service berry, aspen, Douglas fir, or yellowbush which probably indicates that browse, while not the main part of the diet, is a highly desirable part of the menu. The forage weeds are greedily eaten during the summer, especially by the lactating cows.

On the winter range forage is not plentiful and the animals are forced to eat practically every part of every plant that can be chewed. In fact, much of the browse on the winter range has been killed by a too heavy use by elk.

In a following chapter on Range Conditions are listed data on the specific forage plants that elk utilize.

Elk readily accept artificial feeding and soon become dependent. Cottonseed cake is greedily eaten once they have tasted it. Grain oats, grain hay, timothy, and alfalfa are also readily taken. On the feeding grounds they eat very rapidly, getting their paunches full as quickly as possible, then move a short distance away and lie down, making but desultory attempts at securing other forage.

There is no evidence that elk suffer from eating poisonous plants, although death camas (Zygadenus venenosus), larkspurs 
(Delphinium), lupine (Lupinus), water hemlock (Cicuta), and arrow grass (Triglochlin maritima) are more or less common on the summer range. A few tame bulls at Norris have been observed to eat the tops of arrow grass apparently without ill effects. Lupine is eaten on the winter range in small quantities, not sufficient to cause poisoning. Of the other poisonous plants mentioned, no evidence exists to show that they are consumed by elk.

Compatibility. Elk harmonize with the other game animals of this region, using the same range, particularly in the winter and frequently grazing in close proximity to the others. Elk fraternize much less with the buffalo than with the other game animals, but no actual conflicts between elk and buffalo have been observed. The following notes are representative of many instances observed of the different species grazing together:

May 5, 1929-

Fifty-seven antelope intermingled with 634 elk south of Gardiner. Elk and antelope within 25 feet of each other.

April 16, 1931-

Eight elk feeding around two antelope lying down.

Elk came within 30 feet of antelope.

December 17, 1928-

Two bunches of buffalo, 50 and 21, on top of Specimen Ridge grazing in close proximity (within 100 feet) to 65 elk, apparently in perfect accord.

February 12, 1929-

Thirty-five elk down within 150 yards of 65 buffalo that were grazing on Slough Creek.

May 6, 1929-

Elk and deer were seen together in six different bands today. Twice the deer were running along with the elk. Were using the same range in perfect harmony.

February 10, 1930-

Blacktail Creek. One calf elk running with eight deer, no other elk near.

February 13, 1930-

Blacktail, four mountain sheep and five deer were grazing together. 
March 8, 1930-

Elk and sheep grazing within 20 feet of each other near Rattlesnake Butte.

On the buffalo summer range at the head of Lamar River but very few elk are now seen, where formerly large bands regularly summered. This indicates that the elk prefer to graze on a range not used by buffalo.

Physical Characteristics. The average live weight of the adult bull is about 850 pounds, cow 500, and calves on December 1 about 165 pounds. The newly born calves average about 37 pounds, are 40 inches in length from tip of nose to tip of tail, $291 / 2$ inches tall at shoulder, tail $21 / 4$ inches, ear $51 / 2$ inches, and hird foot $16 \frac{1}{2}$ inches.

Color. Calf, December 3 (Ridgeway Standards) black on nose, eyes, edges and tips of ears, mane, border of rump patch and toes. Argus brown to tawny olive from back of neck to sides, darker on belly. Light buff rump patch. Legs darker than body. Darker line along vertebral ridge. Before spring molt body colors are much lighter.

Bull, December 5-black, tip of nose, around eyes, toes, vertical sides of rump patch. Tawny olive on sides grading into Sudan brown in flanks and backs of legs to nearly black on fronts of legs. Rump patch redder than on calves. Belly nearly black.

Before spring molt body colors much lighter, appearing almost white at a distance. After spring molt very rich brown blending to tawny olive and Sudan brown in fall.

Gaits. The gaits are: Walk, trot, and gallop. A series of long leaps is often observed when an elk is frightened, or in fording streams or going through deep snow drifts. The average pace of a band of elk feeding is 14 inches, in migrating 30 inches, trotting 25 inches, and running 41 inches.

Speed. June 1, 1929, tested young cow for speed with auto. Speedometer registered 30 miles per hour for two-tenths of a mile with cow running parallel. Cow crossed road in front of auto. Top speed of this cow was probably 35 miles per hour. October 14, 1930 — chased band of one old bull, two young bulls, 
17 cows, and 6 calves with saddle horse 600 yards. Horse gained for 300 to 400 yards-rode within 80 feet of old bull who traveled behind the band when the terrain became too rough for horse. (The speed of this band was estimated at 30 miles per hour for 600 yards.)

The ordinary saddle horse used in this region cannot run fast enough to get within a stone's throw of an elk on the open range. The elk's best speed is faster than the buffalo, moose, mule deer or mountain sheep, but does not come up to the antelope.

Swimming. Elk are good swimmers, even the small calves, and do not hesitate to take to the water when necessary to ford a stream. When swimming the entire body is submerged with the exception of the head.

Postures. The most common lying down posture observed is similar to that of domestic cattle, viz: head curled against side, feet folded underneath body. The cud chewing position is the same with the exception that the head is held erect. Some have been observed in the dog position, viz: feet stretched out in front, head resting on feet, or all feet under body with head curled against belly. The ealves in hiding nearly always assume the dog posture. Some cases have been observed where but one front leg was stretched out, the other being folded underneath.

In arising the elk always gets on its hind legs first and in lying down gets off its front feet first.

Disposition. The elk is sanguine in temperament. In handling for shipment, or otherwise, they easily become angered and stubborn and are dangerous to their handlers. On the range they are rather vacillatory, not readily making up their minds just what to do and not having any leaders that quickly show them what to do. Their final decision is always to seek safety in flight usually with a cow leading. A notable exception to the general rule that cows assume the leadership in times of danger was observed on the "firing line" on December 2, 1929. Seventeen elk were surrounded by hunters about one-half mile from the Park line, 12 minutes before the time for shooting. After a few minutes of wandering aimlessly inside the cordon of hunters 
an old bull circled the band, took the lead and, disregarding the hunters, headed directly for the Park line, and safety, his little band following him. It was a fine example of determined leadership.

Curiosity is not an outstanding trait in the elk as it is in the antelope, but some interesting exceptions to this have been observed.

The hum of a motion picture camera caused a young cow to approach within 30 feet of a blind in Pelican Valley.

On June 6, 1930, on Prospect Peak, five cows, two spikes, and three yearling cows watched for 42 minutes a camp being pitched, manifesting great curiosity at the unfolding of the tent, unsaddling of horses, et cetera. The yearlings seemed more timid and stayed to the rear of the cows, but they watched the camp operations very intently. The odor of tobacco smoke caused one young bull to evince great excitement. Evidently he enjoyed tobacco smoke.

Playful Antics. Calves play "tag," running, jumping, and pushing each other head to head. Cows' play seems to be rearing on hind legs, sometimes walking five or six steps on hind legs, and striking at each other with front feet, besides running and capering about. Bulls push each other antlers to antlers and also chase each other about. Considerable playing is done in shallow ponds and streams with the resultant great splashing of water.

The senses of sight, smell, and hearing are highly developed in elk as in other members of the deer family.

Elk have not become the "beggars" around Mammoth that the deer and bear have. In two or three cases they have become tame enough to take food from a person's hand but have never been known to submit to "petting" as have the deer. The few exceptions have been elk that were reared as pets.

Recreational Value in Park. Of the thousands of tourists that visit this Park in the summer, many enjoy the sight of bands of elk or individuals. Norris, Elk Park, Gibbon Meadows, and Hayden Valley are places where elk can be seen almost any day of the tourist season, either early in the morning or late at 
evening. The following notes are indicative of the attention paid to wild animals in Yellowstone:

July 10, 1931-Four adult bulls in meadow at Norris. Seventy-six cars stopped to look at these elk and 23 tourists with cameras took pictures in 57 minutes' time. Only two cars (yellow busses) and one motorcycle failed to stop to watch bulls grazing.

August 9, 1929-Stopped eight cars on road near mouth of Alum Creek and allowed tourists to watch band of 76 elk with field glasses. All were highly enthusiastic over the sight.

Many local people come to Yellowstone during the winter months to see the large bands of elk that are near the roads from October to June.

\section{RANGE CONDITIONS}

History of Use. (1) Winter range inside Park. Prior to about 1905 domestic stock were allowed to use that part of the range between Mammoth and the north boundary of the Park without any restrictions as to season of use, numbers, or class of stock. Surplus horses, as many as 3,000 head, used as a reserve in handling transportation of people and freight in the Park, were grazed on Blacktail Deer Creek up to 1916, and the saddle horses used in the Park are still grazed here a part of the season. These number 200 to 300 head.

Sheep and cattle used as a meat supply were grazed in the Park until recent years. A small band of cattle (15 to 30 head) and a few milk cows were grazed at the Buffalo Ranch prior to 1919.

The buffalo herd on the Lamar River at the Buffalo Ranch numbered but 22 in 1902, but has increased to about 1,000 at the present time.

The elk herd was probably at its maximum size in 1915 when the estimated total was 37,192 . 
In September, 1914, the writer rode over the range on Blacktail Creek, Hellroaring to Slough Creek, Lamar Valley near Specimen Ridge, and up Slough Creek, in company with Mr. J. D. Warner, Supervisor of the Absaroka Forest. At that time none of the range showed heavy use except that part of Blacktail Creek used by the horse herd, and a small area north of Specimen Ridge known as the Horseshoe which had had heavy use in the spring by buffalo.

(2) Winter range outside Park. From the time of the settlement of the Yellowstone Valley south of Yankee Jim Canyon in the 1870 's up to 1926 all of the present winter elk range was used for stockraising and the entire area was very heavily grazed by cattle and horses. It was an overgrazed range in 1914 and by 1926 hardly enough forage existed to give hopes of this range ever recovering without extensive artificial reseeding.

Beginning with 1911, the elk left the Park in large numbers and contributed to the depletion of this part of the range. Since 1911 elk varying in numbers from 500 to 7,000 , according to the severity of the winters, have used this outside range a part of each winter.

All domestic stock have been removed from this area since 1926 with the exception of 58 cattle and horses grazed under regular Forest Service permits issued to residents who have lived in this vicinity a long time. 


\section{SUMMER RANGE}

Use is almost wholly by game animals. Domestic stock interference is practically nil.

Koughly stated, the elk summer range lies above the 7,500 foot level and as far south as Thoroughfare Creek and Snake River, where it overlaps to some extent with the summer range of the Jackson Hole elk herd. The total range covered by the northern herd in the summer probably exceeds $1,500,000$ acres and is ample for at least 40,000 elk.

The following brief description of several units of the summer range is given:

\section{HAYDEN VALLEY}

Forage plants identified:

\section{Scientific Name}

Agrostis

Potentilla

Agoseris

Artemisia cana

Festuca idahoensis

Carex

Koleria

Danthonia

Stipa

Agropyron smithii
Common Name

Redtop

Cinquefoil

Mountain dandelion

White sage

Idaho bunchgrass

Sedge

June grass

Oat grass

Porcupine grass

Western wheat grass

Predominantly a redtop-June grass range.

Much used by elk in summer.

Approximate acreage 23,000 acres grassland-sagebrush.

Elevation 7,700 to 8,500 feet.

Soil-obsidian sand in bottoms, gravelly hills.

Open grassland-sagebrush range surrounded by lodgepole pine (Pinus contorta) forest, in which low huckleberry (Vaccinium scoparium) predominates on the forest floor. 
Forage plants :

\section{Scientific Name}

Rumex

Melica

Trisetum

Juncoides

Juncus

Sisyrinchium

Histrix

Agoseris

Bromus

Danthonia

Koleria

Triglochin

Senecio

Eriogonum

Phleum

Pedicularis

Heracleum

Ledum
ELK PARK

\section{Common Name}

Sour dock

Onion grass

Trisetum

Elk grass

Wire grass

Blue-eyed grass

Bottle grass

Mountain dandelion

Mountain brome

Oat grass

June grass

Arrow grass

Wooly groundsel

Eriogonum

Mountain timothy

Lousewort

Cow parsnip

Labrador tea

Elevation 7,400. Good bottom soil.

Much favored summer range. Approximately 1,000 acres.

Spruce (Picea engelmanni), alpine fir (Abies lasiocarpa), and lodgepole pine (Pinus contorta) constitute the principal surrounding forest trees with aspen (Populus tremuloides), willow (Salix sp.) and Oregon grape (Adostemon sp.) as some of the browse types of forage.

Forage plants:

Scientific Name

Vagnera

Allium

Aster

Agrostis

Phleum

Senecio

Rumex

Danthonia

Triglochlin maritima

\section{NORRIS}

\section{Common Name}

False Solmon's seal

Onion

Aster

Redtop

Mountain timothy

Senecio

Sour dock

Oat grass

Arrow grass

Elevation 7,000 feet. Warm, sandy soil along river. Much favored by bulls in summer. Area much broken up by hot springs formation. 


\section{SWAN LAKE FLATS}

Forage plants:

\section{Scientific Name}

Bromus
Festuca idahoensis
Danthonia
Carex
Stipa
Agrostis
Cirsium
Dasiophora
Penstemon
Potentilla
Artemisia tridentata
Artemisia cana

\section{Common Name}

Nodding brome

Blue bunchgrass

Oat grass

Sedge

Porcupine grass

Redtop

Thistle

Shrubby cinquefoil

Beard tongue

Cinquefoil

Sage

White sage

Elevation 7,000 feet-almost level-good soil-sagebursh. Approximately 10,000 acres open range-late summer and early spring range.

\section{WINTER RANGE}

The winter range comprises, roughly stated, the valley of the Yellowstone and its tributaries from Yankee Jim Canyon to 7,500 feet elevation. During winters of heavy crusted snow this is restricted to a lower elevation, depending entirely upon the depth of snow and condition of crust. The types of forage plants differ somewhat from that of the summer range as is indicated by the following :

\section{GARDINER RANGE}

Mammoth to Gardiner west to Sepulcher.

Forage plants :

\section{Scientific Name}

Koeleria cristata

Bromus tectorum

Hordeum murinum

Hordeum jabatum

Oryzopsis hymenoides

Poa

\section{Common Name}

June grass

Cheat grass

Barley grass

Foxtail barley

Mountain rice

Blue grass 


\section{Scientific Name}

Lolium multiflorum

Sisyrinchium

(occidentale)

(augustifolium)

Iris missouriensis

Linum lewisii

Balsamorrhiza sagittata

Potentilla

Geranium

Lupinus

Rush (scirpus)

Rosa fendleri

Achillea millefolium

Antennaria reflexa

Eriogonum

Lappula

Sarcobatus vermiculatus

Grayia spinosa

Elymus condensatus

Penstemon

Astragalus

Macronema

Atriplex

Carex

Populus tremuloides

Prunus melanocarpa

Ameranchier

Juncus

Juniper

Cirsium

Chrysothamnus
Common Name

Italian rye grass

Blue-eyed grass

Wild iris

Wild flax

Balsam root

Cinquefoil

Geranium

Lupine

Rush

Wild rose

Yarrow

Everlasting

Eriogonum

Stickseed

Greasewood

Hop sage

Giant rye grass

Beard tongue

Vetch

Iron plant

Salt brush

Sedges

Aspen

Chokecherry

Service berry

Wire grass

Juniper

Thistle

Yellow brush

Elevation-5,300 to 6,200 feet.

Soil-gravelly. Open-a little timber. Area open winter range 4,000 acres.

Growing season-April 1 to June 15. Killing frosts August 20 -north and east slopes.

Overgrazed. Erosion of top soil occurring. Forest type juniper, Douglas fir, and lodgepole pine.

Heavily used by domestic stock (cattle and horses) prior to 1905 . 


\section{BLACKTAIL}

West of creek to slope of Everts north of road.

Forage plants :

\section{Scientific Name}

Artemisia

Dasiophora fruticosus

Vagnera

Geranium viscocissimum

Lupinus

Astragalus

Senecio

Eriogonum

Poa

F'estuca

Agropyron sp.?

Agropyron spicatum

Koeleria cristata

Carex

Stipa comata

Salix

Populus

Juncus

Chrysothammus

Elymus condensatus

Phleum alpinum

Potentilla

Balsamorrhiza

\section{Common Name}

Sagebrush

Shrubby cinquefoil

False Solmon's seal

Geranium

Lupine

Vetch

Wooly groundsel

Eriogonum

Blue grass

Bunchgrass

Wheat grass

Wheat grass

June grass

Sedge

Porcupine grass

Willows

Aspen

Wire grass

Yellowbrush

Giant rye grass

Mountain timothy

Potentilla (Cinquefoil)

Balsam root

Elevation 6,000 to 7,000 feet. Acreage winter range, average winter 2,000 acres.

Soil gravelly-rocky-upper limits better-good along small valleys.

Open non-timbered sagebrush slopes, north exposure.

Growing occurs April 15-July 1. Killing frosts August 10.

Badly overgrazed-erosion of top soil occurring.

Antelope and horse summer range.

Used by elk and saddle horses early in spring. 


\section{LAMAR VALLEY}

Above Junction Butte, south of river.

Forage plants :

\section{Scientific Name}

Stipa
Artemisia frigidia
Chrysothammus speciosus
Agropyron
Festuca idahoensis
Poa
Elymus canadensis
Carex
Agrostis
Muhlenbergia squarrosa
Calamagrostis canadensis
Bromus porterii
Aira caespitosa
Stipa richardsonii
Cirsium
Juncus

\section{Common Name}

Porcupine grass

Silver sage

Yellowbrush

Wheat grass

Idaho bunchgrass

Blue grass

Canada rye grass

Sedge

Redtop

Dwarf Muhlenbergia

Meadow pine grass

Nodding brome grass

Tufted hair grass

Richardson grass

Thistle

Wire grass

Elevation 6,000 to 6,500 feet. Much used winter range. Gravelly soil, rather poor grade. Overgrazed.

Erosion of top soil occurring. Antelope summer range. Used to limited extent by saddle horses in summer. Used by buffalo in fall, winter, and spring.

Practically all of this winter range is badly overgrazed to the extent that sheet erosion has occurred the past few years and much of the rich top soil washed away. The original stand of grass is badly disturbed and weakened and the reduction of root competition by the grasses for moisture has allowed such undesirable plants as Yellowbush (Chrysothammus sp.) to become prevalent. Other plant indicators of overgrazing are Western wheat grass (Agropyron smithii), dwarf Muhlenbergia (Muhlenbergia $s p$.$) , and several species of weeds.$

During the summer of 1929 nine experimental plots were established on the winter range in the Park to determine if Hungarian brome grass would establish itself on the overgrazed range. It had previously been noticed that this same grass or a very closely related species had in some manner established itself in a 
small strip along the road between Tower Falls and Mammoth, and as this grass fulfills all the requirements of a winter forage grass it is thought that artificial reseeding might be a partial solution to the bad range situation. Hungarian brome had also been seeded with a nurse crop of oats at Gardiner and is quite common around the Game Preservation Ranch from which hay had been eut and packed to many points in the Park. The results of this experiment were largely vitiated by the drouth of 1930 and 1931.

The removal of all commercially used saddle horses to some other area would greatly relieve the situation, as loose horses are very severe on a range, more especially so during the spring months when the ground is soft and the grasses young and tender. Also some arrangement might be made whereby the buffalo herd could be kept from using the lower part of the Lamar range early in the spring when trampling does so much harm.

Outside of the Park the winter range was in a most deplorable condition the summer of 1926 . This area is covered with sagebrush and was so heavily grazed up to 1927 that hardly enough grass remained on it to give any hopes of it ever recovering without extensive artificial reseeding. Exclusive of the cultivated lands, the soil in general is of rather poor grade, with a high rock or gravel content. However, on areas from which all stock has been excluded the forage has rejurenated itself to a most unexpected degree.

Forage plants growing on winter range outside Park:

\section{Scientific Name}

Agropyron spicatum

Elymus condensatus

$P o a$-several species

Stipa-several species

Bromus inermis

Bromus porterii

Koleria cristata

Oryzopsis hymenoides

Phleum pratense

Lolium multiflorum

Hordeum jubatem

Carex - several species
Common Name

Blue bunch-wheat grass

Giant rye grass

Blue grass

Porcupine grass

Smooth brome grass

Nodding brome

June grass

Mountain rice

T'imothy

Italian rye grass

Foxtail barley

Sedge 
Scientific Name

Achillea

Geranium

Lupinus

Artemisia tridentata

Populus tremuloides

Cirsium

Balsamorrhiza sagittata

Atriplex

Rosa

Prunus

\section{Common Name}

Yarrow

Geranium

Lupine

Sagebrush

Aspen

Thistle

Balsam root

Salt bush

Wild rose

Chokecherry 

JULY 18 TO 21,1930

Analysis by Montana Agricultural Experiment Station, Edmund Burke, Chemist

Percentages of Tricalcium Phosphate Formed by

Resultant Excess of Calcium or Phosphorus.

\begin{tabular}{|c|c|c|c|c|c|c|c|c|c|c|c|c|}
\hline Location and Common Name & $\begin{array}{l}\text { Estimated } \\
\text { Palatabilty }\end{array}$ & $\begin{array}{l}\text { Per Cent } \\
\mathbf{P}_{2} \mathrm{O}_{n} \\
\end{array}$ & $\begin{array}{l}\text { Per Cent } \\
\text { CaO }\end{array}$ & $\begin{array}{l}\text { Per Cent } \\
\text { MgO }\end{array}$ & Ash & $\begin{array}{l}\text { Crude } \\
\text { Flber }\end{array}$ & $\begin{array}{r}\text { Ether } \\
\text { Extract }\end{array}$ & Protein & $\begin{array}{l}\text { N. F. } \\
\text { Extrict }\end{array}$ & $\begin{array}{l}\text { Resultant } \\
\mathrm{Ca}_{3}\left(\mathrm{PO}_{3}\right) 2\end{array}$ & $\begin{array}{l}\text { Excess } \\
\mathrm{P}_{2} \mathrm{O}_{8}\end{array}$ & $\begin{array}{l}\text { Excess } \\
\mathrm{CaO}\end{array}$ \\
\hline IIasden Valley: & & & & & & & & & & & & \\
\hline $\begin{array}{l}\text { 1. Forcupine Grass... } \\
2 \text { Idaho IBunch Grass . . . . . Festuca idahoensis }\end{array}$ & 75 & .4574 & .461 & .163 & 5.42 & 25.65 & 2.98 & 14.00 & 51.05 & 0.851 & 0.067 & \\
\hline $\begin{array}{l}\text { 2. Idaho Iunch Grass .......................Festuca idahoensis } \\
\text { 3. Mountain Timotbr .................. Phlew alpinum .... }\end{array}$ & .. $\quad 80$ & .4404 & .680 & .196 & 9.80 & 23.77 & 3.63 & 14.94 & 47.86 & 0.961 & & 0.160 \\
\hline 3. Mountain Timotby ................... Phleum alpinum .. & 70 & .3958 & .390 & .174 & 3.41 & 27.78 & 2.31 & 8.88 & 57.62 & 0.720 & 0.066 & \\
\hline 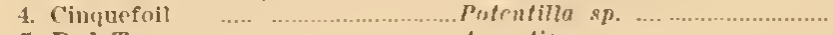 & .. $\quad 30$ & $.5 \$ 29$ & 1.052 & .554 & 5.12 & 24.95 & 2.01 & 11.38 & 56.54 & 1.273 & $\ldots \ldots .$. & 0.302 \\
\hline 5. Red Top & ... 70 & .3914 & .544 & .176 & 5.63 & 26.81 & 2.04 & 9.44 & 56.08 & 0.854 & ......... & 0.081 \\
\hline 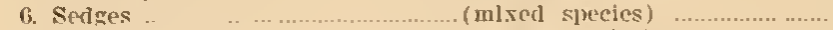 & $\ldots 75$ & .4871 & .605 & .266 & 6.13 & 22.90 & 3.20 & 14.06 & 53.71 & 1.063 & & 0.029 \\
\hline 7. Swanp Griss .............................. (mixed species) & 50 & .5254 & .295 & .177 & 3.32 & 24.63 & 2.86 & 14.13 & 5.5 .06 & 0.544 & 0.276 & \\
\hline 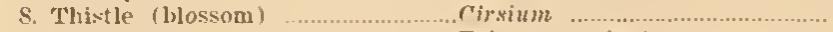 & $\ldots 30$ & .6553 & 1.185 & .351 & $6.3 \overline{5}$ & 25.19 & 2.58 & 11.00 & 54.58 & 1.430 & ......... & 0.410 \\
\hline 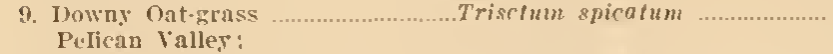 & $\ldots 65$ & .3809 & .495 & 166 & 6.71 & 28.61 & 1.98 & 11.13 & 51.57 & 0.832 & ......... & 0.044 \\
\hline 10. Sedges & 75 & .4253 & .530 & .205 & 5.37 & 26.70 & 2.17 & 12.91 & 52.82 & 0.928 & ........ & 0.027 \\
\hline 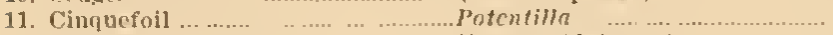 & ... 30 & .6786 & 1.030 & .494 & 6.92 & 26.49 & 3.28 & 12.00 & 51.30 & $1.4 \$ 2$ & ......... & 0.227 \\
\hline 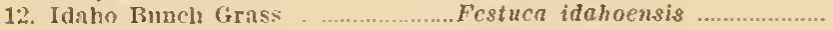 & $\ldots 80$ & .5041 & .685 & .203 & 7.52 & 26.24 & 3.49 & 13.88 & 48.87 & 1.100 & & 0.059 \\
\hline 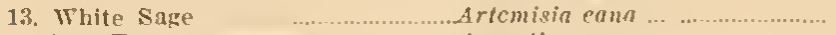 & 10 & .7338 & .530 & .263 & 5.58 & 23.52 & 5.64 & 14.94 & 50.02 & 1.978 & 0.286 & \\
\hline . & ... 70 & .4191 & .615 & .188 & 6.52 & 29.20 & 2.90 & 10.56 & 50.82 & 0.915 & ......... & 0.112 \\
\hline 15. Jupine & 50 & .6850 & $1 . \$ 35$ & .720 & 9.61 & 19.71 & 2.59 & 21.13 & 46.96 & 1.495 & ......... & 1.025 \\
\hline 16. Mountnin Tlmothy .....................Phlcum alpinum .... & 70 & .4956 & .675 & .243 & 6.29 & 29.50 & 2.34 & 10.44 & 51.37 & 1.083 & & 0.088 \\
\hline 17. June Grnss .............................ncterin cristafa &. .65 & .7105 & .780 & .108 & 7.22 & 30.11 & 4.23 & 14.00 & 44.41 & 1.439 & 0.0 .51 & ......... \\
\hline 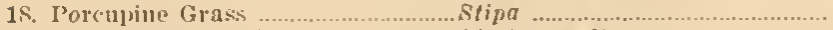 & .. 70 & .5107 & .415 & .143 & 6.09 & 30.39 & 2.34 & 13.69 & 47.49 & 0.766 & 0.160 & \\
\hline 19. Thistle (blossom) …..................... & .. 30 & .5829 & 1.385 & .382 & 9.22 & 25.76 & 3.37 & 8.75 & 52.90 & 1.273 & .......... & 0.695 \\
\hline 20. Onion Grass $\quad$.................................... & So & .3978 & .700 & .143 & 5.40 & 25.93 & 2.16 & 11.33 & 55.38 & 0.869 & & 0.129 \\
\hline 21. I3rome Grass: $\quad$ ……..................... Bromus & .80 & .6255 & .520 & . 148 & 7.45 & 29.46 & 3.63 & 13.25 & 46.21 & 0.959 & 0.186 & \\
\hline 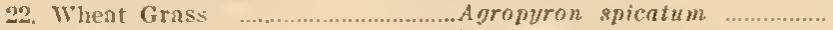 & .80 & .5149 & .710 & 121 & 6.25 & 28.39 & 3.34 & 13.56 & 48.46 & 1.124 & ......... & 0.101 \\
\hline $\begin{array}{l}\text { 23. Alkali Grass } \ldots \ldots \ldots \ldots \ldots \ldots \ldots \ldots \ldots \ldots \ldots \ldots \ldots \ldots \ldots \\
\text { Norris : }\end{array}$ & .. 70 & .7084 & .875 & .168 & 8.12 & 27.40 & 3.56 & 13.63 & 47.29 & 1.546 & ......... & 0.037 \\
\hline 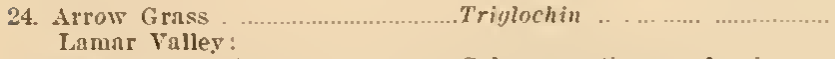 & 70 & .5595 & .970 & .253 & 11.67 & 25.82 & 2.30 & 14.25 & 45.96 & 1.220 & ......... & 0.309 \\
\hline 25. Mendow Pine Grass ..................... Calamagrostis canadensis & 70 & .4445 & .995 & .147 & 8.53 & 27.26 & 4.22 & 10.87 & 49.12 & 0.971 & ........ & 0.469 \\
\hline 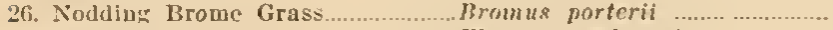 & .. 80 & .4807 & .780 & 297 & 6.99 & 30.39 & 2.28 & 8.19 & 52.15 & 1.050 & .......... & 0.211 \\
\hline ..... Elymus condensatus ................ & 20 & .4468 & .755 & .253 & 7.37 & 31.22 & 1.86 & 8.69 & 50.86 & 0.976 & .......... & 0.226 \\
\hline 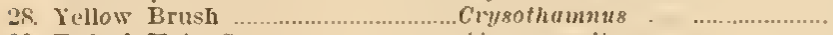 & 15 & .6339 & 1.890 & .340 & 7.47 & 21.59 & 2.63 & 12.81 & 55.50 & 1.364 & ........ & 1.140 \\
\hline 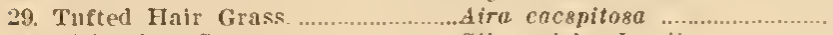 & 80 & .3619 & .935 & .161 & 8.16 & 28.14 & 1.55 & 7.81 & 54.34 & 0.790 & $\ldots \ldots . . .$. & 0.507 \\
\hline 30. Richardson Grass ............................. & 70 & .3403 & .5 .30 & .158 & 6.29 & 30.22 & 2.5 .5 & 6.75 & 54.19 & 0.742 & .......... & 0.128 \\
\hline 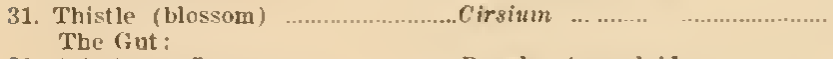 & ... 30 & .4702 & 1.290 & .863 & 10.03 & 28.28 & 4.03 & 7.56 & 50.10 & 1.026 & ......... & 0.734 \\
\hline 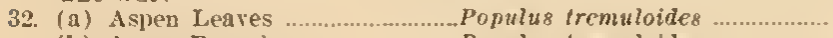 & 70 & .6381 & 1.300 & .402 & 5.94 & 15.18 & 6.03 & 15.06 & 57.79 & 1.393 & & 0.545 \\
\hline 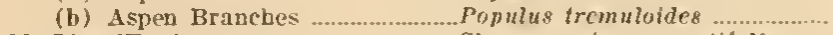 & 60 & .3488 & 1.110 & .235 & 3.61 & 28.77 & 4.97 & 5.05 & 57.60 & 0.762 & & 0.697 \\
\hline $\begin{array}{l}\text { 33. Flre Weed } \\
\text { Mammoth: }\end{array}$ & .. 35 & $.940^{2}$ & .640 & .509 & 6.08 & 19.14 & 2.21 & 12.86 & 59.71 & 1.181 & 0.399 & ......... \\
\hline 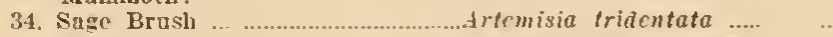 & 15 & .8147 & .365 & .257 & 6.26 & 27.03 & 8.33 & 9.86 & 48.52 & $0.6 \pi 3$ & 0.507 & \\
\hline 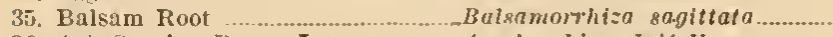 & ... 40 & 1.0168 & 2.425 & .495 & 15.65 & 18.50 & 3.32 & 7.63 & 54.87 & 2.220 & ......... & 1.222 \\
\hline 36. (a) Service Berry Leaves.............Amelanchicr alnifolia ............... & .. 60 & 1.1912 & 1.500 & .585 & 7.42 & 10.72 & 4.98 & 13.94 & 62.94 & 2.600 & ......... & 0.091 \\
\hline (b) Service Berry Branches.......... A nelanchier alnifolia ................. & .. 50 & .3745 & 1.470 & .246 & 3.47 & 28.72 & 1.42 & 5.63 & 60.76 & 0.819 & ......... & 1.026 \\
\hline 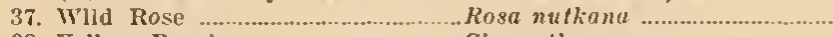 & 15 & .7744 & 1.470 & $.4 \$ 9$ & 6.16 & 17.74 & 3.90 & 8.19 & 64.01 & 1.690 & ......... & 0.5 .54 \\
\hline 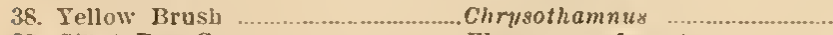 & .. 25 & .6232 & 1.000 & .183 & 6.40 & 20.97 & 11.07 & 9.44 & 52.12 & 1.360 & ......... & 0.269 \\
\hline $\begin{array}{l}\text { 39. Giant Rye Grass.............................. Elymus condengatus ............... } \\
\text { Game Ranch: }\end{array}$ & 20 & .4574 & .650 & .279 & 7.90 & 29.88 & 2.98 & 7.13 & 52.02 & 0.998 & ......... & 0.109 \\
\hline 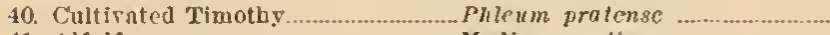 & 70 & .4679 & .530 & 167 & 7.41 & 20.06 & 2.72 & 6.69 & 54.12 & 0.978 & 0.020 & \\
\hline 41. Alfalfa & .. 90 & .4723 & 3.740 & .460 & 8.00 & 22.03 & 2.92 & 18.38 & 48.67 & 1.030 & & 3.182 \\
\hline 42. Fox Tail Barles ............................. Hordcum jubatum . & 10 & .4723 & .425 & .179 & 9.50 & 28.48 & 3.45 & 8.56 & 49.95 & 0.784 & 0.113 & .......... \\
\hline 43. Brome Grass .................................... Bromus inernis & ... 80 & .4658 & .495 & .203 & 7.73 & 28.72 & 2.13 & 11.13 & 50.29 & 0.013 & 0.048 & ......... \\
\hline $\begin{array}{l}\text { 44. Wheat Grass } \\
\text { Fan Feeds (collected in 0ct. 1930) }\end{array}$ & -80 & .4127 & .400 & .172 & 6.93 & 34.72 & 2.01 & 7.13 & 49.21 & 0.738 & 0.075 & .......... \\
\hline 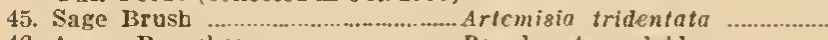 & ... 15 & .8399 & .709 & .387 & 4.25 & 20.72 & 12.58 & 14.06 & 46.45 & 1.3082 & 0.241 & \\
\hline 46. Aspen Branches ................................ Populus tremuloide & ... 60 & .8445 & 2.120 & .357 & 3.52 & 20.48 & 14.15 & 5.20 & 53.33 & 1.8436 & & 1.121 \\
\hline 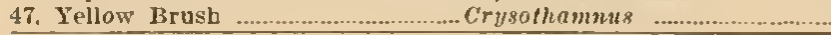 & $\ldots \quad 25$ & .5052 & .885 & .333 & 4.06 & 24.10 & 13.85 & 9.19 & 47.08 & 1.1029 & ............... & 0.287 \\
\hline
\end{tabular}




\section{MINERAL CONTENTS OF FORAGE PLANTS}

In co-operation with Mr. Edmund Burke, chemist of the Montana Agricultural Experiment Station, a study was made the summer of 1930 of the chemical contents of a number of forage plants, soils, and water on the elk range. The results of these analyses are given in Tables I, II, and III.

\section{TABLE II}

ANALYSIS OF SOILS ON ELK RANGE

\begin{tabular}{|c|c|c|c|}
\hline Sample & $\% \mathrm{I}$ & $\% \mathrm{CaO}$ & $\% \mathrm{~N}$ \\
\hline The Gut & .0903 & .628 & .331 \\
\hline 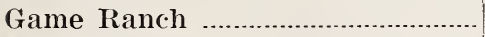 & .0914 & .804 & .121 \\
\hline Mammoth .. & .0931 & 1.244 & .149 \\
\hline Hayden Valley & .0663 & .225 & .229 \\
\hline Pelican Valley & .1160 & .308 & .305 \\
\hline Lamar Valley ....... & .0964 & .808 & .339 \\
\hline
\end{tabular}

\section{TABLE III}

ANALYSIS OF WATER FROM NATURAL LICKS ON ELK RANGE in parts per million

\begin{tabular}{|c|c|c|c|c|}
\hline & \multicolumn{2}{|c|}{ Buffalo Ranch Licks } & \multicolumn{2}{|c|}{ Upper Yellowstone } \\
\hline & No. 1 source & $\begin{array}{l}\text { No. } 2100 \text { feet } \\
\text { from source }\end{array}$ & $\begin{array}{l}\text { Bottom fed } \\
\text { spring }\end{array}$ & $\begin{array}{l}\text { Running water } \\
\text { spring } \\
100^{\prime} \text { distant }\end{array}$ \\
\hline $\mathrm{SO}_{2 . .}$ & 32.6 & 33.2 & 27.9 & 15.5 \\
\hline $\mathrm{Ca}$ & 2.3 & 1.8 & 3.4 & 11.0 \\
\hline $\mathrm{FeI}_{3} \mathrm{Al}_{2} \mathrm{O}_{3} \ldots \ldots \ldots$ & 2.6 & 2.4 & 0.6 & 1.0 \\
\hline Mg......................... & none & none & none & 4.5 \\
\hline $\mathrm{Na} . . . .$. & 306.6 & 300.2 & 35.0 & 15.7 \\
\hline $\mathrm{CO}_{3 \ldots}$ & 74.3 & 63.9 & 21.3 & 6.1 \\
\hline $\mathrm{HCO}_{3 . .}$ & 663.0 & 66.5 .0 & 55.0 & 80.0 \\
\hline Cl......... & 6.2 & 6.0 & 3.0 & 3.1 \\
\hline $\mathrm{SO}_{4} \ldots . .$. & trace & trace & none & none \\
\hline $\mathrm{P}_{2} \mathrm{O}_{5} \ldots$ & trace & trace & none & trace \\
\hline $\mathrm{NO}_{3} \ldots$ & none & none & none & trace \\
\hline
\end{tabular}

\section{Hypothetical Combinations}

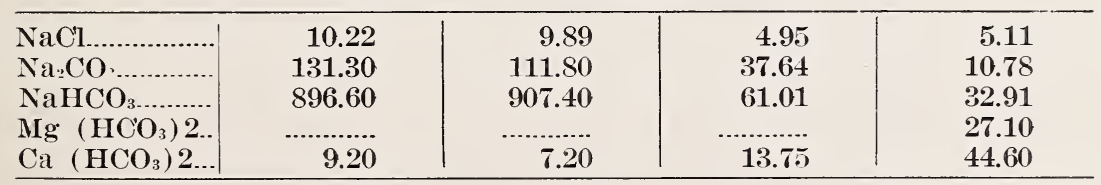


It has been shown by several investigators that the mineral contents of forage plants have a very important bearing on the health of grazing animals. Serious diseases result wherever grazing animals are forced to subsist on mineral deficient ranges. (References 1, 2, 3, 4, 5, and 6.) With an abundance of range the elk naturally would select plants best suited for their proper nourishment, but on a restricted range in a zone they did not select but were forced to use by the settlers' fences and domestic herds, the question has been whether or not the forage on the present elk ranges contained sufficient minerals.

No data are available on the proper diet for any of our wild ruminants and analogy must be made to the domestic ruminant which most closely approximates in food habits the wild animal in question until such time as studies of the wild animal can be completed. In the case of elk, the domestic cow undoubtedly is the closest approach in grazing habits. In making a comparison of food habits between elk and cattle allowances must be made for certain factors peculiar to each. Cattle are heavier than elk; should be kept in better winter condition; herds do not contain a number of aged animals. Elk must survive a period of scanty food supply in winter; young must subsist under very unfavorable conditions of food supply as calves are weaned on a scanty supply of food; the period of gestation also occurs during the winter, a part of which time the dam is undernourished, resulting in weakened offspring, abandonment of offspring, and in a few cases abortion, depending on the time and degree of undernourishment; bull elk require a large amount of calcium and phosphorus to grow a new set of antlers each year.

The amount of forage required per elk (based on meagre data), is about two-thirds of that required per head of domestic range cattle. The United States Forest Service (7) gives a figure of 9.69 forage acres per head per year for range cattle. For the particular range where this forage acre figure was secured 9.69 forage acres amounted to 27 surface acres. For elk the figures would be 6.46 forage acres or 18 surface acres for the type of summer range comparable to that used by elk in Yellowstone Park. T'he winter range at approximately 3,000 feet lower elevation is of a much lower quality and as its carrying capacity varies so much with the depth and condition of snow, no intelligent esti- 
mate can be made at this time of the number of acres required for elk.

No data are available on the mineral requirements of elk. In the literature previously cited (References $1,2,3,4,5$, and 6 ), are considerable data on the requirements for cattle but are not based on conditions sufficiently similar to those in Yellowstone Park to make a close comparison.

Table I shows the analysis made of a number of important forage plants collected from different parts of the range used by elk, at elevations ranging from 5,100 to 7,900 feet, Lamar Valley, Mammoth, and Game Ranch are parts of the winter range. Hayden Valley, Pelican Valley, Norris, and the Gut are parts of the summer range. The specimens taken from the Game Ranch are from good irrigated soil in fairly good tilth, at an elevation of 5,200 feet.

A comparison of the foregoing, with the examples cited by Scott, Reference 6, shows that the Yellowstone Park forage plants are somewhat higher in phosphorus (which from a survey of the literature cited seems to be the determining factor in mineral assimilation), than those on areas in Montana where cattle are unaffected with mineral deficiency diseases.

Elk have been observed chewing shed antlers. Bone chewing is one of the most characteristic symptoms of mineral deficiency diseases in cattle and with some observers of the elk herds has been associated with disease in these animals. An anlysis of an average elk antler shows the following composition:

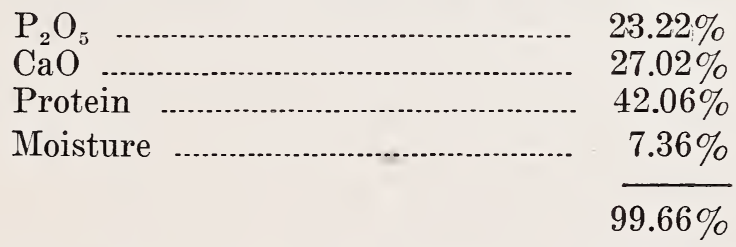

From this analysis and that in Table I it can safely be deduced that antler chewing by elk is due more to the presence of a high percentage of protein in the antler than to a lack of minerals in the forage.

It is interesting to note the total amount of calcium and phosphorus required to grow a new set of antlers each year. 
The average pair of antlers weighs about four pounds. The single tine of the yearling's weighs but a few ounces, while a large bull's antlers weigh $201 / 2$ pounds. The largest collected in Yellowstone Park weighs 36 pounds. For the 201/2 pound antlers 10.3 pounds of $\mathrm{P}_{2} \mathrm{O}_{5}$ and $\mathrm{CaO}$ were required.

From the foregoing and from lack of evidence to the contrary, it is concluded that the fluctuations in numbers of the Northern Yellowstone elk herds are not due to a mineral deficiency in the forage consumed by them.

References :

1. Mineral in Pastures, Orr and Scherbatoff.

2. Bulletin No. 344 Texas Agri. Ex. Sta.

3. Bulletin No. 299 Texas Agri. Ex. Sta.

4. Circular No. 122 Mont. Agri. Ex. Sta.

5. Bulletin No. 350 Wisconsin Agri. Ex. Sta.

6. Journal of Ag. Research Vol. 38, No. 2.

7. Bulletin No. 790 Dept. of Agri. Forest Service.

\section{EFFECTS OF FOXTAIL GRASS ON GAME ANIMALS}

NAMES: "Hordeum jubatem $L$., called squirrel-tail grass because of its soft brushlike spikes, is common on the Western states, where it is not infreqently a troublesome weed in alfalfa fields. This species is called foxtail in Wyoming, barley grass in Utah, and tickle grass in Nevada." (From Genera of Grasses of the United States B. P. I. Bulletin No. 772.)

Description: This grass grows from 12 to 24 inches in height in the locality of Yellowstone Park, in eompact bunches from a strong mass of roots, the bunches becoming larger each year as the plant grows older. It is a coarse grass with numerous flat leaves. The seeds are borne in a dense seed head breaking up into awnbearing spikelets, the awns being barbed their entire length. Their extremely sharp barbs all point to the tip, so that when once the awn starts to work in, the barbs prevent it from coming out until the action of the blood or juices of the body sufficiently dissolve the awn to separate the barb from it. A University of Nevada bulletin states that a single bunch of foxtail of about four inches in diameter will produce 2,000 seeds or 14,000 awns per plant. 


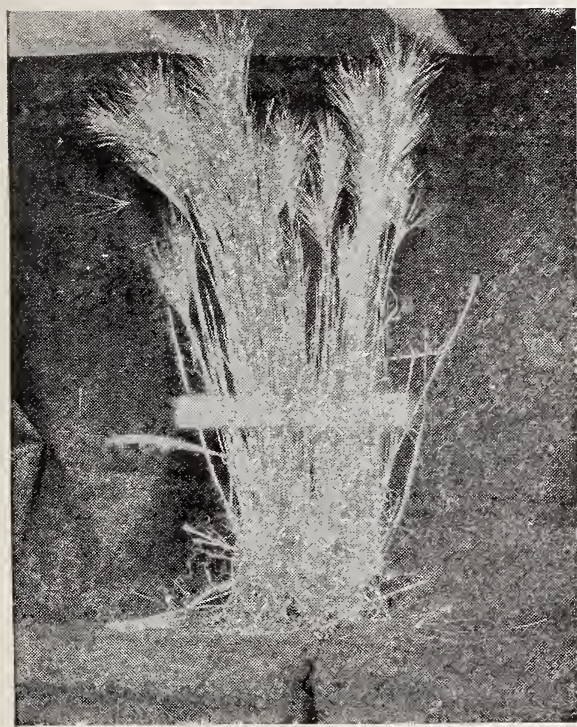

Bunch of Foxtail Grass.

If the plant ripens standing on the range, from $25 \%$ to $75 \%$ of the awns drop off, depending to a large extent on wind and snow; however, if cut when green and put in hay, practically all of the awns remain attached to the seed head.

Distribution: For the purpose of this study, only the area used by the Northern Yellowstone elk herd is considered.

Along the roads in moist sites, foxtail grows inside the Park to an elevation of about 6,500 feet. The cultivated ranches outside the Park are most heavily infested areas, the Garne Preservation Ranch being among the worst. The immediate vicinity of Mammoth is quite heavily infested.

Palatability: The U. S. Forest Service gives this grass a palatability of 40 for cattle and 10 for sheep on the Madison Forest, and 30 for eattle and 0 for sheep on the Helena Forest. For elk, antelope, and deer on the winter range where forage is scarce, the palatability of foxtail is about 70 . Where put up as hay, this is increased to nearly $100 \%$.

Damage: When foxtail is eaten by elk, deer, or antelope, the awns stick into the soft tissues of the mouth and because of the manner in which the awns are barbed they continue to work deeper into the tissues. The under side of the tongue, gum line and angle of jaws are favorable places for the awns to lodge and cause lesions. Infection of these mechanical injuries in the mouth with the organism Actinomyces necrophorus causes necrotic sores and the disease known as calf diphtheria or necrotic stomatitis, which, after breaking down the soft tissues, attacks the bones, causing morbid enlargement of the bone, or exostosis. The lesions produced by foxtail also open the way for other bacterial in- 
fection, such as the organisms of lumpy jaw and purulent abscesses.

Typical cases of the harmful effects of foxtail on game animals are cited in this report under the chapter on diseases.

Jackson Hole Elk: Mr. O. J. Murie diagnosed necrotic stomatitis in 70 out of 193 post-mortems the winter of 1928-1929, and ascribed to foxtail grass the mechanical injury which allowed the disease to start. Ref. Biennial Rep. Wyo. Fish and Game Com. 27-28, also Jor. of Mam. Vol. 2, No. 2.

Conclusions and Recommendations: Foxtail is the primary cause of many of the losses in elk, deer, and antelope, and should be eradicated as completely as possible on the winter range. No hay should be fed to game animals that contains foxtail.

All of the cultivated lands acquired in the elk range should be immediately seeded to pasture grasses such as the various bromes, redtop, blue grass, et cetera. If cultivated land is allowed to lie for two or three years, fanweed and foxtail will crowd out the timothy or other tame hay grasses.

\section{RELATION OF HEAVY USE OF RANGE TO SPREAD OF PARASITES AND DISEASES IN ANIMALS}

Identification of the parasites infecting the game animals of this region has been made by Dr. Maurice C. Hall, of the Bureau of Animal Industry, who also furnished a "List of References to Original Literature," from which literature most of the following information on the life histories of the various parasites has been taken.

Parasites infecting the game animals of this region and dealt with in this study are:

\section{Antelope :}

The intestinal worms Ostertagi ostertagi and Nematodirus antilocaprae: lung worm-Dictyocaulus $s p$.

Deer:

The intestinal worms, Nematodes; Nematodirus fillicollis, N. spathiger, O. osteragi. Cestodes; Moneizia sp., Thysanosoma actiniodies, Lung worm, Protostrongylus macrotis. Encysted larvae, Cysticercus ovis. 
Elk:

The lung worm Dictyocaulus hadweni, and a parasite infesting the heart muscle Sarcocystis miescheriana.

Ostertagi ostertagi. Ref. p. 520 and 523, Special Report Diseases of Cattle, U. S. D. A. 1923.

"The life history of the encysted stomach worm (O. ostertagi) is not known in detail, but is undoubtedly very much the same as that of the twisted stomach worm (Haemonchus contortus).

"Cattle become infected with these parasites by grazing on pastures on which infected cattle, sheep, or goats have grazed and scattered their droppings. The worms in the stomach produce a multitude of eggs of microscopic size which pass out of the body in the feces. In warm weather these eggs hatch in a few hours. If the temperature is below 40 degrees $\mathrm{F}$., they remain dormant, and if below freezing, they soon die. The eggs are also killed by dryness; moisture, on the other hand, favoring their development. The larvae which hatch from the eggs are microscopic in size, and like the eggs, are at first and until they develop to a certain stage, very susceptible to freezing and drying. In very warm weather the larvae complete their development, so far as they are able to outside the body, in two or three days. In cooler weather the time required for this development is longer, and at temperatures below 70 degrees $F$., ten days to several weeks may be necessary. The larvae are then ready to be taken into the body. The eggs and early stages of the larvae apparently do not develop if swallowed, and only the completed larval stage seems to be infectious. In this stage the larvae migrate up grass stalks or other objects, showing activity whenever the air is saturated with moisture; that is, driving rains, fogs, and dews. When the air becomes dry and the moisture evaporates from the grass the young worms cease their activity, resuming their migrations when the air again becomes overladen with moisture. Larvae which have developed to the infectious stage, unlike the eggs and early larval stages, are able to survive long periods of freezing and drying. In two weeks to a month after the embryos are swallowed they reach maturity and begin producing eggs.",

It is significant that this parasite has been found in this region only in the antelope and deer, which are the only game 
animals remaining on the low ranges during the summer, or where conditions are favorable for the larvae to reach the infectious stage.

The following is taken from the Journal of Parasitology: Summary of Life History of the Nematodirus filicollis: Vol. 8, (2) September, 1915, Boulenger.

“1. The eggs of Nematodirus fillicollis when laid contain an embryo with seven or eight cells. They pass out of the infested host with the faeces.

“2. Even under favorable conditions development takes place slowly and the embryos are not ready to hatch until 24-28 days have elapsed. In their early stages the embryos are not able to withstand desiccation and are killed if frozen or subjected to high temperatures.

" 3 . Whilst still within the egg-shell the embryo undergoes two ecdyses and when ready to hatch is enclosed in a tightly fitting sheath formed by the incompletely cast skin of the second moult; the larvae on liberation from the egg-shell are therefore in a more advanced condition than those of most other Strongylids (e. g., Haemonchus or Anchylostoma) and are in a stage comparable with that reached by the latter at the end of their period of free existence.

"4. T'he sheathed larvae are often retained for a long time within the egg-shells and both in this position and after hatching can resist complete desiccation for considerable periods (twenty months or even longer); when dried they are able to withstand freezing as well as temperatures much above those likely to be met with in the open.

" 5 . The free larvae will live for a considerable time in water. They possess well-developed migratory instincts and climb vertival surfaces, such as grass stems and blades, and the glass walls of the vessels in which they are kept.

"6. The sheaths are cast off by the larvae when these are subjected to temperatures approximately the blood-temperature of the host; completion of the second moult occasionally also takes place at laboratory temperatures under certain abnormal conditions.

"7. No infection experiments were made on sheep, but other evidence shows that these animals must become infected by swallowing the sheathed larvae, either when free or whilst still enclosed in the egg-shells. 
"8. A number of young stages of the parasite were met with in the intestines of sheep, the smallest of these being only little more advanced in structure than the larvae just after ecdysis.

Dr. Hall states that in the case of the $N$. antilocaprac "we presume that the life history is similar to that of $N$. fillicollis of the sheep which was described by Boulenger in 1915." By reference to paragraphs number four and five of the foregoing it will be noted that these parasites are particularly adapted to propagation by grazing animals.

Nematodirus spathiger. Ref. Farmers' Bulletin No. 1330, U. S. D. A., p. 31.

"The eggs produced by the female worm pass out in the feces and an embryo develops in the . . . larva hatches under the influences of alternating moistening and drying or of temperature of 75 degrees F. to 90 degrees F. . . . the ensheathed larva then ascends blades of grass under favorable conditions of temperature and moisture, and is taken in by sheep as they feed. These larvae are very resistant to cold and drying, and have. also been found to live in water for eleven months. In the intestine of the sheep the larvae develop to adult worms."

Protostrongylus macrotis. It appears that the life history of lung worm is similar to that of the sheep lung worm Dictyocaulus filaria.

Dictyocaulus hadweni. The elk lung worm's life history is doubtless similar to that of the sheep lung worm D. filaria and the following is quoted, somewhat modified, from Cuberlet in the American Vet. Medical Association Journal, Vol. 55, September, 1919:

"Life history summary of $D$. filaria.

"1. Eggs are extruded into the air passages of the lungs, pass with mucus to alimentary tract, leave animal with the feces.

"2. Embryos under favorable conditions of moisture molt and develop protective sheaths in eight to ten days.

"3. The ensheathed embryos leave the feces or soil when the air becomes saturated with moisture and migrate on to blades of grass or other vegetation where they may be ingested by grazing animals, in which, if they are suitable hosts, complete their development. 
"4. In the lung the worms cause hemorrhages and congestion sometimes resulting in pneumonia.

"5. Mode of gaining entrance to body of host is particularly adapted to grazing animals."

Moniezia sp. A specific identification of this parasite has not been made, but it is probably closely related to $M$. alba. The larval forms and life history is unknown but as the ova pass with the feces to the ground, reinfection no doubt occurs either through the forage or drinking water.

Thysanosoma actinioides. The fringed tapeworm of domestic sheep, found in the deer of the Park and in one specimen of moose. Infection is probably from ingesting ensheathed larvae with the forage.

Cysticercus ovis. This is the larval form of the tapeworm Taenia ovis of which the coyote is host for the mature worm. The ova from the mature worm pass from the coyote to the ground through the feces, infecting the forage much the same as previously described. The larvae ingested by the deer pierce the walls of the digestive system, are taken up by the blood or lymph stream, and are deposited in the muscles, where they become encysted and remain for the life of the deer. Coyotes become infected by eating the flesh of the infected deer.

Connection with heavy use of range: It will be noted that in the life history of these parasites that after reaching the larval stage it requires a great deal of freezing and dryness to destroy the viability of the larvae and that they have, at this stage, migrated from the ground to the tips of grass and other vegetation. With heavy use of the range such as occurs on the winter range in this region, conditions are favorable for a large percentage of the larvae to reach their preferred hosts. This no doubt takes place in the early part of the winter or somewhat late in the spring.

Concentration of animals on the range favors the parasites and they tend to build up in numbers to a dangerous point. An interesting point in this connection is the fact that practically. all of the deer in the vicinity of Mammoth, when the concentration is heavy year after year, are infected with lung worms and tapeworms of both species named in the foregoing. The fringed tapeworm $T$. actinioidies has but recently been discovered in the deer, 
indicating that they have just lately become infested with this parasite.

Experiments with domestic sheep have shown that a few head in a pasture will rid themselves of the lung worm while a larger number will remain infected year after year.

Sarcocystis. Professor Scott, in the Journal of Parasitology Vol. XVI, No. 3, March, 1930, writes: "In the experience of the writer, lambs raised under crowded conditions become more heavily infected than those that have a wider range whether in pasture, dry lot, or screened cage. Considering all the facts there is scarcely any doubt that food contamination is the usual method by which Sarcosporidia are transmitted to new hosts."

Actinomycosis (lumpy jaw). The disease of lumpy jaw is caused by an organism known as Actinomyces bovis. Dr. Buchanan in his book "Agrieultural and Industrial Bacterioligy," p. 368, states: “. . . are very abundant in the soil." The U. S. D. A. Special Report on Diseases of Cattle, p. 440, states: "The ray fungus (Actinomyces) is found in native vegetated grasses, on the awns of barley, the spears of oats, and on other grains."

Actinomyces necrophorus is the causative organism of Necrotic stomatitis (calf diphtheria), and a number of other diseases. Hutyra and Marek in their Pathology and Therapeutics of Domestic Animals (P. 444, Vol. 1), state: "Natural infection may probably be explained by stating that the bacillus (actinomyces) necrophorus, which is very extensively distributed in nature, is among others frequently contained in the feces of herbivorous animals, and owing to its anaerobic character remains alive for a long time on the dirty floors of damp stables, in musty food and straw ..."

Obviously an overerowded range would tend to be favorable to the contraction and spread of these diseases.

It has long been known that concentration of game animals tends to produce and develop disease in them but the specific causes have not been learned. From the foregoing, taken largely from the studies of domestic sheep and cattle, it can be reasoned that, with our small amount of specific knowledge of the diseases of game animals that a greater margin in the carrying capacity of the game animal ranges should be provided for than in ranges used solely by domestic stock. 
The need for intensive study of diseases of game animals is also obvious, as too close an analogy to domestic animals should not be accepted.

\section{WEED PESTS ON WINTER ELK RANGE}

It is interesting to note that of 24 non-forage weeds in the Park 11 have been introduced here indirectly from Europe, two from Asia, one from the Pacific Coast, one from the Central States, one is an escape from cultivation and only eight are native species, and of these eight, two are probably non-native to Yellowstone.

The following is by no means a complete list of the weeds of the Park, but does indicate the importance that the non-forage plants are assuming in our range problems:

Salsola pestifer-tumbling weed. Introduced in the United States from Asia. Very drouth resistant. Easily carried with seeds of forage crops. Readily destroyed on cultivated ground. Is becoming a serious pest in the Yellowstone region.

Sophia incisa-tansy mustard. Introduced from $\mathrm{Pa}$ cific Coast. Carried in seeds of forage and grain crops. Very prevalent in cultivated fields.

Tragopogon pratensis-oyster plant. Escaped from cultivation.

Bursa bursa-pastoris-shepherd's purse. Introduced from Europe. Easily destroyed by mowing or cultivation. Distributed in seed of other plants.

Linaria linaria-toad flax. Introduced from Europe and planted in flower gardens as an ornamental plant. Escaped cultivation and now common in poorly kept fields and waste places.

Solanum triflorum-wild tomato. Introduced in Yellowstone Park. Berries poisonous.

Lygodesmia juncea-devil's shoestring. Non-native to Yellowstone Park. Somewhat difficult to control.

Polygonum convolvulus-bindweed. Introduced from Europe. A common nuisance in grain fields.

Thlaspi arvense-fanweed. Introduced from Europe. Carried in seeds of forage and grain crops. In a very 
few years this weed will take possession of a field. Considered the worst weed pest in the Western states. Widely distributed on the elk range.

Lepidium apetalum-pepper grass. Non-native to Yellowstone Park. Seeds are carried by animals, birds and man. Not extremely harmful.

Plantago major-plaintain. Native. Non-forage. Strong competition to grasses on heavily grazed areas.

Rumex crispus-curled dock. Introduced from Europe, now carried in impure seed of alfalfa, timothy, etc.

Helianthus annuus -wild sunflower. Introduced in Montana from Central states. Very common now in Yellowstone. Certain aesthetic value.

Hordeum jubatum -foxtail barley. Native. Of little value as forage. Very harmful to animals when eaten as hay.

Bromus tectorum-cheat grass. Introduced from Europe. Has taken possession of hundreds of thousands of aeres of range lands in the Western states. Eradication especially difficult because of uneven germination of seed. Of little value as forage.

Taraxacum officinale-dandelion. Introduced from Europe. Eradication practically impossible. Of some value as an early spring forage crop. Of some value as a producer of nectar and pollen for bees.

Brassica arvensis-common field mustard. Introduced from Europe and now very common in the fields throughout the United States. Seeds are commonly mixed with grain and grass seed. Eradication very difficult.

Chenopodium album-lamb's quarters. Introduced from Europe and now one of the commonest weeds in the United States. Carried with crop seeds. Not particularly harmful except in cultivated fields.

Alsine media-starwort. Introduced from Europe. An indicator of overgrazing on the range.

Chrysothamnus (sp?) -yellow brush. Native. Young plants in abundance on the range an indicator of overgrazing.

Agropyron smithii-western wheat-grass. Native. Prodominance of this species on range indicates overgrazing. 
Gutierrezia (sp?)—snake weed. Native. Overgrazing indicator.

Hymenophysa pubescens-white top. Introduced from T'urkestan in comparatively recent years. One of the most serious weed pests wherever it has gained a foothold.

Cirsium arvense-Canada thistle. Introduced from Europe by way of Canada. Serious pest very difficult to eradicate.

Many of these obnoxious weeds have evidently become distributed over the Park with hay and oats. At the Game ranch and the Gardiner field no doubt the seed of the forage and grain species planted was mixed with considerable weed seeds. Of the most harmful species to the winter game range cheat grass is the worst. This grass has taken possession of and rendered valueless several hundred thousand acres of good range land in many parts of Montana. It has a good foothold in the Park, particularly around Gardiner and Nammoth where it is steadily encroaching on the range lands.

Cultivation and overgrazing are two factors largely responsible for the introduction and spread of non-forage plants on the winter elk range.

Suggestions for the control of some of the worst of these weed pests are included in this report under the heading Range Management.

\section{RANGE ILANAGEMENT}

Present condition of range and suggested means for improvement. Inside Park. Conditions are satisfactory on the summer range, except that more salting might well be done. The salt ground established in Hayden Valley in 1929 is well located and if kept supplied with salt would attract numbers of elk to a point where tourists would see them.

The winter range, as has been mentioned before, has deteriorated fully 50 per cent since 1914 due to overgrazing and drouth. One more than half of the range sheet erosion has taken place to a depth of one to two inches which in soil of this type is a serious loss. In some few minor areas gully erosion has begun. 
A good growth of porcupine grass (Stipa sp?) on this range in the spring of 1931 is a good indicator that overgrazing has not gone to the extent that the native forage grasses will not come back if given a chance.

The invasion of rabbit brush (or yellow bush) Chrysothamnus, and other weed overgrazing indicators, however, indicate the seriousness of the extent of over-use.

On some of the lower range, particularly in the vicinity of Gardiner, military grass, Bromus tectorum, is a real menace. Some quadrats were established last fall to determine the rate this pest is spreading on the range. Unless, in the next two or three years it is determined that this grass is losing headway steps should be taken toward its eradication.

All browse species are heavily overgrazed by elk and will eventually disappear from the range unless improvement is shown in the next few years. Even the sagebrush on the Mammoth to Gardiner section is nearly all dead, due in some measure to browsing by antelope.

It is impracticable to herd elk from the overgrazed areas but on that part of the winter range west of Lamar Canyon to the Yellowstone River along Specimen ridge which is much used by buffalo early in the spring when the most damage is done, it is practicable to herd the buffalo on some other area.

All commercially used horses should also be kept from the elk winter range, if possible from a park administration standpoint.

Artificial reseeding is probably the only practicable method whereby this range can be quickly brought back to a high forage producing eapacity. A Government bulletin, U. S. D. A. Circular No. 178, Artificial Reseeding on Western Mountain Range Lands, August, 1931, is now available as a guide for this kind of work.

\section{Range Outside Park}

It seems clearly indicated that steps should immediately be taken to put all of this range on the basis of its highest forage producing capacity, through artificial reseeding, irrigation of certain areas, and sagebrush removal on some areas. 
All of the cultivable lands should be reseeded to pasture grasses. The forage on these areas could be increased 500 to $1000 \%$.

All of the irrigable lands along already existing ditches should be irrigated. This should result in a forage increase on such areas of at least $100 \%$.

Areas of especially rich soil carrying a heavy stand of sagebrush, with the resulting low stand of forage plants, could well be cleared of sagebrush. Such an area lies immediately south of the Game Preservation Company ranch. Experiments at the Colorado Agricultural College show that on some areas desirable forage plants increased 160 to 262 per cent after the removal of sagebrush, and with rodent control 344 to 1445 per cent. Ref. Bul. No. 308-A Colo. Agri. Ex. Sta. November 1931.

Extensive salting on the winter range outside the Park would tend to retard the return spring migration and give the overgrazed range inside the Park a better chance to improve. This might tend, too, to eause more elk to summer outside the Park on Crevice, Bear, Trail, Bassett and Cedar Creeks. Some salting was done in 1927 and 1928 which indicated the practicability of this measure.

Artificial feeding seems undesirable except as an emergency measure, as in 1919-20, to prevent starvation on a large scale. The Slough Creek ranches might well be continued a few years longer until the winter range land purchase program has further advanced and the winter range has improved.

Following are some of the reasons why artificial feeding is not recommended:

(1) The feeding at Gardiner and the Game Ranch attracts the elk from the Park early in the season. In 1930 elk were on the Game Ranch October 11 and in 1931 seventy-five elk were there on September 28 and 200 elk on September 30.

(2) Under present hunting laws it is very undesirable to attract elk from the Park early in the fall season.

(3) Elk quickly become dependent on feeding and do no rustling for themselves, thus becoming "paupers:"

(4) Congestion on the feeding grounds favors the transmission of diseases, not only amongst the elk but the deer and 
antelope also as these animals frequent the elk feeding grounds. The close proximity of elk, deer, antelope and horses on such a small area as a feeding ground day after day is an unnatural relationship, unhygienic and is kound to show unfavorable results to, at least, some of the species suoner or later.

(5) The artificially fed animals are in a poorer physical condition in the spring than the ones who rustle all winter. This is especially noticeable in the deer herd at Mammoth where the deer are fed hay and cottonseed cake all winter. The fawns especially are in much poorer condition than the fawns seen away from Mammoth, who have not been fed at all.

(6) Foxtail grass (Hordeum jubatum) is present in practically all of the hay produced in the Western states and it has been shown that this grass is extremely harmful to all species of hay eating animals. It seems particularly harmful to elk and deer, probably because the mouth tissues of these animals are more tender than in other animals. The disease of necrotic stomatitis results from bacterial infection of the lesions produced by foxtail grass. Probably also Staphylococcus pyogenes infections many times result from the same cause.

Scientific range management, while badly needed on the elk range, is impracticable because of the peculiar nature of the animals using the area. Elk cannot be herded so must be allowed to follow their own fancies in roaming the country. Artificial influences, such as hunting, salting, etc., are not sufficient to effect the desired distribution on the range. Fences are not practicable except to a very limited extent, such as trapping corrals.

Regulation of seasonal use, rotation and deferred grazing, so essential to proper range management, are obviously impracticable with wild grazing animals on a large area and it is also obvious that to provide sufficient forage on the particular areas naturally selected by elk that other areas in the same range will be underutilized. Compared to the forage actually consumed, elk should have a larger acreage than cattle to allow for the uncontrollable habits of the elk. 


\section{CONTROL OF WEED PESTS}

Mr. Talbot, weed expert of the Bureau of Plant Industry, made a field examination of some of the weed infested areas of the elk winter range in 1931. His findings are quoted:

\section{Weed Problems of Yellowstone National Park}

\section{A Preliminary Statement}

"Most of the information here recorded was obtained on July 15, 1931, during a preliminary field examination of certain key areas in the northern portion of the Park, in the vicinity of Mammoth Hot Springs, Wyoming. The trip was made at the invitation of the National Park Service, through Mr. George F. Baggley, chief ranger of Yellowstone National Park, and of Mr. William M. Rush, in charge of the Yellowstone elk study, whose various courtesies and careful planning made possible the seeing of representative samples of an unusually large area in the limited time at our disposal. The inspection party included Mr. Joseph Dixon, field naturalist, National Park Service, and Mr. Almer P. Nelson, in charge of the Elk Refuge, Biological Survey, Jackson, Wyoming, to whom I am indebted for transportation from Jackson to the Park.

"The weed problems brought to our attention by officials of Yellowstone National Park concern two classes of land: hay lands and winter range for game. The hay lands yield hay for winter feeding of game animals, chiefly elk, when the supply of native forage is inadequate. The winter range consists chiefly of comparatively open foothills which provide winter grazing grounds for the northern Yellowstone elk herd when winter snows drive the animals down from their summer range in the higher mountains. Certain portions of the winter range are used also by the buffalo herd, by deer, and by the small herd of antelope.

\section{Weed Control in Hay Lands}

"The hay lands with which this report is concerned consist of a series of separate tracts extending along the valley of the Yellowstone River for several miles below Gardiner, Montana, the north entrance to the Park. A few fields lie just above Gardiner along the road to Park headquarters (Mammoth Hot Springs), five miles to the 
southward in Wyoming. Several of the alfalfa fields and tracts of potential hay land, recently acquired by the National Park Service, are located in a proposed addition to the Park.

"The alfalfa fields lie at the approximate elevations of 5,300 and 5,400 feet, in a region whose mean annual precipitation is probably about 15 inches. Irrigation is necessary for the production of hay. Some poorly levelled fields have been inadequately watered. In others the stand of alfalfa is very old. In most of the meadows examined, the stand of alfalfa is thin and uneven, the yield of hay is low, and weeds are abundant.

"The oldest fields in which the stand of alfalfa is very thin are badly infested with downy chess, Bromus tectorum, locally known as 'downy brome-grass,' with foxtail barley, Hordeum jubatum, and with dandelion, Kentucky bluegrass, and other weeds.

"In one newly seeded field in which only a poor stand of alfalfa was obtained, Frenchweed, Thlaspi arvense, locally known as 'fanweed,' was abundant, Canada thistle, Cirsium arvense, had smothered all other vegetation on a small area an acre or two in extent, and Mr. Rush called our attention especially to several small patches of a new troublesome weed which proved to be Hymenophysa pubescens, a plant that is often confused with perennial peppergrass, Lepidium draba, in southern Colorado where both plants are locally known as 'whiteweed.'

"Park officials directly concerned with game management, particularly elk management, are especially desirous of reducing the amount of foxtail barley in hay to the lowest practicable point because of the injury to elk from feeding on 'foxtail hay.' Precisely the same problem confronts the Biological Survey at the Winter Elk Refuge in Jackson Hole, the location of our experiment on the control of foxtail barley in Wyoming meadows, an experiment undertaken jointly by the Bureau of Plant Industry and the Biological Survey. It will be recalled that mechanical injuries and disease losses resulting from the sharp seeds of foxtail barley, and possibly of other plants including downy chess, have been reported by Mr. O. J. Murie of the Biological Survey, in charge of the study of the southern Yellowstone elk herd, and later by Mr. William M. Rush, in charge of a similar study of the northern Yellowstone herd for the National Park Service, the Forest Service, and the Montana Game 
Department. The injuries appear to result chiefly, if not entirely, from the weeds fed in hay. Neither study has yielded any clear evidence of injury to elk from grazing on the open range.

"Plowing up and reseeding of all irrigated meadows whose stands of alfalfa are thin and weedy would appear to be advisable from the standpoint of weed control and of increased yield of hay. Preliminary observations on our experiment in Jackson Hole indicate that such weeds as foxtail barley and downy chess are least abundant in uniformly thick, vigorous stands of alfalfa.

"Immediate cutting of the patches of Canada thistle was urged, as the plant was beginning to bloom at the time of our examination, and it is likely that viable seeds are produced in this region. In any further cultivation of this field, separate cultivation of the thistle patches was advised, to avoid needless scattering of the weed by root fragments dragged about by tillage implements. Mr. Nelson and I were of the opinion that it would be advisable to plow this field immediately after hay harvest and to cultivate it with a 'duckfoot' cultivator or some similar implement at intervals of no longer than one week until freezing weather. This intensive fallowing would weaken the Canada thistle and should greatly thin the patches of 'whiteweed,' as many of the plants appeared to be young and not yet deeply rooted. An examination next spring should show whether these destructive perennial weeds have been cleaned up sufficiently to warrant reseeding of the alfalfa at that time, or whether another season of fallowing would be advisable.

"It was explained to the Park officials that the making of detailed recommendations regarding reseeding of alfalfa meadows did not fall within the scope of my weed work, and that such advice, if later desired from this Bureau, would come from our Division of Forage Crops and Diseases.

"Mr. Nelson called attention to the possible employment of the 'corrugation' system of irrigating on certain inadequately watered alfalfa fields. T'his system is rather widely employed in several states for the most efficient use of a rather scanty water supply, especially on fields having uneven surfaces, according to Mr. H. L. Westover, our alfalfa specialist of the Division of Forage Crops and Diseases. 


\section{Treatment of Weedy Abandoned Fields}

"A few fields previously cultivated but later abandoned, have been overrun by weeds, especially downy chess which occurs in dense patches. These fields could be irrigated. For several reasons, however, including the need for construction of expensive ditches, the Park Service prefers that these non-productive, eroding areas be converted into pastures, if reseeding to pasture grasses is possible.

"The best treatment of these abandoned fields could not be determined from our short examination. No definite recommendations were offered regarding this problem, which relates very closely to the work of other divisions of the Bureau of Plant Industry, and to the rangeresearch work of the Forest Service. My offhand, personal opinion was that the chances were none too bright for the establishment and survival of satisfactory stands of any of the standard forage plants on these fields where the estimated rainfall is only about 15 inches. Crested wheatgrass and brome, plants that have given good results in other regions of limited rainfall, are introduced plants; and, as I understand it, the policy of the National Park Service favors the use of native plants as far as practicable Park management permits.

"In view of the uncertain factors involved, Mr. Nelson and I were of the opinion that any initial attempts to reseed these marginal lands, without irrigation, should be restricted to small areas on which the selected plants could be tried out experimentally before any extensive reseeding program was undertaken.

\section{Weed Control and Range Improvement on Winter Range for Game}

"According to Mr. Rush, the main winter range of the northern Yellowstone elk herd comprises roughly a section of the valley of the Yellowstone River and its tributaries, 40 to 50 miles in length, extending in a southeasterly direction from Yankee Jim Canyon, 17 miles north of Gardiner, Montana, at an elevation of about 5,000 feet, to approximately the 7,500 foot contour. During especially severe winters, when most of the forage at the higher elevations is covered with snow, even on slopes of southern exposure, the elk drift down the Yellowstone Valley several miles beyond Yankee Jim Canyon. 
"The upper part of the winter range lies in the Park. The lower portion north of Gardiner is located partly in the Absaroka National Forest and partly in the Gallatin National Forest. A proposed addition to Yellowstone Park will enlarge the winter range that is under the jurisdiction of the National Park Service.

"In an automobile trip of approximately 100 miles through the winter range and in short side trips afoot, Mr. Rush showed us typical examples of range use varying from unquestioned overgrazing in the valleys and on the foothills north and northwest of Mammoth Hot Springs, to lightly used areas at the higher elevations. The lower foothills, grazed in the past by domestic stock as well as by game, have been subjected to the heaviest grazing. On certain areas near Gardiner, Montana, overgrazing was clearly indicated by such signs as active erosion, a decrease in the stand of the best forage plants, and an increase in abundance of inferior forage plants and of range weeds. Downy chess, a very inferior, almost worthless grass, has overrun large acreages on the lower foothills. Definite information is lacking, relating to the possible further spread of this range weed onto higher slopes, and to the extent to which it may be controlled by methods applicable to rough range lands. At the other extreme, at higher elevations near the lower margin of summer range, large areas appeared to be in good condition. Certain intervening areas grazed at some time of the year by buffalo, horses, and elk, are slightly overgrazed, in the opinion of Mr. Rush, whose close observations for several rears reveal the beginning of range damage.

"The supply of winter range for game is regarded as inadequate, although MIr. Rush is of the opinion that portions of the winter range previously damaged by overgrazing in the vicinity of Gardiner, Montana, have improved as a result of better cooperative management during the past few years. The objective sought is a system of game management and range management by which range damage may be reduced to the minimum and feeding of elk will be made unnecessary except during occasional emergency periods. In working toward this objective, the National Park Service is confronted with such questions as the following:

"T'o what extent can the condition of weedy overgrazed areas of winter range be improved without material reduction in size of the elk herd? 
"To what extent can the rapid spread of Bromus tectorum be checked and its replacement by good forage plants encouraged, by practicable management methods?

"What are these methods?

"How rapidly may improvement be expected?

"What changes, if any, in the practical management of game and range would promote a maximum yield of range forage year after year without serious range damage?

"In connection with his elk study, which has been in progress between two and three years, Mr. Rush has established fenced and unfenced plots for comparison of grazed and ungrazed areas. He has developed a mass of valuable data bearing on the essential questions at issue, questions that have opened up a complex research problem, certain phases of which would require years of intensive field study. The life-history study of elk, by Messrs. Murie and Rush, is approaching completion. The next step, therefore, would appear to be consideration of an enlargement of the elk study to permit the placing of greater emphasis on game-range research, a project to be pursued for a period of five to ten years.

"The national importance of the game herds and game ranges of Yellowstone National Park would seem amply to justify such a comprehensive project, to be conducted by the National Park Service in cooperation with other interested agencies. As this work with the northern elk herd has been developed in conjunction with the research program conducted by the Biological Survey on the southern herd, and since portions of the winter range for game are located on the Absaroka and Gallatin National Forests, the Biological Survey and the Forest Service are directly concerned in the problem. As the States of Montana and Wyoming are responsible for important features in the protection and administration of the elk herds, they also are vitally interested in the development of sound research as a basis for the most intelligent and efficient handling of the herds."

M. W. Talbot, In Charge, Weed Investigations.

U. S. Department of Agriculture,

Bureau of Plant Industry,

Division of Botany,

Washington, D. C., August 15, 1931. 


\section{SALTING}

The following work has been done, on none of which has there been sufficient follow up to base definite conclusions.

Ten salt logs, constructed for the main purpose of controlling the deer bot-fly larvae infestations were established in the spring of 1930 from April 10 to May 2.

Five additional salt grounds were established in the spring of 1931.

One salt ground was established near Alum Creek in Hayden Valley, August 9, 1929.

One thousand pounds of block salt were placed on the winter range outside the Park in 1927 by the Forest Service and State Game Department. Some of this salt (probably 30\%) was consumed by domestic stock.

The following notes are indicative of the use of these salt grounds by game animals :

May 30, 1930-Salt all consumed from Alum Creek salt grounds. Soil and grass pawed by elk in search for more salt.

June 16-Elk and deer are using Salt Ground No. 6.

July 20-Six antelope seen eating salt from No. 5.

October 18-No. 9 much used by deer and elk. No. 6 much used by deer and antelope.

April 1, 1931-No. 9 empty of salt; fresh tracks of elk and deer around grounds.

April 17-No. 6 empty of salt.

August 5-Little Buffalo grounds empty of salt-not being used.

August 6-No. 9 empty-fresh deer tracks.

August 6-Cottonwood salt troughs empty of salt.

The two salt grounds established for the buffalo herd on which some 4000 pounds of salt are placed yearly are much frequented by the elk.

Analysis of the water from natural elk licks show from 4.95 to 10.22 parts per million of salt. The artificial salt requirement per day for a domestic range cow is about one and one-third ounces on comparable mountain ranges. An animal to get this amount of salt from a natural lick such as are in the Park would 
have to drink in excess of 1000 gallons of water per day from the best licks and more than 2000 gallons per day from the poorer licks. Thus it is obvious that natural licks cannot be depended upon to supply the necessary salt for a grazing animal in this region.

Large salt grounds are recommended for Hayden Valley, Upper Yellowstone and Pelican Valley, and outside the Park, near the Cement Ranch, on Trail, Reese and Bassett Creeks. Some 10 to 15 additional salt logs inside the Park are necessary for the control of the deer bot-fly larvae. It would require the services of one man about three days per week from May 1 to September 15 to properly eare for the smaller grounds. The large ones would require stocking once or twice each summer.

The following is taken from "Dairy Cattle and Milk Production," Eckles, 1924, MacMillan :

"All animals that consume large quantities of vegetable food require salt. Carnivorous animals do not have this craving, neither do human beings that live mostly on meat. According to Bunge the cause of this salt requirement by herbivorous animals is the large amount of potassium which they consume with the plant food. The potassium is excreted through the kidneys, but while it is in the body a reaction takes place between the potassium and sodium chloride (or common salt), and the resulting compounds are excreted from the body. T'his leaves the body short in the amount of solium chloride needed, and results in the well known craving for salt (or sodium chloride). Common salt is needed, according to this view, to help expel the excess potash taken in with the vegetable food."

In experiments with cattle it has been found that when salt is withheld from the diet, emaciation, low vitality and rough coats result with the final complete breakdown of the animal. 


\section{PRESENT STATUS OF ELK HERD}

The writer counted small bunches of elk by age classes and sexes for the entire period of the study, the total so counted being 11,891. The total for the months of January, February, March and April was 10,446 which showed the following percentages:

Class No. 1-cows, including yearling and 2 yr. old females. $68.6 \%$ Class No. 2-calves Class No. 3 -bulls

Class No. 4-spikes (yearling males)

Total $\frac{2.4 \%}{00.0 \%}$

Assuming that half of the calves are females the percentages of males and females would be-males $22.7 \%$, females $77.3 \%$. The same assumption indicates double the number of spikes as the total for the yearling class or $4.8 \%$ which reduce Class No. 1 to $63.8 \%$.

To arrive at the number of breeding cows we would reduce Class No. 1 by the percentage of $2 \mathrm{yr}$. olds and the extremely old, say those over ten years of age. This would probably give a figure of not less than $40 \%$ for the breeding cows in the herd. Some small bunches counted in September have shown $35 \%$ calves, $52 \%$ Class $1,11 \%$ Class 3 and $2 \%$ Class 4 . The $5 \%$ difference between the percentage of breeding cows in April and calves in September could be easily accounted for by bear kills, coyote kills and losses from other sources.

On the basis of a herd of 12,000 in April and the average percentages as shown the division into age classes and sexes would be:

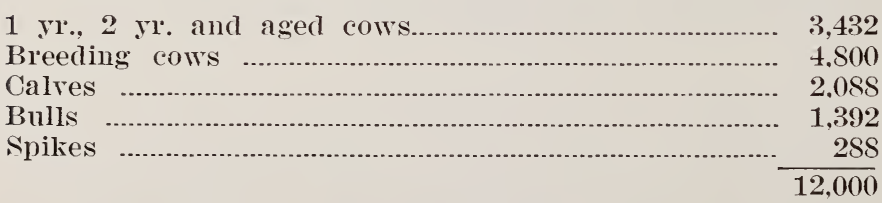

$\begin{array}{r}28.6 \% \\ 40.0 \% \\ 17.4 \% \\ 11.6 \% \\ 2.4 \% \\ \hline 100.0 \%\end{array}$

In September the division would be, assuming a $5 \%$ loss from the new calf crop, $12.6 \%$ loss from the last year's calf crop and a loss from the aged equal to the yearling class:

1 vr., 2 yr. and aged cows

Breeding cows

Calves

3,432

4,800

3,560

Bulls

1,392

Spikes

$\frac{288}{13,472}$ 
The net increase to this herd has been 1472 or $11.4 \%$ but the calf loss from the new crop between September and the next calf crop in June is $12.6 \%$. There is also a loss from hunting which has not entered into the foregoing.

Reasoning from the basis of $17.4 \%$ calves, $4.8 \%$ yearlings and $77.8 \%$ for the other ages it can readily be seen that the $4.8 \%$ class cannot live long enough to maintain the balance of $77.8 \%$. If these counts are even approximately correct they indicate a herd stationary or decreasing in numbers. The greatest error is probably in the bull count as these occupy the more inaccessible parts of the range and are most apt to be undercounted.

The results of the elk counts conducted the past few years by members of the Park Service and Forest Service are as follows :

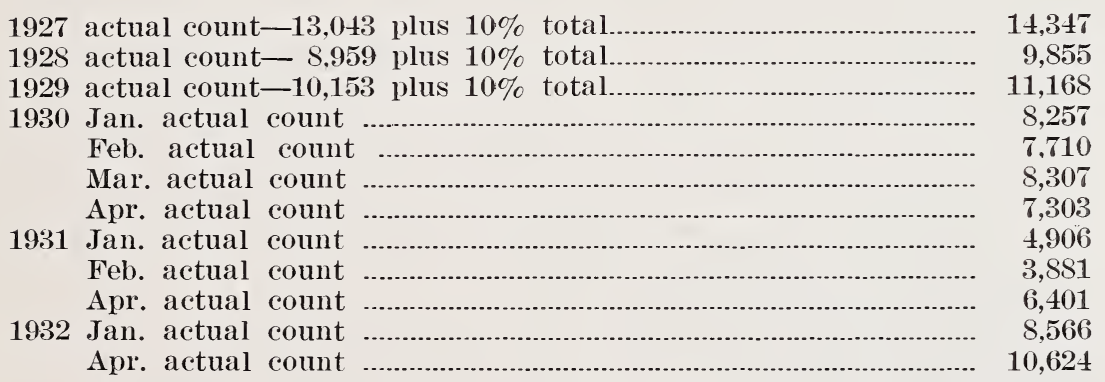

The great variance in the counts for the same year indicate a discrepancy of as much as nearly $65 \%$ and between successive years of more than $173 \%$. The April, 1932, count is nearly $25 \%$ higher than the January count.

The making of several counts in one year has proved beyond doubt that the great discrepancies between different counts cannot be explained by a possible drift of elk to other areas.

Some of the errors which account for these great discrepancies are: (1) too loose definition of the areas each counter is to cover. (2) too large areas for counters. (3) counting too late in the day. (4) unfamiliarity of the areas covered by counters. (5) estimation of large bunches in forested areas. (6) estimation of large bunches in motion. (7) movements of elk from one area to another during count. 
It is recommended that airplane counting be tried out next year in which all the herd will be counted by one or two trained observers.

The writer's conclusions are that: the elk herd now numbers between 12,000 and 14,000; the herd is not increasing; and present census methods must be materially improved to justify the time and expense of making them.

\section{WILD LIFE MANAGEMENT}

The following proposed policies are offered for the Park area.

Range destroying rodents-ground squirrels, pocket gophers, mice. Coyotes and other predators will be depended upon to keep this class of animals in check. Artificial control will be necessary whenever excessive damage is being done to the winter elk range, and in limited areas around such places as Mammoth, Buffalo Ranch and ranger stations. Shooting and trapping should be the methods employed.

Coyotes. The point is reached for artificial control measures whenever the coyote population depends almost wholly upon deer and antelope for winter subsistence. This is indicated by excessive deer and antelope kills.

The judicious shooting of old and decrepit elk that apparently will not survive the winter might well be practiced in February and March when coyote feed is scarce, in order to save deer and antelope.

Hunting and trapping by the ranger force are the control measures advocated for coyotes.

Bears. The saturation point of bears in the Park seems to be indicated by excessive damage the bears do to people and property in securing food.

Natural food for bears is of course limited, the same as the food supply of other animals, but every possibility for utilization of the surplus should be exhausted before killing is resorted to. The pathogenicity of the Russian broad tapeworm should be thoroughly workêd out before the population is reduced further. 
Wolves and Mountain Lion. It is not certain that either of these species exist at present in the Park but the area is large enough to maintain a few of each. If the numbers of these become too great control would be by hunting and trapping.

Mountain Sheep. Numbers are small and decreasing each year. There appears to be an excess of rams and museum demands for specimens could be met to a limited extent, as the bands would probably show a slower decrease, or perhaps an increase with fewer males.

Antelope. Numbers are not increasing and the bands are not large. A reduction in the number of males would benefit the bands.

Mule Deer. This species shows but little if any increase in number. Present number satisfactory. Marked decrease in numbers should be met with disease control measures and coyote control.

Moose. Not a great deal of reliable data are available on the number of moose in the Park. However, they do not seriously compete with the other animals in any way and no control measures appear necessary.

Buffalo. There seems to be no good reason why this herd should not be kept at about 1000 head through shipping live animals to zoos, etc., and butchering the remainder of the surplus. Bang's disease is prevalent in this herd and should be given careful consideration at once.

Elk. From a winter range standpoint under present distribution the present number is too large. However, with improved hunting conditions outside of the Park which will allow a better distribution and with proposed winter range additions and improvements the herd might well be increased to a maximum of 15,000 head.

It is very difficult to take an accurate census of the elk population in the Park and the results so far obtained are too uncertain to base a detailed plan of management on. The writer's best judgment is that the Northern Yellowstone herd, exclusive of the Gallatin herd, numbers between 12,000 and 14,000 elk. This is based on the census figures of the past six years and a 
knowledge of the methods used by the enumerators which indicates many parts of the winter range not covered. Counts of spikes, and yearling cows indicate that the mortality in calves between the ages of seven and eleven months is high. This explains the difference between the usual large calf crops and the net increase in the herd.

Domestic Animals. There is no room for domestic stock on the winter game ranges from a game management standpoint. Possibly some concessions may have to be made for administrative purposes, but considering the importance of the game situation the number of domestic stock allowed on the winter range should be a minimum.

The Park Service has in effect an admirable and efficient policy on dogs and cats.

Two very serious diseases in the wild animals of the Park probably incriminate domestic animals, viz: Bang's disease in the buffalo herd, of which eattle are suspected, and the Russian broad tapeworm in bears, of which dogs are suspected. Besides these some of the parasitic infestations affecting coyotes and wild grazing animals doubtless came from domesticated animals.

\section{Game Management for the Area Outside of the Park}

Ranges controlled by the Forest Service and hunting regulations controlled by State law and the Montana State Fish and Game Commission.

It is thought that an annual kill of 500 elk can safely be made in this herd with beneficial results, if the proper proportion of age classes and sexes is taken and it is the opinion of all the men who have considered the matter carefully that well regulated hunting outside the Park is the logical way to control the size of the herd.

The limited license system, practiced in Utah and some other states, promotes the best regulated hunting known. Limited elk licenses are issued to the hunters for the number and kind of elk it is desired to kill from the herd, the individual license specifies the sex and approximate age of the elk that the holder is entitled to and the area from which the elk may be taken. With such a system in practice here congregation of dozens and 
hundreds of hunters on the Park line would be eliminated and the fall migration would not be halted on the Park line with the resultant damage to the Park range. Enough elk to more fully utilize the outside range would pass out, the hunting would be in the rear of migration instead of in front and pot shooting would be eliminated to a large degree. A closed strip adjoining the Park line, approximately two miles in width east of the Yellowstone River to Jardine Mountain would be necessary to fully carry out the plan of having the hunters behind the elk. If upon the initiation of these measures it was found that not enough elk left the Park for the proper amount of hunting then certain days of the week closed to hunting would surely effect the desired result. It is thought that this last mentioned measure would not be necessary with the limited license system.

The present system has resulted in over-utilization of large parts of the range and under-utilization of other parts with a spasmodic and wholly unsatisfactory utilization from all viewpoints of the surplus elk. The average annual kill for the past four years has been less than 250 elk which is a very small number from a herd of 12,000 to 14,000 .

Range destroying rodents should be controlled within practical limits to secure the maximum amount of forage.

Coyotes and other predators should continue to be controlled by the present practice of hunting and trapping. Poisoning as a means of coyote control should not be allowed, unless it is done by experienced poisoners under the most rigid supervision.

The present laws on deer, mountain sheep and antelope are satisfactory from a management standpoint and should be continued.

For elk it is thought that the proposed improvements in methods of hunting will, if put into effect, adequately control any surplus. Calf elk should by all means be protected. Limited licenses for the number to be killed by hunters should be issued in the ratio of 50 bulls to 50 cows until more accurate data indicate that this ratio should be changed.

All domestic stock should be removed as soon as possible from the entire winter elk range. 


\section{RESPONSIBILITY OF MANAGEMENT}

The National Park Service has the responsibility of maintaining the Park areas as near as possible in the primitive condition they were before the advent of the white man. The Forest Service has the responsibility of putting the National Forests to their highest use for the greatest good to the greatest number of people. It is also mandatory upon the Forest Service to cooperate with the various state fish and game authorities to secure the best utilization of the game resources of the forest areas. The Montana Fish and Game Commission has the responsibility of supervision of wild life in Montana, and of the enforcement of all state laws relative to the wild life of the state.

The entire cost of the Government Forest and Park lands, both original and operative, is borne by the Government or the people as a whole. All of the revenue of the elk herd is received by the State of Montana.

From the standpoint of proper land management and its value to all the citizens of the State it seems clear that the measures necessary for such proper land use should be adopted by the State.

To fully protect the Park area from erosion and permanent damage to the plant life about the only recourse the Park Service has, without full State and Forest Service co-operation, is to maintain a comparatively small elk herd and handle it much the same as the buffalo herd is being handled at present.

About the only recourse the Forest Service has in handling their lands, without cooperation from the others, is to make a Federal game range of the winter elk range and handle all hunting under Federal regulations.

The ideal way, of course, is for the three agencies to agree upon the proper measures necessary for all to properly redeem the responsibilities imposed upon them by law, and proceed to put such measures into effect.

Under present conditions parts of the range are being damaged, disgraceful hunting conditions are practiced, the little utilization of the elk herd effected is unscientific and detrimental to the herd, and the state is deriving a minimum revenue from the herd. 
The cost to the Government of producing 500 elk per year from this herd is about $\$ 142$ each, the commercial value of which is less than $\$ 25$ each and the recreational value practically nil.

Under proper game management, as has been demonstrated in other states, big game animals can be made to pay a high revenue to the state, range conditions are excellent, the recreational value of real hunting realized and the numbers of the game animals increased.

Scientific management of the Northern Elk Herd is necessary for the following reasons:

1. To justify the Act of May 26, 1926, and the investment of $\$ 350,000$ for purchase of additional winter range;

2. To arrest further depletion of a large area of range land in the Yellowstone Park;

3. To promote sportsmanlike hunting of elk;

4. To secure proper utilization of this great elk herd from economic and recreational standpoints-all of which are predicated on the assumption that the land used by the game herds in this vicinity is being put to its highest use in producing game animals.

\section{RECREATIONAL VALUE}

\section{In Yellowstone Park}

The elk in this Park are a source of enjoyment to many hundreds of people each year and are becoming more so, particularly to those tourists who travel in their own cars. Some few bulls summer at Norris and attract a great deal of attention. The writer has seen one of these bulls surrounded by tourists. One venturesome tourist last July edged close enough to a large bull to almost touch it on the antlers. It is probable that several hundred photographs are taken of these few bulls each day of the tourist season up to the middle of August. Tourists can see elk at close range in Elk Park, Gibbon Meadows and Hayden Valley practically every morning and occasionally at almost every other place in the Park around the Loop.

One evening in July, 1929, a number of cars were stopped near the mouth of Alum Creek between the Lake and Canyon and a herd of about 150 elk was pointed out to the occupants 
of the autos and they were permitted to use the writer's field glasses to get a good look at the young calves playing. Some of the tourists had already seen an elk or two on their trip around the Park but none had seen such a large bunch.

Many people come to the Park in the winter and spring to see the elk and in the past special trains have been run from St. Paul, Minnesota, for this purpose. The value of the elk herds in the Park from a recreational standpoint is incalculable and ranks with the bears, geysers, and other game and natural wonders.

Outside of the Park at the present time is a totally different situation.

Elk hunting, in a literal sense, has not existed in connection with the northern elk herd, except to a very limited extent, since about 1910. Probably not more than five per cent of the total elk killed since that time have been killed by hunters. The balance has been taken by so-called hunters along the north line of Yellowstone Park at times when the elk were forced by severe weather to migrate northward down the Yellowstone River in search of food. Pot shooting into bunches of a few up to more than a hundred elk has been done many times and the resulting scramble by the "hunters" (?) after the killed and wounded animals has resembled more the expurgated accounts read of African savage ways than that of regulated hunting in North America.

The Government and other agencies have embarked upon a program of improving the range for these elk that will cost approximately $\$ 400,000$ to complete. The value of range already owned by the Government and reserved solely for elk probably exceeds this amount. The cost of winter feeding and protecting these elk is approximately $\$ 23,000$ per year. Figuring six per cent on investment and 500 elk per year, the production cost per elk is $\$ 142.00$. Surely such a cost can not be justified on the meat value of an elk, particularly as dressed elk sold at public auction to disappointed "hunter's" (?) in this region bring only about $\$ 25.00$ each.

Clearly then, some other value than meat must be got from our elk in order to justify their propagation. Our leaders since Colonial times have stressed the value of outdoor recreation, and 
have ascribed our advance in all lines of endeavor in no small part to the good we get from the outdoors. Outdoor recreation is being promoted at the present time more actively than ever before in the history of the nation and it is solely on this value, rather than the meat value, that the cost of propagating elk can be justified.

Some 4,000 to 5,000 men go to the vicinity of Gardiner, Montana, each year to shoot an elk. Practically all of them go in autos and but a small portion of them take a camp outfit along, preferring to stay in hotels or established eamps. Many return to their homes each day. Perhaps half of them do not walk more than three or four miles per day or stay outdoors for more than an hour or two. So it might be said that these men get but very little benefit from their quest for elk from an outdoor recreational standpoint.

The writer has talked with hundreds of these men in the past several years and finds that the greatest majority want meat and want to get it as easily as possible. Not all of this class are in need of meat, either, as many are professional men, merchants and ranchers who can afford to buy meat. Another smaller class want to shoot an elk for the novelty of it. A still smaller class think they are having real sport and know of no other kind of hunting. Appreciation of the elk as large game animals is totally lacking.

It has often been called to the attention of the various agencies concerned with the protection and propagation of the northern elk herd that the peculiar topography of the country between Crevice and Bear creeks along the Park line serves as a concentration point for elk migrating in the fall and also, under certain conditions of weather and concentration of "hunters" (?), a trap in which the animals are surrounded and shot. Likewise on the west of Gardiner, bunches of elk have been hemmed against the park fence by the "hunters" (?) and annihilated.

Gardiner opposition to any changes in the game laws has been of sufficient strength to prevent the State Legislature from remedying the situation and the State Game Commission is without power to change laws established by the Legislature. 
The property owners as a class and the leading business men of Gardiner would now welcome a change in game laws that would promote more sportsmanlike hunting, so it is thought that local opposition to a change is much less now than in former years.

The limited license system already described in this report would correct this deplorable hunting situation and afford the means whereby the recreational value of the elk would more nearly be approached through sportsmanlike hunting.

In justice to the whole elk problem and the people of Montana the other side of the matter should be presented. Any game animal under certain circumstances can in all fairness be classed as a nuisance and there are many cases on record where elk and deer have become so. Elk in large herds in Montana in the community where people are trying to make a living by farming and raising livestock do considerable damage to property, for which the property owner has no redress. Fences are torn down, hay stacks invaded and winter pasturage consumed, which of course rouses the farmer's ire against the elk and any program having to do with improving conditions for the elk. The severe winters of the past when literally thousands of elk starved and their carcasses were strewn over the country also had much to do with the developing of a lack of appreciation of the elk as a noble game animal in the minds of local people.

Conditions are now different, many of the ranches have been purchased for winter elk range. Livestock raising and farming have generally proved to be a non-profiting industry in this region. Many of the former settlers have sold their ranches and moved away. A better appreciation of the game animals is very slowly developing, which will be greatly accelerated upon the initiation of better hunting practices, or in other words, proper game management. 


\section{LOSSES FROM OLD AGE, STARVATION AND PREDATORS}

It is obvious that a large number of elk live to senility and die a natural death of old age. Just what percentage of the calves born live and die this way has not been satisfactorily determined. The known loss for the years 1929-1930 and 1931 attributed to old age is 44 cows and 3 bulls. A number of other carcasses found showed evidences of disease. These three winters were very mild and the losses correspondingly low. A good check was not made in the spring of 1932 which followed a comparatively severe winter but the loss is known to be very much in excess of any of the three previous winters. Of course a shortage of food hastens the death of aged animals and to draw a line between losses from old age and losses from starvation is not practicable. The writer has followed the practice of attributing to old age all losses of aged animals unless there is good evidence of the contrary.

It is also difficult in many cases to determine whether starvation or disease is the principal cause of death. One is the contributing cause to the other in many cases. A part of the heavy calf loss can be charged to starvation as the calves are weaned in the fall and on insufficient forage many succumb. The known losses attributed to starvation are, 1929-seven calves, 1930-twenty calves, 1931-none, 1932 incomplete figures, but probably 200 to 300 is very conservative.

Owing to the difficulty of finding dead wild animals on a large range, in a condition that makes determination of death possible, the known losses are but a small fraction of the total losses.

Starvation is a preventable loss and will be largely eliminated when the present proposed improvements are made on the winter range and when the complete land acquisition program is fully consummated.

The subject of losses from predatory animals must have considerable further study. In the Yellowstone Park the bears and coyotes are on an equal standing with the elk, deer, antelope and sheep in regard to protection from extermination. No doubt the bear and coyotes kill many elk calves but the balance that should be maintained between the predators and grazing animals 
requires a great deal more study than has been given it. My opinion at this time is that no bear should be killed solely because of their depredations on the elk herds but if museum specimens are required it might be well to locate and kill bear that are doing damage to the elk. The writer's observations show that a great many deer are killed by coyotes along the Yellowstone River near the mouth of Blacktail Creek. On March 15 and 16, 1929, were found six fresh kills within a mile stretch along the river, and on February 10, 12 and 13 were found 12 fresh kills in a somewhat longer stretch of river bank. The evidence against the coyote was unmistakable in every case. Fresh tracks from the hillside direct to the river, where the deer sought to escape by jumping in the water, were evident. In some cases it could be seen that the deer did escape the "ice patrol" by jumping into the water. The coyotes seem to have a regular system of deer-killing in this locality. Two or more coyotes chase the deer to the river where several more coyotes, the "ice patrol," pounce upon it and quickly devour practically the entire carcass. If such depredations are carried on over a long period the deer will soon become exterminated in that region. Clearly coyote control measures are justifiable under these circumstances.

\section{MIGRATIONS TO OTHER AREAS}

No sound evidence, pro or con, has been obtained on this phase of the problem. Tagging has been done whenever it was practicable to do so, both of corralled elk and newly born calves on the range but so far the number tagged has been too small and the elapsed time since tagging too short, to obtain any results. There is no authentic evidence that the elk are extending their range in this region. 


\section{DISEASES OF ELK}

Following are the writer's notes on the thirty post-mortem examinations conducted during the period of the elk study:

No. 1. Slaughtered January 6, 1929. No marked pathological conditions noted.

No. 2. Accidental death February 27, 1929. No pathological conditions noted.

No. 3. Old cow slaughtered March 6, 1929. Very poor physical condition. Abnormally developed rumen and intestines.

No. 4. Adult cow slaughtered. Totally blind in left eye, almost totally blind in right eye. Abscess on optic chiasma and brain. Cause of abscesses not determined.

No. 5. Aged cow died April 25, 1930. Necrosis of tissues from second pre-molar socket through to upper maxillary sinuses and molar. See photo. Partial decomposition of tissues prevented complete examination. T'ypical case of necrotic stomatitis.
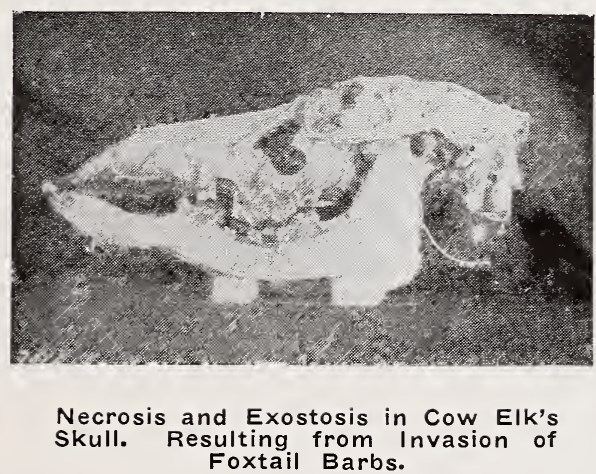

No. 6. Aged cow died April 20, 1929. Compound fracture of lower mandible caused by mechanical means. Starvation and toxemia caused death.

No. 7. Calf two days old found dead May 30, 1929. Dislocated neck vertebrae. Cause of injury undetermined.

No. 8. Five or six year old cow. Slaughtered January 31, 1930. Poor physical condition. Flabby heart muscle- 3 cysts on arteries and veins near heart. Mouth and tongue contained numerous lesions caused by foxtail grass. 
No. 9. Adult cow, slaughtered February 14, 1930. Very poor physical condition. Totally blind.

No. 10. Four or five year old cow. Died February 15, 1930. Mouth showed characteristic necrotic stomatitis lesion. Decomposition prevented complete examination.

No. 11. Aged cow, slaughtered February 14, 1930. Very poor. Did not dissect on account of extreme cold. Totally blind.

No. 12. Mature bull, died March 10, 1930. Suppurative ulcers in throat and mouth, evidently caused by foxtail grass. Death caused by toxemia from ulcers.

No. 13. Mature bull, slaughtered March 10, 1930. Gun shot wound had broken hind leg. Pericardium contained excessive amount of liquid-heart muscle infected with Sarcocystis. Lungs lightly infected with lung worms Dictyocaulus hadweni. Necrotic ulcers in mouth, caused by foxtail grass.

No. 14. Aged cow, died March 21, 1930. Few lung worms. Death resulted from old age. No pathological conditions found other than those resulting from old age.

No. 15. Aged cow, died March 25, 1930. No pathological conditions found other than those resulting from old age.

No.16. Seven or eight year old bull, died March 27, 1930. Necrotic ulcers in mouth. Second and third pre-molars missing in upper right-first and second molars loose. Necrosis of Maxilla extending through sinus and nasal passage. Necrotic material completely filled right nares. Death from toxemia.

No. 17. Aged cow, died April 4, 1930. Infested with lung worms. Heart muscle heavily infected with Sarcocystis. Old age cause of death with lung worms and Sarcocystis infection contrábuting factors.

No. 18. Calf, slaughtered April 4, 1930. Very poor condition. Heavily infested with larvae of deer botfly (Cephenomyia sp.). Necrosis of mandible. Ulcers in mouth.

No. 19. Calf, slaughtered April 4, 1930. Very poor condition. Heavily infested with larvae of deer bot fly. 
No. 20. Five or six year old cow, slaughtered April 6, 1930. Had been wounded some time previously in shoulders causing profuse suppuration extending to thoracic cavity. Heavily infested with lung worms. Infection of sarcocystis in heart muscle. Heavily infested with wood ticks (Dermacentor albipictus).

No. 21. Calf, slaughtered April 7, 1930. Contained in gutteral pouch, nares and frontal sinuses 56 larvae of the deer bot fly.

No. 22. Adult bull, putrid when found on April 3, 1930. Characteristic necrotic stomatitis lesions in mouth.

No. 23. Calf, partially decomposed when found April 3, 1930. Necrotic lesions in mouth caused by foxtail grass.

No. 24. Adult cow, slaughtered January 28, 1931. Very poor physical condition. Totally blind in left eye. Abscess the size of a goose egg in orbital socket. Marked senility of lymph glands, salivary glands and heart muscle. Congestion in left lobe of lungs. Abscess in bone of mandible. Cultures from eye showed the following organisms: Bacillus coli, Staphylococcus aureus and a Diphtheroid-streptococcus, the organisms usually associated with infectious Keratitis in domestic stock.

No.25. Very old female found on Cottonwood Creek April 2, 1931. Skull showed characteristic $\mathrm{Ne}$ crotic stomatitis lesions, such as missing teeth, exostosis and necrosis of maxilla. Probably result of eating foxtail grass.

No. 26. Aged cow, shot by Mrs. Tony Stermitz on Reece Creek, 11-19-31. Two traumata in ruman, one $3^{\prime \prime}$ in diameter, the other $11 / 2^{\prime \prime}$ in diameter, both packed with dead leaves and twigs. Contents of rumen about $80 \%$ aspen and willow leaves and twigs. Open suppurative abscess under tongue. Lymph glands in head enlarged to three times normal size, teeth badly worn and infected in sockets. Small consolidated portions in periphery of lungs. Traumata in rumen no doubt caused extensive peritonitis. Abscesses in mouth caused extensive toxemia. Eating of large quan- 
tities of coarse food caused by poor teeth and lesions in mouth, the animal being unable to bite or chew grass. Death would undoubtedly have resulted from toxemia and peritonitis.

No. 27. Calf, shot on Hellroaring slopes 4-1-31, too weak to follow herd. Very poor physical condition and extremely heavily infested with wood ticks (Dermacentor albipictus). But little food material in rumen and none in small intestine. Bones soft and porous, indicating a lack of mineral elements in its diet. Animal was below normal in size. Death would have resulted from general poor condition aggravated by wood ticks.

No. 28. Bull found dead 4-16-31. Necrosis of teeth sockets and upper maxilla indicate necrotic stomatitis.

No. 29. Calf died near Eagle Nest rock in Gardiner river canyon 2-21-32. Had been in this restricted locality since about December 30, 1931. Marked constipation-periphery of colon $91 / 2$ in. Hemorrhagic areas $1 / 4^{\prime \prime}$ dia, to $1 / 4^{\prime \prime} \times 1^{\prime \prime}$ in lumen of small intestine. Very poor physical condition. Bones very soft-ribs easily cut with knife, joints enlarged and porous indicating lack of mineral elements in diet. A marked toxemia probably resulted from a severe infection of the frontal sinuses. Death resulted from general poor condition.

No. 30. Calf died at Game Preservation ranch 3-10-32. Marked degeneration of liver affecting about onehalf of the organ. Infection of one tooth socket with resulting large pus pocket in upper jaw. Heart muscle enlarged to about twice normal size.

A review of the foregoing cases shows that the diseases of elk fall into four general classes, viz: (1) parasitic infestations, (2) bacterial diseases, (3) deficiency diseases and (4) traumatism, or disease due to mechanical injury such as gun shot wonnds. Usually two or more of these classes are found in combination. (1) Parasites. Parasites of elk range from optional occasional parasites, such as mosquitoes, flies and gnats, which do but littlè harm to their hosts, to fixed parasites, such as the larvae of the deer bot fly, tape worms and lung worms. These can readily be classed into two general types, viz: external parasites and internal 
parasites. The identification of the parasites described in this report has been done by the Zoological Division of the Bureau of Animal Industry.

No attempt has been made to learn the identity of the various flies, gnats and mosquitoes that harass the game.

The wood tick in this locality is the Dermacentor albipictus and in the nymph stage is active on the elk as early in the winter as December. At the time of trapping elk in January and February the ticks are very active and numerous. Heavy infestations are accompanied by an unthrifty condition, not necessarily resulting from, but rather predisposing to the infestation, the reduction in the functional activity of the skin in such a condition affording an inviting habitat for the parasites. Thus we find the ellk heavily infested with ticks following a winter of scarce food supply. With the coming of summer the physical condition of the elk is so greatly improved that they rid themselves of the ticks, meanwhile the parasites have deposited millions of eggs to insure their perpetuation the coming winter. The body functional and physical efforts of the elk to rid themselves of a heavy infestation of ticks consumes a great amount of energy, reducing the animal's vitality to a low state. Coupled with a deficient diet this tick infestation is the contributing cause of death in many cases. The only apparent practical remedy at this time is to provide the elk with an abundance of winter forage so that their physical condition will be such that they can withstand the drain made by the ticks.

The deer bot-fly larva is from an unknown species of fly of the genus Cephenomyia and it is believed that this parasite has caused heavy losses in both elk and deer in past years. It is probably an important factor in the calf elk losses. In our postmortem examinations we have found larvae more than an inch in length and one-quarter of an inch in diameter within oneeighth of an inch of the brain cavity, in deer. As many as fiftytwo larvae have been taken from the frontal sinuses and gutteral pouch of one deer and fifty-six from one calf elk. In a deer autopsied on January 4 two larvae were taken from the frontal sinuses which measured about 0.5 millimeter in length. By March 10 the larvae from a deer measured an averag of 13 millimeters $(1 / 2$ inch) and were attached to the mucous lining of the gutteral 
pouch. Death from this parasitic infestation may result from one or more of the following: severe inflammation of the frontal sinuses extending to the brain and causing inflammation there (encephalitis), toxemia resulting from inflammation of sinuses, strangulation resulting from the mature larvae obstructing the larynx.

The information Dr. Hall gives me on the life history of this parasite follows:

"The bot fly larvae are Cephenomyia. Owing to the lack of comparative material no closer determination can be made at the present time. Hadwen in the Journal of Parasitology, Vol. XIII, No. 1, September, 1926, gives some information on the life history of Cephenomyia trompe. This fly affects reindeer in Alaska. The summary of his information is as follows:

"1. C. trompe on the wing from June to September.

"2. It can make long flights.

"3. It deposits its larvae in the nostrils of the reindeer.

"4. The larvae grow but little during the winter months. In the spring rapid growth takes place. The expulsion of the grubs from the nose is a very painful process.

"5. After the larvae have fallen to the ground they pupate rapidly. The pupal period lasts from 16 to 31 days or up to 56 days, depending upon external conditions.

"As far as the particular species of Cephenomyia which infests elk and deer is concerned, there appears to be no information on these points."

The preventative measures recommended in Farmers' Bulletin No. 1330 for the control of the domestic sheep headfly (Oestrus ovis) was experimented with on a small scale. Salt troughs were constructed of logs with large holes bored to contain the salt. As soon as the animals become used to these salt troughs pine tar was smeared around the holes, the theory being that if some of the pine tar became smeared on the animal's nose the fly would not come near enough for oviposition. No check was possible on the results of this experiment although the deer, elk and antelope readily consume all of the salt put into the troughs. See chapter on Salting. 
Dictyocaulus hadweni is the species of lung worm infesting the elk. The infestation is not considered serious at the present time but may become so under certain conditions of concentration, climate and food supply. See chapter on Relation of Heavy use of Range to Spread of Parasites and Disease.

Sarcocystis sp. This has also been discussed in the chapter referred to above.

(2) Bacterial diseases. The disease of nectrotic stomatitis has been discussed in the chapter on foxtail grass.

Keratitis (blindness). Four cases of total blindness in elk have come to my attention and a mild eye infection in the deer at Mammoth was prevalent the winter of 1930-31. In the first case of blindness examined the tissues were sent to Washington but the cause of the disease could not be determined from the tissues. Two blind cows were killed in extremely cold weather when examination was impossible. The fourth case was a cow killed on the Game Preservation Ranch in January. Cultures were made from the eye and sent to the Jensen-Salsbery Laboratories for identification. A copy of their letter of March 16 follows:

“Mr. W. M. Rush,

Yellowstone Park, Wyoming.

"Dear Mr. Rush :

"Report is available on classification of the organisms encountered in the cultures from the eye of an elk. We found Staphylococcus aureus and Diphtheroid-Streptococci in the second shipment of cultures. The first shipment of culture on continued work yielded Staphylococcus aureus along with Colon bacilli.

"We are wondering if you are not dealing with a condition among the elk analogous to infectious keratitis in cattle. This condition is known to occur in sheep also and we would not be surprised if other ruminants would also be affected. We should be interested in the description of your cases.

"Very truly yours,

"S. J. Schilling." 
Bang's disease (Infectious or Contagious Abortion). This disease is caused by an organism known as the Bacillus abortus (Bang) and is commonly acquired through the mouth by consuming feed and drink contaminated with the germs, by licking affected animals to which the germs adhere or other objects. Proof is lacking that bulls transmit the disease through the act of service, according to U. S. D. A. Farmers Bul. No. 1536.

The presence of the organism Bacillus abortus in the uterus of a pregnant animal causes an inflammation of the chorion resulting in the premature discharge of the fetus.

Following the discovery of the prevalence of this disease in the buffalo herd in December, 1931 (See chapter on Buffalo) some tests were made from the elk.

On January 25, 1932, 35 blood samples were taken from elk in the corral at Mammoth. These all were negative according to the ordinary plate-test method in our Mammoth laboratory. These samples were sent to the Montana Veterinary Research Laboratory at Bozeman and Dr. Hadleigh Marsh reported as follows:

"My interpretation of these results is that for all practical purposes all the serums are negative, but there has been some slight sensitization. At least two of the serums indicate an exposure to the abortion organism.' Dr. Marsh used the more sensitive tube test.

On March 1 and 2, 32 blood samples were taken at Slough Creek where the elk had had a more direct contact with the infected buffalo herd. Of these three were clearly positive, 8 suspicious and twenty-one negative.

The writer's interpretation of these tests for Bang's disease is that the elk herd has lately become infected from the buffalo herd and that the disease will become prevalent in a few years, and be the cause of a much smaller calf crop.

(3) Deficiency diseases. Softening of the bones (osteomalacia) and porosity of the bones (osteoporosis) are deficiency diseases caused by a lack of proper mineral elements in an animal's diet. While in the fetal stage the mineral elements are supplied by the mother, even to the extent of depriving her own system of these elements if necessary. After birth the animal is supplied from the forage eaten. Our chemical analysis of forage plants 
on the elk range indicates a satisfactory percentage of the necessary minerals but each spring some calves are found whose physical condition clearly indicate a mineral deficient diet. It is probable that the inadequate amount of forage the calves are able to secure after being weaned is insufficient to furnish enough mineral for normal bone development.

(4) Traumatic diseases. Non-preventable diseases caused by gun shot wounds, broken bones, etc. A typical example is a tumor of the knee Hygromata found in one case. This was apparently caused by an injury to the bone of the knee which caused a rupture of a vein or artery and consisted of a collection of bloody fluid mixed with fibrin within a distended bursa.

Many of the diseases (which include parasitic infestations) described in the foregoing are not now virulent; they do not of themselves cause many deaths but in combinations some fatalities result. There is no doubt but that endemic and sporadic diseases have in the past become epidemic and caused the loss of many elk.

The writer's conclusions regarding diseases in the elk herd are that no serious diseases now exist which will not be practically eliminated by supplying the elk with an abundance of winter forage, except Bang's disease and the deer-bot fly larva. More study will be required to determine the effect of Bang's disease and to learn control measures for the bot-fly larvae. In general the elk seem to be much more resistant to diseases than deer, mountain sheep or antelope.

\section{DISEASES OF DEER}

Thirty-seven post-mortems of deer were made.

No. 1. Adult female died January 14, 1929. Choked to death from miscellaneous material taken from garbage cans. Lightly infested with lung worms.

No. 2. Fawn slaughtered March 1, 1929. Injuries on hind legs due to becoming entangled in wire fence. Infested with lung worms Protostrongylus macrotis and intestinal worms Nematodirus fillicollis.

No. 3. Fawn died January 19, 1930, apparently from injuries by elk. Lightly infested with lung worms. 
No. 4. Fawn died February 15, 1930. Necrotic ulcers in mouth containing foxtail barbs. Lightly infested with lung worms.

No. 5. Fawn died February 18, 1930. Very poor physical condition. Necrotic lesions in mouth, rumen and pelvic cavity probably caused by foxtail grass. Rumen showed three necrotic areas, one broken through causing diffused peritonitis extending to abomasum, Pericarditis also resulted from trauma in rumen. Heavily infested with intestinal worms $N$. spathiger and lung worms $P$. macrotis. Three species of external parasites were found, viz: wood tick $D$. albipictus, biting lice, Tricholipeurus sp. and sucking lice, Linognathus, sp. Death resulted from pericarditis, peritonitis and toxemia.

No. 6. Fawn died February 17, 1930. Lesions in mouth from eating foxtail grass. Traced foxtail through digestive system to abomasum. In rumen some heads were found nearly intact, in reticulum and omasum barbs were loosened from shaft and in abomasum all barbs were free from shafts. Atrophied heart muscle. In very poor physical condition. Death from toxemia.

No. 7. Fawn died February 26, 1930. Death caused by peritonitis resulting from tinfoil and gravel in blind end of caecum.

No. 8. Fawn died March 5, 1930. Heavily infested with lung worms and larvae of deer bot-fly. Necrotic lesions under tongue and on lips.

No. 9. Died March 10, 1930. Putrefaction started. Lung worms and foxtail lesions.

No.10. Found dead March 14, 1930. Larnyx swollen almost shut-lesions in mouth and throat-foxtail barbs found in mouth and larnyx-both lungs congested-few lung worms. Toxemia from foxtail lesions and suffocation from swollen throat.

No.11. Fawn died March 21, 1930. Broken mandible. Lung worms, few larvae of deer bot-fly in gutteral pouch and frontal sinuses. Starvation aggravated by presence of parasites.

No.12. Fawn killed by coyotes March 22, 1930. No pathological lesions of consequence found. 
No. 13. Fawn slaughtered March 24, 1930. Back and sides nearly bare of hair due to mechanical injury. Lung worms few. Eighteen inch square dish rag in rumen. No other pathological conditions noted.

No. 14. Fawn slaughtered March 26, 1930. Heavily infested with larvae of the deer bot-fly in gutteral pouch, pharnyx and frontal sinuses. A total of 52 larvae were found. Lung worms many. Ulcer in wall of rumen. In very poor physical condition-showed diseased condition in slow movements, dropping ears, half shut eyes and rough coat.

No. 15. Fawn slaughtered March 26, 1930. Thirty larvae of deer bot-fly in gutteral pouch, pharnyx and sinuses. Very heavily infested with lung: worms. Showed same symptoms as No. 14.

No.16. Adult female slaughtered April 4, 1930. Very poor physical condition. Twenty-three larvae of deer bot-fly in gutteral pouch. Few lung worms.

No. 17. Adult female died April 4, 1930. Foxtail ulcers in mouth, necrosis of mandible eausing loosened incisors, few lung worms, few larvae of deer botfly, heavy infestation of wood ticks. Death caused by toxemia from necrotic ulcers in mouth, with parasites a contributing factor.

No. 18. Fawn slaughtered April 6, 1930. Very poor condition. Larvae of deer bot-fly and lung worms numerous. Symptoms were sluggishness in movements, rough coat and partially closed eyes.

No. 19. Fawn slaughtered April 10, 1930. Specimens sent to B. A. I. at Washington by special request. Infested with lung worms and larvae of deer bot-fly. From the lung worms found in this specimen the new species Protostrongylus macrotus was described by Dr. G. Dikmans of the B. A. I.

No. 20. Fawn died January 3, 1931. Very poor physical condition. Abomasum and small intestines highly inflamed. Rumen contents 50\% fir twigs and needles, $10 \%$ sagebrush, $40 \%$ hay and aspen leaves. Rumen only about half full and contained excessive amount of water. Superficial 
lesions on tongue apparently caused by eating fir twigs-lung worms numerous-two larvae of deer bot-fly. Death caused by eating quantity or coarse, resinous food which resulted in inflammation of stomach and intestines.

No. 21. Fawn slaughtered January 27, 1931. Abscesses on rumen, lungs, and intestines from undetermined causes. Larvae of deer bot-fly lung worm and tape worm infestations.

No. 22. Two or three year old slaughtered March 10, 1931. Very poor physical condition. Walked with peculiar jerky gait, holding convex curvature in spine and head held downward. Infested with larvae of deer bot-fly, lung worms, and wood ticks. Encysted larvae on lungs, Cysticercus ovis and in muscles Taenia ovis the muscular infestation being heavy.

No. 23. Adult, twin pregnancy, 3 or 4 years old died March 24, 1931. Eighteen nearly mature larvae of deer bot-fly in larnyx resulted in animal choking to death.

No. 24. Found skeleton April 3, 1931. Skull showed missing teeth, exostosis, and necrosis of mandibles and maxilla.

No. 25. Fawn killed by truck October 8, 1931. No pathological conditions of consequence noted. Curdled milk in stomach and intestines.

No. 26. Fawn killed by truck October 27, 1931. No marked pathological conditions found. Light infection of sarcocystis in heart muscle. Larvae of deer bot-fly $1 \mathrm{~m} \mathrm{~m}$ in length found in nasal passage. Curdled milk in fourth stomach.

No.27. Fawn slaughtered at Mammoth January 20, 1932. Very poor physical condition - unable to stand. Two tape worms (Moniezia) totalling 140 inches in length in small intestine. Heavy infestation of stomach worms (Ostertagia ostertagi). Lungs congested. Fifteen larvae of deer bot-fly in frontal sinuses. Abscesses in left maxilla socket and under tongue. Bacteriological cultures of material from abscesses showed organisms to be ordinary pyogenic bacteria instead of the suspected $B$. necrophorous. 
No. 28. Yearling slaughtered at Mammoth January 28, 1932. Had been under observation since November for eye infection. Autopsied by Dr. Tunnicliff and writer. Cysticercus on liver identified by B. A. I. as C. sp? Cysticerous on mesentery identified by B. A. I. as C.tenuicollis Cysticercus on omentum identified by B. A. I. as C. tenuicollis. Bacteriological examination by the Veterinary Research Laboratory showed two types of organisms from the infested eyes, viz: a small coccus and a very small bacillus. Experiments are still under way at the laboratory to determine the character of this eye infection in deer, but so far the experiments indicate that the organisms are specific to deer and there is little danger of this disease spreading to other animals.

No. 29. Examined with Dr. Tunnicliff. Fawn slaughtered at Mammoth January 28, 1932. Very poor physical condition. Badly infected eyes. Necrotic abscess in upper maxilla. Exostosis of lower maxilla. Catharal inflammation of intestines. Medium infestation of $O$. ostertagi in small intestine. Abscesses probably caused by foxtail grass.

No. 30. Fawn found dead by truck driver near Whiskey Springs January 28, 1932 . Examined with Dr. Tunnicliff. Stomach full of cottonseed cake. Excessive inflammation of stomach and small intestine. Infested with tape worms (Moniezia), intestinal round worms (O. ostertagi), lung worms (Protostrongylus macrotis) and larvae of the deer bot-fly (Cephenomyia). Death caused by eating excessive amount of cottonseed cake.

No.31. Fawn found dead in feeding corral at Mammoth February 3, 1932. Very poor physical condition. Heavily infested with tape worms of the genus Moniezia. One tape worm Thysanosoma actinioides in first $3^{\prime \prime}$ of small intestine. Moderate infestation of lung worms and round intestinal worms. Abscesses on lower maxilla, probably caused by foxtail grass. Cultures from these abscesses showed the presence of the ordinary pyogenic bacteria instead of the suspected $B$. necrophorus. Death caused by heavy infesta- 
tion of parasites and poisons elaborated by abscesses in mouth.

No. 32. Fawn found dead on feeding grounds at Game ranch February 3, 1932. Trauma in rumen causing diffused peritonitis extending throughout abdominal cavity and abscesses on tongue and in mouth both caused by foxtail grass. Death caused by peritonitis and toxins elaborated by abscesses in mouth.

No. 33. Fawn found dead on Game ranch February 3, 1932. Evidently had been injured by jumping into fence around hay stack. Wound on abdominal muscle-hemorrhagic area covering entire abdominal muscles. Abdominal cavity full of pus-impacted caecum-both third molar sockets ulcerated and infected. Death caused by external injury.

No.34. Fawn found dead near hospital at Mammoth February 10, 1932. Stomach full of cottonseed cake. One tape worm Moniezia and one tape worm Thysanosoma. Inflammation of fourth stomach and intestines. Very poor physical condition. Death caused by eating excessive amount of cottonseed cake.

No.35. Fawn collected on Gardiner feeding grounds February 18, 1932. Had apparently been injured in fence. Light infestation of lung worms and tapeworms. Heavy infestation of intestinal worms $O$. ostertagi. Severe inflammation of intestines. Death caused by mechanical injury.

No.36. Fawn found dead at Keith Neilson's house in Mammoth February 21, 1932.-very poor physical condition. Severe enteritis-edema in lungs - excessive amount of liquid in pericardial saclung worms numerous. Six mature larvae of the deer bot-fly in larynx and ten immature larvae in sinuses and gutteral pouch. Death from choking on deer bot-fly larvae.

No. 37. Fawn found along Gardiner road March 3, 1932, apparently killed by coyotes. Good physical condition. Two lung worms and parasytic cyst on liver. Rumen full-grass approximately $80 \%$, dead leaves, weeds, misc. approx. $20 \%$. 


\section{Teniasis in Mule Deer}

A number of the Yellowstone Park deer came to the winter range the fall of 1930 in poor physical condition. Provisions were made for feeding hay and cottonseed cake at Mammoth, and twenty-eight deer were fed here regularly during the severe part of the winter.

As early as January 3, 1931, two fawns showed symptoms of heavy intestinal worm infestation, and powdered tobacco was mixed with the cottonseed cake as a remedy. The animals ate the tobacco readily but as the symptoms were not abated one fawn was killed on January 26 and it was found to be heavily infested with tape worms of the genus Moniezia.

On January 27 one fawn was captured, placed in confinement, fasted for 12 hours and given 120 grains of powdered areca nut in five capsules. A domestic sheep mouth spreader and capsule forceps were used in administering the drug. After another period of 12 hours this fawn was marked and released. On January 31 two fawns and on February 6 three fawns were similarly treated. One fawn was given a double dose of the medicine through mistake but showed no ill after-effects.

March 27 a fecal examination was made of one treated fawn and one untreated one, using the "salt flotation" method. No ova were found in the feces from the treated fawn. Ova of one of the round intestinal worms was found in the feces of the untreated fawn. Eight additional fecal examinations were made of five treated fawns, and three untreated does.

In the feces of one treated fawn one ovum of the tapeworm was found which would indicate that the treatment was not effective in this case. Segments of tapeworms were found in the feces of one untreated doe, the remainder of the samples being negative.

While this experiment of treating juvenile deer for teniasis gave no conclusive results as to the effectiveness of 120 grains of powdered areca nut in ridding the animals of the parasite, it does show the practicability of effective treatment in the future.

A male two or three year old deer, in very poor physical condition, was killed near Blacktail Creek on March 10. Besides 
the usual infestation of lung worms and deer bot-fly larvae this animal was found to be heavily infested with encysted larvae of the dog tapeworm, Taenia ovis, in the muscles of the back and legs. The adult form of this tapeworm develops in the coyote, from which the forage and water used by the deer becomes contaminated by the millions of ova passing out of the coyote with its feces. In the deer these ova develop to the larvae stage and become encysted in the muscles. The life cycle of the tapeworm is completed when the coyote (or other animal) ingests the raw meat of the deer, as the encysted larvae pass to the intestines without being digested and develop to the adult tapeworm.

The fact that deer in this region are infected with encysted larvae of the dog tapeworm justifies a warning against eating uncooked deer meat including dried and smoked venison, as it is possible that the encysted larvae in the muscles of the deer would develop into adult tapeworms in humans as well as in dogs and coyotes.

Larvae of another dog tapeworm (Cysticerus pisiformis) were found in the jack rabbits of this region.

The writer's conclusions regarding diseases in the deer of Yellowstone Park region are that: (1) The larvae of the deer bot-fly causes heavy losses during the winters following the summers when conditions are favorable to the bot-fly. Whether or not a wet season is favorable to the bot-fly has not been determined. (2) Moderate infestations of lung worms cause no losses but are a contributing cause to many deaths. (3) Foxtail grass (Hordeum jubatum) fed in hay causes heavy losses. The lesions, however, become infested with ordinary pyogenic bacteria instead of the $B$. necrophorus, the causative organism of calf diphtheria (Necrotic stomatitis). (4) Heavy infestations of tape worms and round worms cause some losses. Light or moderate infestations are a contributing cause to some deaths. (5) The eye infection at Mammoth has not been serious but should be closely watched and given further study. (6) The deer should be tested for the presence of the Bacillus abortus, the causative organism of Bang's disease. (7) Severe inflammation of the stomachs and intestines (enteritis) is caused by feeding cottonseed cake too heavily. Two deaths resulted at Mammoth last winter as a result of overfeeding cotton- 
seed cake. (8) Concentration of numbers of deer on feeding grounds and other areas favors the spread of diseases. (9) The losses of deer through disease and other causes probably exceeds the annual increment. (10) Control measures are practicable to a limited extent and should be adopted.

\section{ANTELOPE DISEASES}

Thirteen more or less complete antelope specimens were examined. Six showed necrotic ulcers in mouth (foxtail mouth); all showed decayed teeth to a greater or lesser degree; four were infested with lung worms Dictyocaulus sp., two with intestinal worms Ostertagia sp. and Nematodirus antilocaprae, one with tape worms Moniezia sp., all of them with wood ticks.

Not enough time was available to give this species any but the most casual attention. The importance of the antelope in this region justifies a thorough investigation into their diseases. 


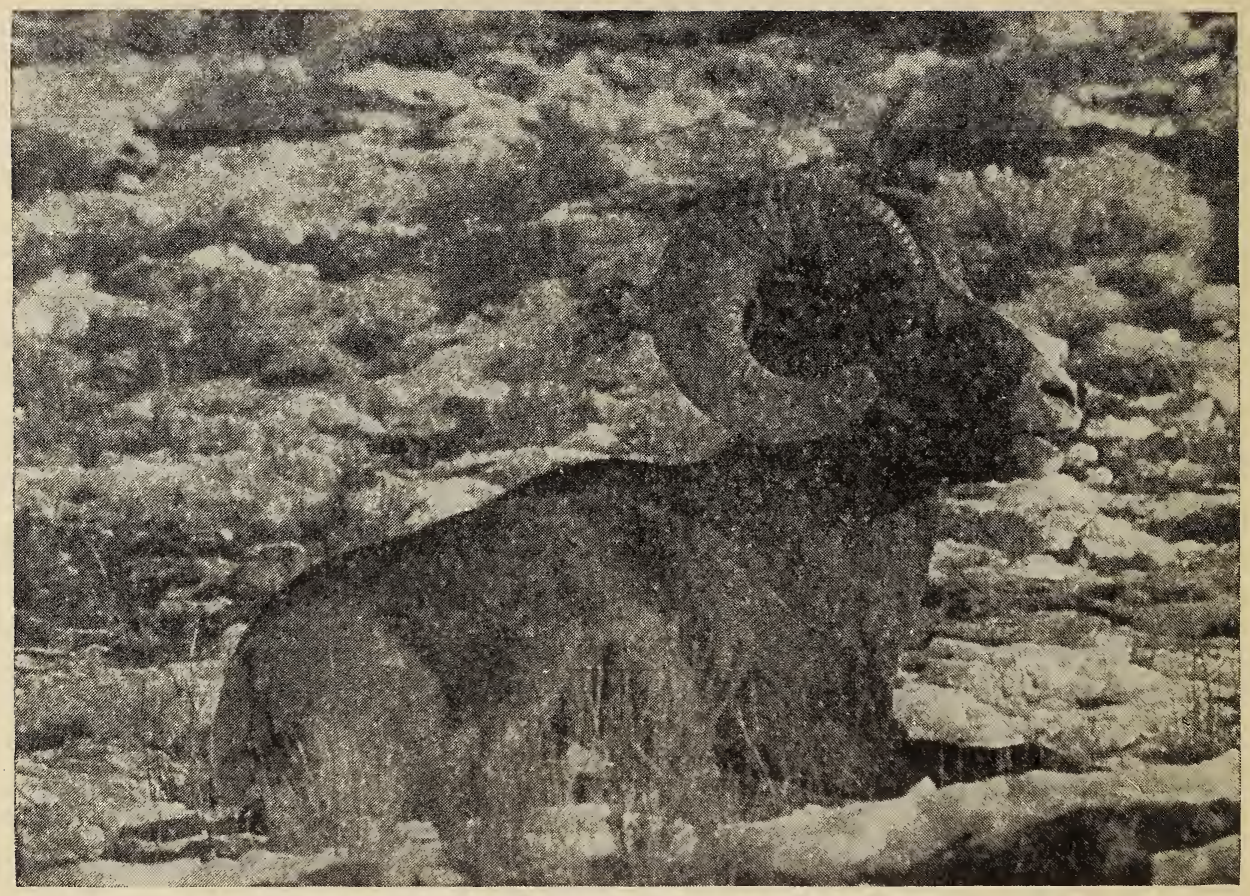

\section{MOUNTAIN SHEEP}

Two specimens were examined:

No. 1. Mature pregnant female, struck by auto and killed on February 4, 1931. Lungs badly congested, watery blisters or ulcers on exterior surface of lungs, no adult lung worms found but thousands of microscopic larvae of lung worms were evident, lungs adhered to thorax, encysted larvae of tapeworms in omentum, scab mites in outer ear.

This animal was evidently in the advanced stage of verminous pneumonia, caused by lung worms.

No. 2. Mature ram slaughtered May 22, 1931. Had been under observation since January 1-was in extremely poor physical condition and was being pestered by coyotes at time of collection.

One quart gelatinous exudate in thoracic cavitylungs loaded with mucous-hard areas on lungs one-sixteenth to one-half inch in diameter-thousands of microscopic larvae of lung worm-one adult lung worm-abomasum moderately infested with Ostertagia marshalli- 
few wood ticks-moderately infested with scab mitesvery old as indicated by teeth.

Lung worm, Protostrongylus stilesi. Bacteriological cultures from lungs yielded Pasteurella ovis and Bacillus pyogenes and from the heart blood a pure culture of diphtheroid bacillus.

This animal was in the final stages of verminous pneumonia caused by lung worms and their larvae.

\section{MOOSE}

One specimen of moose was examined. Male of uncertain age slaughtered August 7, 1931. In extremely poor condition-could walk but three or four steps without falling. Hide very rough from being pestered by flies. Found old gunshot wound just under spine between ribs-lungs adhered to pus pockets of wound on both sides-blood almost black and very thick indicating heavy bacterial infection-ribs and other bones porous and easily cut with knife-antlers in velvet and underdeveloped-uneven teeth had caused cavity in roof of mouth which was stuffed full of food particles.

Cysticercus tenuicollis, the larvae of the dog tape worm, Taenia hydatigena, in liver. Lung worms, Dictyocaulus hadweni. Four tapeworms in small intestine, Thysanosoma actinioides.

\section{BANG'S DISEASE IN THE BUFFALO HERD}

It has been noted for the past three or four years that a number of the buffalo cows aborted their calves and Bang's disease (infectious or contagious abortion) has been suspected of being the cause.

In 1930, the Bureau of Animal Industry detailed Dr. William Logan of their staff to secure some blood samples from the herd in order to determine if Bang's disease was prevalent. Due to the difficulty of getting samples of blood from live buffalo, Dr. Logan secured but five samples, three of which reacted positively to the agglutination test for Bacillus abortus, Bang-the causative organism of the disease.

At the time of butchering the surplus buffalo in 1931 (Dec. 3-10) one hundred and ten blood samples were taken and tested, both here at Mammoth by the writer and at Bozeman, Montana, by the staff of the Veterinary Research Laboratory. The results of these tests are shown on the tabulation which was prepared by 
the Veterinary Research Laboratory and is made a part of this report.

Without a complete history of the buffalo herd with such factors known as: Original numbers, sex and age ratios-number, sex and ratios each year since establishment-losses from predatory animals, butchering, shipping, etc., by years-and some idea of when Bang's disease first made its appearance in the herd, it is folly to attempt to show now the role the disease has played.

If Bang's disease causes about the same losses in buffalo that it does in domestic cattle, then we can assume that it has not played an important role in the buffalo herd to the present time as the rate of increase in the buffalo herd has been satisfactory. This would lead to two further assumptions: Either the disease has lately come into the buffalo herd and we can look for a small calf crop in the future or else the buffalo have had the disease for so long that they are more immune to it than cattle.

A few cattle were maintained at the Buffalo ranch for milking purposes until about 1919 and bulls from an outside herd were used for breeding. This is the only contact that the buffalo have had with domestic stock and it is entirely probable that the buffaloes became infected from these cattle.

Bang's disease in the buffalo of Yellowstone Park is of sufficient importance to warrant a careful study for the next several years. The writer's suggestions for a part of this study would be to test for Bang's disease 200 live buffalo next winter, making a record of the lactating and non-lactating animals, tagging each animal for identification, then test the same 200 or as many of them as possible the following two or three winters. This would give a fair test of the number of calves lost through abortion, degree of natural immunity obtained and indicate whether or not artificial control measures should be attempted. Of the preventative measures practical, probably feeding from racks instead of on the ground and the destruction of aborted fetuses, would be the most effective. It is also entirely practicable to make the abortion test at the time of slaughtering and kill only infected animals, thus ridding the herd of the diseased animals to a certain degree. Live buffalo which are shipped away from the Parks should be tested and only non-infected animals sent. 
BUFFALO BLOOD SAMPLES FROM YELLOWSTONE PARK

December, 1931

Female Buffalo

\begin{tabular}{|c|c|c|c|c|c|}
\hline \multirow{3}{*}{ No. } & \multicolumn{3}{|c|}{ Agglutination Reaction } & & \multirow{3}{*}{ REMARKS } \\
\hline & \multirow{2}{*}{$\begin{array}{l}\text { Rush } \\
\text { Plate }\end{array}$} & \multicolumn{2}{|c|}{ Mont. Vet. Res. Lab. } & & \\
\hline & & Tube & $\begin{array}{c}1 / 25 \\
\text { Rapid }\end{array}$ & & \\
\hline 2 & $\mathrm{~N}$ & & $\mathrm{~N}$ & Non-I'regnant. & Wet. Slunk. \\
\hline 3 & $1 / 200$ & $1 / 100$ & + & & Dry. \\
\hline 4 & $\mathrm{~N}$ & & $\mathrm{~N}$ & Non-Pregnant. & Dry. \\
\hline 5 & $\mathrm{~N}$ & & $\mathrm{~N}$ & Non-pregnant. & Wet. Slunk. \\
\hline 6 & $N$ & $1 / 50$ & $\dagger$ & Non-pregnant. & Wet. Slunk. \\
\hline 7 & $\mathrm{~N}$ & & $\mathbf{N}$ & Non-pregnant. & Wet. \\
\hline 8 & $N$ & & $\mathrm{~N}$ & Pregnant. & Dry. \\
\hline 9 & $\mathrm{~N}$ & & $\mathrm{~N}$ & Pregnant. & Wet. \\
\hline 10 & $1 / 100$ & $1 / 100$ & $\dagger$ & Non-pregnant. & Dry. \\
\hline 11 & $\mathrm{~N}$ & & $\mathrm{~N}$ & Non-pregnant. & Wet. \\
\hline 12 & $\mathrm{~N}$ & & $\mathrm{~N}$ & Non-pregnant. & Dry. \\
\hline 13 & $\mathrm{~N}$ & $1 / 25$ & $\mathbf{N}$ & $\begin{array}{l}\text { Non-pregnant. } \\
1 / 2.5 \text { in } 1930 .\end{array}$ & Wet. Reacted slightly \\
\hline 14 & $1 / 100$ & $1 / 100$ & $\doteqdot$ & Pregnant. & Wet. \\
\hline 15 & $\mathrm{~N}$ & $+1 / 25$ & $\mathbf{N}$ & Non-pregnant. & Wet. \\
\hline 16 & $\mathrm{~N}$ & & $\mathrm{~N}$ & Pregnant. & Wet. \\
\hline 17 & $\mathrm{~N}$ & $\mathrm{~N}$ & $\mathrm{~N}$ & Non-pregnant. & Dry. \\
\hline 18 & $1 / 100$ & $1 / 100$ & $\dagger$ & Pregnant. & Dry. \\
\hline 19 & $\mathrm{~N}$ & & $\mathrm{~N}$ & Pregnant. & Wet. \\
\hline 21 & $1 / 200$ & $1 / 100$ & $\dagger$ & Non-pregnant. & Dry. \\
\hline 22 & $1 / 400$ & $1 / 100$ & $\dagger$ & Pregnant. & Wet. \\
\hline 23 & $1 / 400$ & $1 / 100$ & $\dagger$ & Pregnant. & Wet. \\
\hline 24 & $\mathrm{~N}$ & $1 / 25$ & $\mathrm{~N}$ & Non-pregnant. & Wet. \\
\hline 25 & $1 / 400$ & $1 / 100$ & $\dagger$ & Pregnant. & Dry. \\
\hline 27 & $1 / 100$ & & $\mathrm{~N}$ & Non-pregnant. & Wet. \\
\hline 29 & $\mathrm{~N}$ & & $\mathrm{~N}$ & Pregnant. & Wet. \\
\hline 30 & $1 / 200$ & $1 / 100$ & $\doteqdot$ & Non-pregnant. & Wet. \\
\hline 31 & $\mathrm{~N}$ & $1 / 100$ & $\dagger$ & Pregnant. & Wet. \\
\hline 32 & $1 / 200$ & $1 / 100$ & $\dagger$ & Non-pregnant. & Wet. \\
\hline 33 & $1 / 400$ & $1 / 100$ & $\div$ & Pregnant. & Wet. \\
\hline 35 & $\mathrm{~N}$ & $1 / 25$ & $\mathrm{~N}$ & Pregnant. & Wet. \\
\hline 36 & $\mathrm{~N}$ & $1 / 25$ & $\mathrm{~N}$ & Non-pregnant. & Dry. Cystic ovaries. \\
\hline 37 & $1 / 200$ & $1 / 100$ & $\dagger$ & $\begin{array}{l}\text { Non-pregnant. } \\
\text { in } 1930 .\end{array}$ & Wet. Positive $1 / 200$ \\
\hline 38 & $\mathrm{~N}$ & $1 / 50$ & $\dagger$ & Pregnant. & Wet. \\
\hline 39 & $\mathrm{~N}$ & & $\mathrm{~N}$ & Non-pregnant. & Dry. \\
\hline 40 & $1 / 200$ & $1 / 100$ & $\div$ & Pregnant. & Wet. \\
\hline 43 & $\mathrm{~N}$ & $1 / 100$ & $\dagger$ & Non-pregnant. & Wet. \\
\hline 44 & $1 / 100$ & $1 / 100$ & $\dagger$ & Pregnant. & Wet. \\
\hline 45 & $1 / 100$ & & $\mathrm{~N}$ & Non-pregnant. & Wet. \\
\hline 48 & $1 / 100$ & $1 / 100$ & $\dagger$ & Non-pregnant. & Wet. \\
\hline 47 & $1 / 100$ & $1 / 100$ & $\doteqdot$ & Pregnant. & Wet. \\
\hline 48 & N & $1 / 25$ & $\mathrm{~N}$ & Non-pregnant. & Dry. 20 yrs. old (?) \\
\hline 49 & $1 / 200$ & $1 / 100$ & $\dagger$ & Pregnant. & Wet. \\
\hline 51 & $1 / 200$ & $1 / 100$ & $\dagger$ & Non-pregnant. & Wet. \\
\hline 52 & N & & $N$ & Non-pregnant. & Wet. \\
\hline 53 & $1 / 200$ & $1 / 100$ & $\mathbf{N}$ & ? Small calf a & at side. Wet. \\
\hline
\end{tabular}




\begin{tabular}{|c|c|c|c|c|c|}
\hline \multirow{3}{*}{ No. } & \multicolumn{3}{|c|}{ Agglutination Reaction } & & \multirow{3}{*}{ REMARKS } \\
\hline & \multirow{2}{*}{$\begin{array}{l}\text { Rush } \\
\text { Plate }\end{array}$} & \multicolumn{2}{|c|}{ Mont. Vet. Res. Lab. } & & \\
\hline & & Tube & $\begin{array}{c}1 / 25 \\
\text { Rapid } \\
\end{array}$ & & \\
\hline 54 & $1 / 200$ & $1 / 100$ & $\dagger$ & Non-pregnant. & Wet. \\
\hline 55 & N & $1 / 25$ & $\mathbf{N}$ & Non-pregnant. & Wet. \\
\hline 56 & $\mathbf{N}$ & $1 / 25$ & $\mathbf{N}$ & Pregnant. & Wet. \\
\hline 57 & $1 / 100$ & $1 / 100$ & $\dagger$ & Non-pregnant. & Wet. \\
\hline 59 & $\mathbf{N}$ & $1 / 25$ & $\mathbf{N}$ & Non-pregnant. & Wet. Slunk. \\
\hline 60 & $1 / 200$ & $1 / 100$ & $\dagger$ & Pregnant. & Wet. \\
\hline 61 & $\mathrm{~N}$ & $1 / 25$ & $\mathbf{N}$ & Non-pregnant. & Wet. \\
\hline 62 & $\mathbf{N}$ & $1 / 100$ & $\dagger$ & Pregnant. & Wet. \\
\hline 63 & $1 / 100$ & $1 / 100$ & $\dagger$ & Pregnant. & Wet. Cystic Ovary. \\
\hline 64 & $1 / 200$ & $1 / 100$ & $\dagger$ & Pregnant. Dry. & Coming 3 year old. \\
\hline 65 & $\mathbf{N}$ & & $\mathbf{N}$ & Pregnant. & Wet. \\
\hline 66 & $1 / 200$ & $1 / 100$ & $\dagger$ & Non-pregnant. & Wet. \\
\hline 67 & $1 / 200$ & $1 / 100$ & $\dagger$ & Pregnant. & Wet. \\
\hline 68 & $\mathbf{N}$ & $1 / 100$ & $\dagger$ & Pregnant. & Wet. \\
\hline 69 & $\mathbf{N}$ & N & $\mathbf{N}$ & Pregnant. & Wet. \\
\hline 70 & $1 / 100$ & $1 / 100$ & $\dagger$ & Pregnant. & Wet. \\
\hline 72 & $\mathbf{N}$ & $1 / 25$ & $\mathbf{N}$ & Non-pregnant. & Wet. \\
\hline 73 & $1 / 100$ & $1 / 25$ & $\mathbf{N}$ & Non-pregnant. & Wet. \\
\hline 75 & $\mathbf{N}$ & $1 / 25$ & $\mathbf{N}$ & Non-pregnant. & Wet. \\
\hline 76 & $\mathbf{N}$ & $\mathbf{N}$ & $\mathbf{N}$ & Pregnant. & wet. \\
\hline 78 & $\mathbf{N}$ & $\mathbf{N}$ & $\mathbf{N}$ & Pregnant. & Wet. \\
\hline 79 & $\mathbf{N}$ & $1 / 50$ & $\mathbf{N}$ & Pregnant. & Wet. \\
\hline 80 & $\mathbf{N}$ & $1 / 50$ & $\mathbf{N}$ & Pregnant. & Wet. \\
\hline 81 & $\mathbf{N}$ & $\dagger 1 / 25$ & $\mathbf{N}$ & Pregnant. & Wet. \\
\hline 83 & $\mathbf{N}$ & $\mathbf{N}$ & $\mathbf{N}$ & $?$ & Dry. \\
\hline 84 & $1 / 100$ & $1 / 100$ & $\dagger$ & Non-pregnant. & Wet. \\
\hline 85 & $N$ & $\mathrm{~N}$ & $\mathbf{N}$ & Pregnant. & Wet. \\
\hline 86 & $\mathbf{N}$ & $\$ 1 / 25$ & $\mathbf{N}$ & Non-pregnant. & Wet. $15-20$ yrs. (1) \\
\hline 87 & $1 / 200$ & $1 / 100$ & $\dagger$ & Pregnant. & Wet. \\
\hline 88 & $\mathbf{N}$ & $1 / 100$ & $\dagger$ & Non-pregnant. & Dry. \\
\hline 89 & $1 / 100$ & $1 / 100$ & $\dagger$ & Pregnant. & Wet. \\
\hline 90 & $1 / 100$ & $1 / 100$ & $\dagger$ & Pregnant. & Dry. \\
\hline 91 & $1 / 100$ & $1 / 100$ & $t$ & Pregnant. & Wet. \\
\hline 92 & $1 / 100$ & $1 / 100$ & $t$ & Pregnant. & Dry. \\
\hline 93 & $1 / 400$ & $1 / 100$ & $\dagger$ & Pregnant. & Dry. \\
\hline 94 & $1 / 100$ & $1 / 100$ & $\dagger$ & Pregnant. & Dry. \\
\hline 95 & $1 / 200$ & $1 / 100$ & $\dagger$ & Non-pregnant. & Wet. \\
\hline 97 & $\mathbf{N}$ & $\mathbf{N}$ & $\mathbf{N}$ & Pregnant. & Wet. \\
\hline 98 & $\mathbf{N}$ & $1 / 25$ & - & Pregnant. & Wet. \\
\hline 99 & $1 / 100$ & $1 / 100$ & $t$ & Pregnant. & Dry. \\
\hline 100 & $1 / 400$ & $1 / 100$ & $\dagger$ & Pregnant. & Wet. \\
\hline 101 & $1 / 200$ & $1 / 50$ & $\mathbf{N}$ & Pregnant. & Wet. \\
\hline 102 & $\mathbf{N}$ & $\$ 1 / 25$ & $\dagger$ & Pregnant. & Wet. \\
\hline 103 & $\mathbf{N}$ & $\mathbf{N}$ & $\mathbf{N}$ & Pregnant. & Wet. \\
\hline 104 & $\mathbf{N}$ & $1 / 25$ & $\dagger$ & Pregnant. & Wet. \\
\hline 106 & $1 / 200$ & $1 / 100$ & $\dagger$ & Pregnant. & Wet. \\
\hline 108 & $1 / 200$ & $1 / 100$ & $\dagger$ & Non-pregnant. & Dry. \\
\hline 109 & $1 / 100$ & $\dagger 1 / 50$ & $\mathbf{N}$ & Pregnant. & Dry. \\
\hline 111 & $\mathbf{N}$ & $\mathbf{N}$ & $\mathbf{N}$ & Pregnant. & Wet. \\
\hline
\end{tabular}


Male Buffalo

\begin{tabular}{|c|c|c|c|c|}
\hline \multirow{3}{*}{ No. } & \multicolumn{3}{|c|}{ Agglutination Reaction } & \multirow{3}{*}{ REMARKS } \\
\hline & \multirow{2}{*}{$\begin{array}{l}\text { Rush } \\
\text { Plate }\end{array}$} & \multicolumn{2}{|c|}{ Mont. Vet. Res. Lab. } & \\
\hline & & Tube & $\begin{array}{c}1 / 25 \\
\text { Rapid }\end{array}$ & \\
\hline 1 & $1 / 200$ & $1 / 100$ & $\dagger$ & Steer. \\
\hline 82 & $1 / 200$ & $1 / 100$ & $\dagger$ & Steer. 3 years old. \\
\hline 105 & $1 / 100$ & $1 / 100$ & $\dagger$ & Steer. \\
\hline 20 & $1 / 200$ & $1 / 100$ & $\dagger$ & Bull. \\
\hline 26 & $1 / 200$ & & $\ddot{\mathbf{N}}$ & Bull. Mature. \\
\hline 28 & $\mathrm{~N}$ & $\mathbf{N}$ & $\mathbf{N}$ & Bull. 2 years old. \\
\hline 84 & $1 / 100$ & $1 / 100$ & $\dagger$ & Bull. 4 years old. \\
\hline 41 & $1 / 100$ & $1 / 100$ & $\mathbf{N}$ & Bull. Adult. \\
\hline 42 & $1 / 400$ & $1 / 100$ & $\dagger$ & Bull. Adult. \\
\hline 50 & $1 / 200$ & $1 / 100$ & $\dagger$ & Bull. Adult. \\
\hline 58 & $\mathbf{N}$ & $1 / 25$ & $\mathbf{N}$ & Bull. Adult. \\
\hline 77 & $1 / 200$ & $1 / 100$ & $\dagger$ & Bull. 2 years old. \\
\hline 96 & $\mathbf{N}$ & $1 / 100$ & $\dagger$ & Bull. Adult. \\
\hline 107 & $1 / 100$ & $1 / 100$ & $\dagger$ & Bull. \\
\hline 110 & $1 / 100$ & $1 / 50$ & $\mathbf{N}$ & Bull. Adult. \\
\hline 74 & $1 / 100$ & $1 / 25$ & $\mathbf{N}$ & Calf. 4 months old. \\
\hline
\end{tabular}

$\dagger$ Plus

$+$

The following samples were positive, reacting at $1 / 25,1 / 50$ and $1 / 100$ : 
The non-reacting samples were negative in $1 / 25$, the lowest dilution :

$\begin{array}{rrr}97 & 111 & 16 \\ 17 & 76 & 12 \\ 28 & 5 & 2 \\ 52 & 7 & 9 \\ 69 & 4 & 19 \\ 103 & 45 & 26 \\ 85 & 11 & 29 \\ 78 & 27 & 39 \\ 83 & 8 & 65\end{array}$

A number of samples are recorded as suspicious, though not reactors. These gave some agglutination in the lower dilutions. Here the discrepancy lies between your results and ours. The tube test picked these weaker reactors more sharply than the rapid test.

$\begin{array}{rrr}98 & 24 & 15 \\ 6 & 56 & 81 \\ 104 & 59 & 86 \\ 79 & 55 & 109 \\ 80 & 58 & 72 \\ 75 & 48 & 102 \\ 61 & 13 & 36 \\ 73 & 35 & 110 \\ 74 & & \end{array}$

Breeding Record and Agglutination Test Combined.

\begin{tabular}{|c|c|c|c|c|c|c|c|c|c|c|c|}
\hline \multicolumn{6}{|c|}{ PREGNANT } & \multicolumn{6}{|c|}{ NON-PREGNANT } \\
\hline \multicolumn{2}{|c|}{ Positive } & \multicolumn{2}{|c|}{ Suspicious } & \multicolumn{2}{|c|}{ Negative } & \multicolumn{2}{|c|}{ Positive } & \multicolumn{2}{|c|}{ Suspicious } & \multicolumn{2}{|c|}{ Negative } \\
\hline Dry & Wet & Dry & Wet & Dry & Wet & Dry & Wet & Dry & Wet & Dry & Wet \\
\hline 18 & 14 & 109 & 35 & 8 & 9 & 10 & 30 & 36 & 6 & 4 & $\overline{2}$ \\
\hline 25 & 22 & & 38 & & 16 & 21 & 32 & 48 & 13 & 12 & 5 \\
\hline 64 & 23 & & 56 & & 19 & 88 & 37 & & 15 & 17 & 7 \\
\hline 90 & 31 & & 79 & & 29 & 108 & 43 & & 24 & 39 & 11 \\
\hline 92 & 33 & & 80 & & 65 & & 46 & & 5.5 & & 27 \\
\hline 93 & 40 & & 81 & & 69 & & 51 & & 59 & & 45 \\
\hline 94 & 44 & & 101 & & 76 & & 54 & & 61 & & 52 \\
\hline 99 & 47 & & 102 & & 78 & & 57 & & 72 & & \\
\hline & 49 & & 104 & & 85 & & 66 & & 73 & & \\
\hline & 60 & & & & 97 & & 84 & & 75 & & \\
\hline & 62 & & & & 103 & & 95 & & 86 & & \\
\hline & 63 & & & & 111 & & & & & & \\
\hline & 67 & & & & & & & & & & \\
\hline & 68 & & & & & & & & & & \\
\hline & 70 & & & & & & & & & & \\
\hline & 87 & & & & & & & & & & \\
\hline & 89 & & & & & & & & & & \\
\hline & 91 & & & & & & & & & & \\
\hline & 100 & & & & & & & & & & \\
\hline & 106 & & & & & & & & & & \\
\hline Tot. & 20 & 1 & 9 & 1 & 12 & 4 & 11 & 2 & 11 & 4 & 7 \\
\hline
\end{tabular}


Summary of Breeding Record and Agglutination Test.

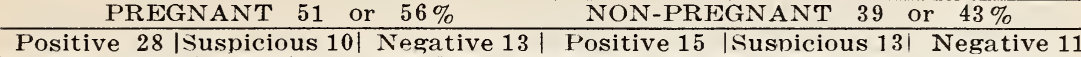

Dry | Lact'g | Dry | Lact'g | Dry | Lact'g | Dry | Lact'g | Dry | Lact'g | Dry | Lact'g 8-8\%|20-22\%|1-1\%| 9-10\%|1-1\%|12-13\%|4-4\%|11-12\%|2-2\%|11-12\%|4-4\%| 7-7\%

Summary of 1931 Calving Record and Agglutination Test.

\begin{tabular}{|c|c|c|c|c|}
\hline LACTATING & or $87 \%$ & & DRY 10 & $12 \%$ \\
\hline Reactors |Suspicious| & Non-Reactors & Reactors & Suspicious & Non-Reactors \\
\hline \begin{tabular}{l|l}
$31-38 \%$ & $20-25 \%$
\end{tabular} & \multirow[t]{2}{*}{$19-23 \%$} & $4-5 \%$ & $2-2 \%$ & \multirow[t]{2}{*}{$4-5 \%$} \\
\hline 51 or $63 \%$ & & 60 & $7 \%$ & \\
\hline
\end{tabular}

December, 1931.

Montana Veterinary Research Laboratory. Bozeman, Montana.

A check was kept on the remaining 95 buffalo slaughtered which combined with that in the foregoing table is as follows:

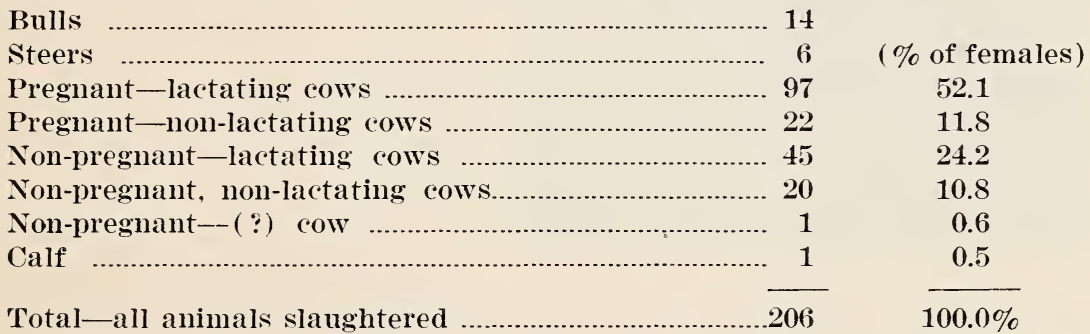

This shows that 119 cows were pregnant, of which 97 had raised calves the past season. Sixty-five were non-pregnant, but 45 of these had raised calves the past season. The total number of cows in the herd is not known so it is impossible to apply these ratios to the entire herd and compare with the number of calves actually reared during the season.

The mothers of 142 calves, out of a total of 185 calves in the corral at the time of butchering, were slaughtered. Of the total of 174 cows of breeding age slaughtered, 119 were pregnant. In view of these facts the size of next year's calf crop should furnish some very interesting data.

Of interest is the fact that of 54 fetuses examined 28 or $52 \%$ were males and 26 or $48 \%$ were females. 


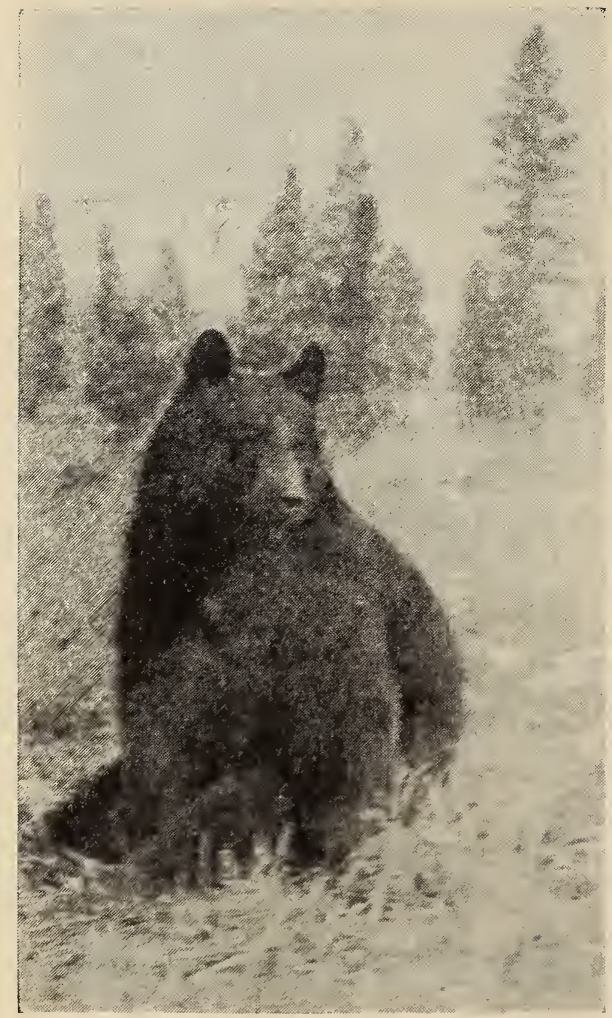

BEAR

Some experiments were conducted to determine narcotic doses for bears with the idea that important use might be made of narcotics in handling bears for shipment.

Hyoscine ( o r scopolomine), three-tenths grain was given hypodermically to a black bear weighing about 300 pounds. Narcosis was not induced by this dose but the bear gave evidence of being in great pain. A larger dose would probably have killed the animal. The dose of this narcotic for a horse is 0.125 grain.

A small bear weighing about 100 pounds was given three grains of morphine sulphate hypodermically. Narcosis was induced in about 45 minutes and lasted for nearly two hours.

Chloral hydrate mixed with honey and put on bread, given to the bear, was found to be the most practical way to put them to sleep. Three ounces of chloral hydrate, 1 quart of honey, and 1 loaf of bread seems to be the best mixture.

Mr. Carey W. Hord of the American Crayon Company, Sandusky, Ohio, a much travelled hunter.and photographer, requested me to try out the small tear gas guns on bears as he had been depending on such guns for protection against bears while taking motion pictures.

The first bear I shot with tear gas was a small black along the Tower Falls road. At the report of the gun he ran through the timber avoiding trees and down logs without a bit of trouble and came back to the road about one minute later when $I$ offered 
him some food. The charge was the regular 32 caliber tear gas cartridge fired at a distance of five feet directly into the face of the animal.

The second bear tried was a large female with three cubs on the Cody road. This bear simply whirled around at the report of the gun and immediately took some food offered her. She was close enough to observe her eyes and it was very evident that there was not a copious flow of tears.

The charge from these cartridges will produce lacrimation in a man sufficient to render him absolutely helpless for fifteen to twenty minutes. The difference in the effect of this gas on man and bear is due to the anatomical difference in the lacrimal glands and the sensitivity of the membranes of the eye. In man the eye membranes are so highly sensitive that the gas causes a severe irritation which in turn causes a copious flow of tears. The bear's eyes are perhaps not so sensitive and its lacrimal glands not constructed for a great secretion of tears.

\section{Russian Broad Tapeworm}

The discovery of the broad tapeworm in the black bear of the Yellowstone caused the writer to make a perusal of the American literature on this parasite, and believing that the matter is of sufficient interest and value to other workers and administrators in the wild life field the following resume is presented:

Name: Bothriocephalus latus, Bremser 1819; Dibothriephalus latus, Luhe 1899; Diphyllobothrium latum, Cobbold 1910. The later name has been generally accepted although both of the others are often used.

History: Probably first correctly described as a parasite of humans in Europe in 1592 and since has been subjected to a great deal of study in Europe and Japan. In parts of Scandinavia, Finland, Russia, and Germany the infestation in humans is as high as $30 \%$ to $50 \%$ of the total population; $50 \%$ of the dogs of Japan are said to be infected.

The first introduction in America was probably in 1858. An authentic case was reported in Philadelphia in 1879. Began to be common in certain areas of Michigan in 1897. Several cases 
had been reported from the northwestern states up to 1923. Fish in all of the northern row of states together with some others are at present infected with the larvae of this tapeworm to a certain extent, the infection being limited largely to lakes.

Mr. Woodbury, working with the Bureau of Fisheries at Yellowstone Lake, found the parasite in a black bear which he dissected in August, 1931. The writer found an extremely heavy infestation in a black bear August 26, 1931. Since that date a number of other cases have been noted.

Life History of the Broad Tapeworm: The adult worm lives in the intestine of some meat eating mammilian host. It has been reported from man, dog, eat, fox, lynx, and bear. For development the eggs must be deposited in water where they develop into free swimming larvae. These must be ingested by a suitable host such as some species of Cyclops or Diaptomus (small crustaceans) where the free swimming larvae further develop into what is known as a procercoid. At this stage if the crustacean is ingested by a suitable fish host, such as trout, the procercoid is liberated in the intestines and burrows through becoming encysted in the viscera or muscles of the fish. In the encysted stage the procercoid has developed to a plerocercoid. T'o complete the cycle the encysted larvae must be ingested by a suitable mammalian host where the adult worm develops.

Pathogenicity to humans: This parasite produces an intense anemia similar to pernicious anemia.

Pathogenicity to wild life: In an article by Hubbs, Carl L., Journal of Parasitology, Vol. XIV, No. 2, Dec. 1927, on "The Related Effects of a Parasite on a Fish" dealing with one species of fish which was infected with several species of flukes, one species of tapeworm, some round worms and one encysted tapeworm a number of deleterious effects are cited, the chief one being the "retention of larval features" by infected fish. This author" mentions "small size" as a result of "retentions of larval features", but does not state any conclusions regarding diminuation of egg producing capacity which would naturally result from parasitic. infestations.

Nothing was found in the literature perused on the effect of the broad tape worm on bears or other wild animals. 
On August 26, 1931, a female black bear was killed at the Lake Ranger Station because it had become so destructive to tourists' automobiles in its search for food, and upon post-mortem examination it was found to be very heavily infested with the broad tape worm $D$. latum, the individual worms measuring from 18 to 33 inches in length and numbering about one hundred.

One incomplete and to complete occlusions of the intestinal lumen and two invaginations of the intestines had taken place. The animal was in very poor physical condition.

Ten bear were caught in the live traps, used in the Park, and experimented with to determine the degree of tape worm infection and the practicability of treating them with anthelmintics, with results as follows:

No. 1. Large black male in good physical condition, very vicious. Fasted a total of five days. This bear refused to take any of the medicines offered him except on the fourth day he took a honey coated capsule containing seven minims oleum tiglii and passed one large round worm (Toxascaris transfuga). Kamala in tallow coated capsules rolled in meat, aspidium with honey and oats, capsules coated with cocoa butter, honey and powdered sugar, were offered.

A subsequent fecal examination did not show the presence of the ova of $D$. latum.

No. 2. Small black male in poor physical condition. Fasted about twenty-four hours and given seventy grams of kamala mixed with cocoa butter, honey and powdered sugar. Passed about one pint of D. latum.

As No. 2 readily took the kamala mixed with cocoa butter, honey and powdered sugar the following dose was worked out:

T'wenty-five grams of kamala, mixed with 25 grams of melted cocoa butter and 10 grams of powdered sugar. When cool and hard the mixture can be eut into squares, dipped into honey and powdered sugar. The squares are wrapped in oiled paper for convenience in carrying in the field.

No. 3. Medium sized black in fairly good physical condition. Gave above dose after fast of twenty-one hours thirty minutes. Passed about one-half pint of $D$. latum in three hours, additional one-fourth pint in four 
hours fifteen minutes and a final passage of four tapeworms after a total elapsed time from the administration of the drug of six hours, twenty-five minutes.

No. 4. Cub, about six months old. Gave five grams kamala in cocoa butter and honey coated capsules after an eight hour fast. Passed two D. latum.

No. 5. Very large black male in excellent physical condition. Gave it above dose after a fast of twenty-two hours. No tapeworms passed. Subsequent fecal examination failed to show the presence of the ova of D. latum.

Nos. 6 to 10 inclusive were trapped in October and each given 25 grains kamala mixed with honey in a sauce pan, which they readily ate. None of these passed any worms and fecal examinations showed the absence of ova. Nos. 6 and 10 were black bear, Nos. 7 and 8 were grizzly cubs and No. 9 was an adult grizzly female. The grizzlies were trapped at Beaver Lake, one black at Mammoth and the other at Madison Junction, all points twenty miles or more distant from Yellowstone Lake.

The absence of the tapeworm in the bears trapped in October at a distance of 20 miles or more from the lake may indicate one or both of two conditions, viz: the infestation in the Park may not extend beyond the lake district, or the bear may have a natural way of ridding themselves of parasites before going into hibernation. There is some evidence that most parasites are very specific in their diet and it seems reasonable that the broad tapeworm could not subsist in the intestines of a bear after it goes on a grass diet, which it does in the fall months. If such is not the case a high mortality would result during hibernation from heavy infestations, judging from the condition of the bear posted on August 26.

The foregoing experiments indicate that the parasite, D. latum, can be readily eliminated from individual bear with kamala-that the bear not in good physical condition in the summer were infected-that some bear such as No. 1 have such a disposition that they will not take any suspicious looking or smelling food while in confinement, even after a prolonged fast.

Manner of Infestation: Dogs, eats, and man become infested by eating raw or improperly cooked fish which contain the encysted plerocercoid larvae of $D$. latum. 
Liability of Human Infection: There is no danger in eating well cooked fish, and as no fish are smoked or dried in the Park the chance of human infection with the broad tapeworm is small. Centers of heavy infestation are among foreign populations where the habit of eating raw fish is prevalent.

Spread to Other Wild Animals: It is reasonable to expect that all fish-eating mammals of this region will become infected in time. This would include otter, mink, coyotes, lynx and possibly marten. However, an examination of the intestines of one otter from the West Thumb of Yellowstone Lake on March 1, 1932, showed it to be free from any intestinal parasites.

Further Study: The writer has not had time to go into this problem thoroughly. $\mathrm{He}$ is of the opinion that its importance warrants a complete study. The recommendation is also made that all bears that are to be shipped from this locality be given treatment to free them of this infestation.

Bibliography: To anyone interested I shall be glad to cite the literature on the $D$. latum that I have been able to procure.

\section{METHODS OF STUDY}

At the beginning of this study it was found that the work was naturally divided into four rather distinct lines, viz: (1) study of range conditions, (2) life histories, (3) study of diseases and (4) game management. Because of time limitations and lack of assistance not all of these branches of the study could be carried out to logical conclusions and in the case of range studies not even a good start could be made. The following is given as much for a guide to anyone else undertaking a similar study or carrying on this project, as to show the writer's methods.

Study of Range Conditions. The writer depended a great deal upon his experience in dealing with domestic stock on mountain ranges and his familiarity with the Northern Yellowstone and Sun River elk herds and their ranges for his conclusions regarding what is taking place on the elk ranges. This is not the scientific method of range study and was adopted only for the sake of expediency-to allow more time for other phases of the project. 
Some fenced and unfenced quadrats were established and charted in the spring of 1930 by the Park ranger force. However, they were altogether too few to correctly represent the entire winter range and were not charted the fall of 1930 or any time in 1931 so the results of this work have not been of any great value. With a few more quadrats and consistent charting this study will be of great value in showing the improvement or deterioration of the range.

The quadrat or mille-acre method for the study of plant succession, quadrats for volume studies, fenced and marked unfenced plots of browse for growth studies, phenological observations of forage plants, studies of exotic weed invasions and plots for erosion study, with careful and consistent follow-up will give accurate data on how the range is "standing-up" under its use.

Range research is being carried on extensively by the various state experiment stations and the U. S. Forest Service and there has been much information published on the subject.

The forage acre requirements of elk have not been worked out during this study because the writer could not devise any method of doing so under uncontrollable range conditions. Early in the study the matter of an experimental pasture where a specified number of elk could be kept isolated and accurate information obtained on their forage acre requirements was discussed and tentative plans made for such a pasture. It was apparent that a lot of other much needed information, otherwise difficult to obtain, could be readily got from such a project. The outline of this proposed plan is as follows:

Fence 1000 acres, enclosing representative range types such as conifer, aspen, willow and grassland sagebrush. Stock with 30 mature cows, 10 2-year-old cows, 5 mature bulls and 5 bull calves. Tag each animal for identification. Establish quadrats and other "yard-sticks" necessary for complete range study. Adjust number of elk in enclosure each year to carrying capacity of range. Adjust sexes until all females of breeding age bear young. Continue experiment for at least five years. Construct corrals and chutes so that individual elk can be handled.

Results to be obtained. Forage acre requirements, type of range best suited, birth rate, death rate, recovery or non-recovery from diseases, effects of ticks and other 
parasites, correct ratio of males to females, average life, effect of full feed all winter, effects of feeding artificial foods, determination of surplus to expect under bettered conditions, etc.

Such a project would entail the expenditure of considerable money for construction and installation besides current expenses for keeping observations up to date but would be amply justified by the results obtainable. An additional value would be secured if the pasture could be located where tourists would be sure to get a view of the elk.

Three methods have been used to find out what particular plants elk eat, viz: (1) direct observation or with field glasses, (2) examination of stomach contents and (3) "follow-up." Usually elk are too wild for the first method-a person cannot get close enough to tell the species of the plants selected; however, a tame elk is occasionally encountered which allows some valuable observations to be made. The second method is good during the hunting season and at other times when stomachs can be obtained, but because of the fragmentary condition of all the plants in the stomach species are difficult to identify. The third method, where the observer follows some distance behind a band of elk and notes the plants that are freshly grazed, is the most valuable on the summer range. This last method is, of course, valueless on the closely grazed winter range where the plants are dried and it is impossible to tell whether or not they have been freshly grazed.

Salting as means of influencing the drift or securing a better distribution deserves more study. It has been conclusively demonstrated that elk crave salt and readily consume all that has been put out for them. A minimum of $3 \mathrm{lbs}$. per elk per season is recommended. As a means of attracting elk to points near the main roads where the tourists may more conveniently see them, salting has great possibilities.

Fifteen salt grounds have been established for deer, elk, and antelope and one exclusively for elk in Hayden Valley. Lack of time and salt has prevented this experiment from showing anything other than the rapid consumption of the salt by the game animals as fast as it was put on the salt grounds. 
Life history studies. Several excellent outlines for the study of Mammalian Life Histories are available. U. S. D. A. Misc. Pub. No. 86, Outlines for the Study of Mammalian Life Histories by Walter P. Taylor, October, 1930, is perhaps the most complete. There is hardly any limit to the detail in which any species can be studied but time is not available in a project of this sort for exhaustive life history studies of the wild animals. Facts which have a bearing on management should, however, be carefully searched out.

Study of Diseases. This is a field in which but little work has been done and shortly after the start of the elk study it assumed a major part in the whole job. It was thought at the start that other agencies would carry on the greater part of this phase of the project but it soon developed that most of the disease study must be done on the ground. There is but little in the literature to guide a worker. A comparison as closely as possible to similar conditions in domestic stock is about the only recourse. After a lot of floundering around the following procedure has been worked out:

Symptoms are closely watched for. A sick animal is kept under observation for several days if possible to determine characteristic symptoms (with elk this is most difficult). Animals found dead or those that are slaughtered for examination are carefully autopsied in the field, or in the laboratory if practicable. A systematic routine is followed based on Dr. W. J. Crocker's "Veterinary Post-mortem Technic" (J. B. Lippincott Co. Philadelphia). Specimens of parasites found are forwarded to the Zoological Division of the Bureau of Animal Industry, Washington, D. C., for identification. All available literature on the particular parasites found is consulted to determine their distribution, occurrence, pathogenicity, etc. If possible the ova and larval forms of each parasite are studied.

Cultures are made from bacterial infections and sent to some laboratory for identification. The Montana Veterinary Research Laboratcry at Bozeman have signified their willingness to work out the identification of pathogenic bacteria for this laboratory.

Whenever conditions seem to justify the expense one of the State or Federal veterinarians is requested to come to the Park 
for a short time. Since the initiation of this project Dr. Wm. Logan of the Bureau of Animal Industry, Dr. Frank Nelson of the Livestock Sanitary Board, Drs. Marsh and Tunnicliff of the Montana Veterinary Research Laboratory have each made one or more trips here for the purpose of helping out in wild animal disease study.

Reference works which have proved most useful are:

Path. \& Ther. of the Dis. of Domestic Animals, Hutrya \& Marek. Eger. Chicago. cago.

Vet. Phar. Mat. Med. \& Ther. Milks. Eger. Chi-

Man. of Vet. Bacteriology. Kelser. Williams \& Wilkins, Baltimore.

Vet. Post-mortem Technic, Crocker, Lippincott, Philadelphia.

Parasites \& Parasitosis of Dom. An. Underhill, Macmillan, New York.

Diseases of Cattle, Special Report U. S. D. A. 1923

Prac. Bac. Blood Word \& Parasitology. Stitt. Blakiston, Phil.

Dis. Transmissible from An. to Man., Underhill, Macmillan, New York.

U. S. D. A. and State Ex. Sta. bulletins on every disease known to exist in domestic stock in the United States.

Much valuable information on how to care for and ship pathological specimens to the laboratory, methods of taking blood samples, methods of making fecal examinations, etc., is contained in a catalog issued by the Jenson-Salsbery Laboratories, Inc., Kansas City, Missouri. This publication, however, is issued to practicing veterinarians only.

While disease investigations is a specialized science it is just about as easy to train the man versed in the other branches of wild life study to do the disease work as it would be to train a veterinarian to do the other work required. Probably the best results are obtained with the wild life man, who is well versed in the essentials of disease study, working in conjunction with the veterinary-pathologist. 
The writer feels that wild animal disease study is of first importance, especially in the National Parks, and the results already obtained during the elk study clearly indicate this.

Management. Game management means the production of the largest number of game animals, consistent with the carrying capacity of their range, and the best possible utilization of the surplus over the carrying capacity.

The Park Service's policy of giving all the species of animals in the parks equal rights to survive inhibits the production of a large herd of elk to the detriment of the range and consequently to the other grazing animals such as deer, sheep and antelope. The predatory animals and even the range destroying rodents, such as the pocket gopher, ground squirrels and badgers, must be considered in the plan of management. It is obrious that intensive study to scientifically give each animal its place, in the proper numbers, in any large area such as a National Park, is out of the question. Broad practical principles must be adopted based on known factors and modified as experience dictates. For instance, coyotes can be depended upon to keep the range destroying rodents in check. Coyotes must be kept in check by mankind and the point where mankind must take a hand is indicated by excessive deer and antelope kills by coyotes. The saturation point in the bear population is reached when bear become excessively destructive to property in their search for food, or, kill an excessive number of young elk. Orer-population of an area by grazing animals is indicated by over-grazing.

The Yellowstone Park situation can be summed up as follows :

Range destroying rodents are not doing excessive damage.

Coyotes might well be reduced to a lower point, to save the deer and antelope.

Deer are increasing very slowly, if at all, do not require a great deal of range and might well be increased.

Antelope are not increasing and should be given all favorable consideration possible with a view of increasing their numbers.

Mountain sheep are decreasing-should be allowed every means possible for increase in numbers. 
Moose do not compete with other grazing animals to any appreciable extent for forage and should be allowed to increase in numbers.

The buffalo herd is kept at about 1000 head and there does not seem to be any good reason why this number should be changed.

Bears will be kept in check because they become excessively destructive to property and dangerous to tourists when their numbers become such that their food supply is insufficient.

A part of the elk herd leaves the Park each year and is subject to the laws of Montana, so it is evident that the greatest need for management is in this species of animals.

The methods of working out the necessary reforms in the state laws have been to contact as many of the local residents, hunters, legislators, public officials, sportsmen's associations, etc., as possible, trying to point out how different methods of hunting would benefit all parties concerned.

The reforms desired are largely the result of the writer's experience coupled with a study and observance of the hunting methods in other states.

Every detail in the wild life study should have as its objective better wild life management in the broader sense in which the term "wild life management" is defined.

The foregoing outline of "Methods of Study" is intended to show only the main avenues of approach to a wild animal study, the thousand and one details are mostly a matter of experience and extensive study of the results of other workers in this and allied fields.

\section{SUMMARY}

(1) The results of the elk study project and allied work have been presented by 16 published articles, 9 unpublished memoranda and reports and 6 papers and addresses before scientific and conservation meetings. In this publication the material has been somewhat condensed and presented in a more logical sequence. 
(2) Methods of study were developed which are believed to be especially suited to special problems of this kind.

(3) Summer range conditions could be improved by more salt grounds.

(4) The winter range inside the Park has deteriorated more than $50 \%$ since 1914 due to overgrazing and drouth. Both sheet and gully erosion are taking place. Non-forage plants are taking the place of valuable forage plants. Obnoxious grasses and weeds are gaining strong footholds in the Park. Browse species of forage will disappear in the next 15 to 20 years if a marked improvement does not take place in the range in the next five years.

(5) The range outside the Park should be put to its highest forage producing capacity at once by (a) reseeding of cultivable lands, (b) irrigation along existing ditches and (c) removal of sage brush on some areas.

(6) Artificial feeding has proven to be detrimental to game animals rather than beneficial.

(7) Because of the peculiar nature of elk it is impracticable to practice scientific range management on the elk range and a relatively large acreage per elk is necessary for their propagation.

(8) The use of important parts of the winter elk range in the Park by commercially used horses materially affects the amount of forage left available for elk.

(9) Domestic stock is still using considerable forage in the area outside of the Park that would be a valuable addition to the present winter food supply of the elk herd.

(10) Hunting methods are at present very unsatisfactory and could be much improved by the adoption of the limited license system.

(11) Salting is very necessary for the well being of the elk herd.

(12) Disease is an important factor in limiting the increase of the game herds and deserves considerable further study. 


\section{RECOMMENDATIONS}

1. Studies should be continued on the following:

(a) complete range study along scientific lines, intensive grazing reconnaissance of winter range.

(b) disease studies, particularly Bang's disease in buffalo and elk, Russian broad tapeworm and other parasitic diseases.

(c) Management-studies in experimental pasture.

(d) better methods of taking elk census.

2. No means should be taken to increase the present size of the elk herd until range conditions materially improve. Size of herd at present between 12,000-14,000.

3. For range improvement:

(a) artificial reseeding (Ref. U. S. D. A. Cir. No. 178 Aug. 1931, Artificial Reseeding on Western Mountain Range Lands).

(b) graze buffalo above drift fence in spring instead of in Horseshoe.

(c) no horses on winter range.

(d) attempt to hold elk outside of Park longer in the spring and adopt hunting measures allowing more elk to leave Park earlier in the fall.

(e) reseed cultivable lands outside Park to pasture grass.

(f) irrigate favorable areas along existing ditches.

(g) remove sage brush from areas of exceptionally good soil.

(h) control range destroying rodents where necessary.

(i) remove domestic stock from outside range.

4. Cessation of feeding hay at Game Protection ranch. Feeding to be continued at Slough Creek until winter range shows marked improvement.

5. Limited permit system for killing elk; permit to specify; district, sex of elk to be taken, no calves to be killed. Closure of two mile strip north of Park from Yellowstone river east 
to Jardine mountain. Five hundred elk to be killed each year until more accurate data indicate this number should be changed. Ratio $50 \%$ males, $50 \%$ females.

6. Installation of salting practice on elk range comparable to that in effect on National Forest cattle ranges.

Respectfully submitted.

W. M. RUSH,

In Charge Elk Study.

Missoula, Mont., April, 1932. 


\section{INDEX}

PAGE

Acknowledgments

Antelope

$79,81,105$

Antlers, chemical analysis of

Artificial feeding

36,66

Artificial reseeding

Bears

Blacktail range

78,114

Breeding age

Breeding season

Buffalo

Bugling

Calving

Cats

Census

Climate

$76,77,78,79$

Color

Compatibility

Control of Weed Pests ..................................................................

Costs of Producing Elk ......................................................................

Cottonseed Cake ............................................................................

Courtship

Coyotes ….......................................................................

Damage done by elk ..................................................................

Deer .....................................................................................................

Diseases of antelope .................................................................................. 10 5

Diseases of bear ..........................................................................114 to 119 inc.

Diseases of buffalo .........................................................................

Diseases of deer …….......................................................................

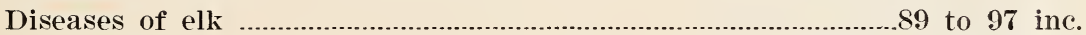
Parasites ...................................................................... 92, 93. 94

Bacterial ................................................................................ 61, 95, 96

Deficiency ............................................................................

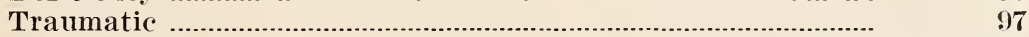

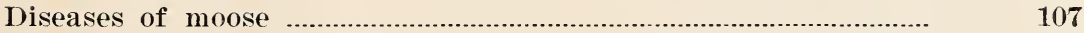

Diseases of mountain sheep ............................................................. 106

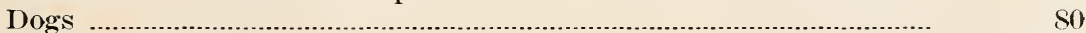

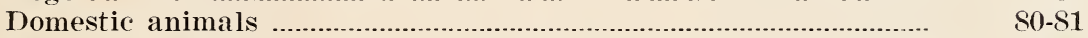

Elk Park Range .............................................................................

Enemies of calves ...............................................................................

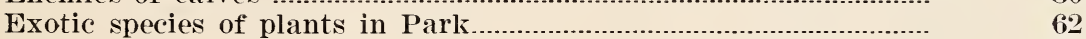

Fights ........................................................................................

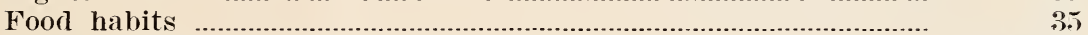

Foxtail grass ................................................ 54.63

Foxtail grass, effects of, on game animals.......................................

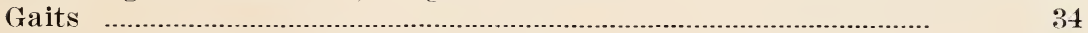

Game management outside the Park............................................. 80

Gardiner range ....................................................................................

General breeding habits .................................................................

General habitat ....................................................................... 28

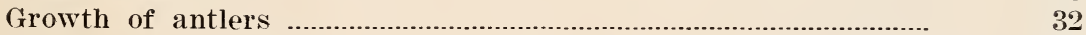

Hayden Valley range ................................................................................

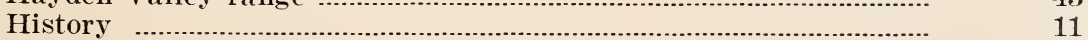

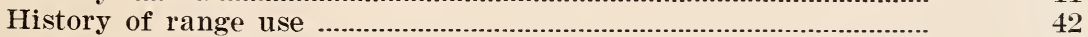

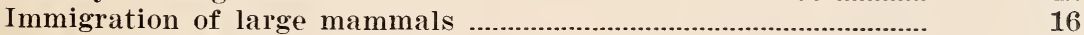


Lamar Valley range

License system

Life history

Iife zones

Tosses from old age, starvation and predators

Management, responsibility of

Methods of study

Migration

119 to 125 inc.

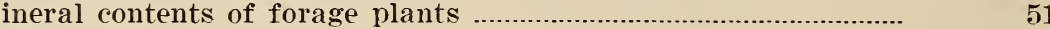

Mineral requirements of elk ....................................................... 52,53

Moose

Mountain lions

79

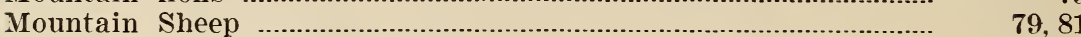

Mule deer

Norris range

Nursing periods

44

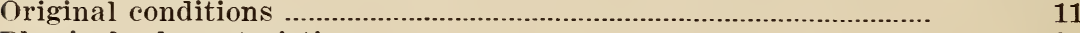

Physical characteristics ….............................................................

Physiography of region …………...................................................

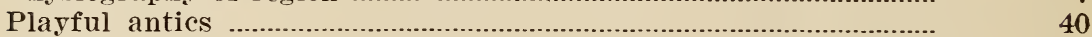

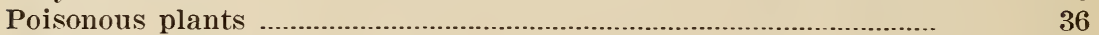

Postures ……..................................................................................

Range conditions ...............................................................................

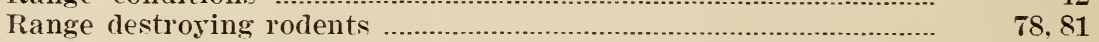

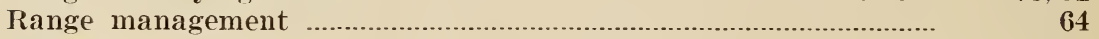

Ranges

Blacktail range

Elk Park range

Gardiner range

Hayden Valley range

Lamar Valley range

Norris range

Summer range

Swan Iake Flats

Winter range

Winter range inside Park.

Winter range outside Park

67

Recommendations

Relation of heary use of range to spread of parasites and

diseases in animals

Reproduction

Responsibility of management

Russian broad tapeworm

Salting

Shedding of antlers

soils, chemical analysis of

Speed

Statement of project

Status of elk herd

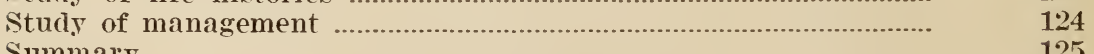

Summary

Summer range 
Swimming

PAGE

Temperaments

Values

Commercial

Recreational

83

Water, chemical analysis of

\$3, $8.5,86$

Weed pests on winter range ..........................................................

Weedy abandoned fields, treatment of ............................................... 71

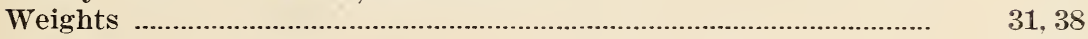

Wild life management ......................................................................

Winter range ...................................................................................

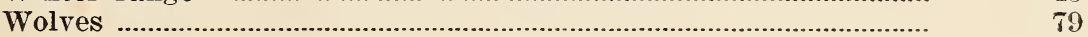


(opies of this report may be obtained from STATE GAME WARDEN

Helena, Montana

Price 50 cents each

THE MISSOULIAN PUBLISHING COMPANY MISSOULA, MONTANA

anging 


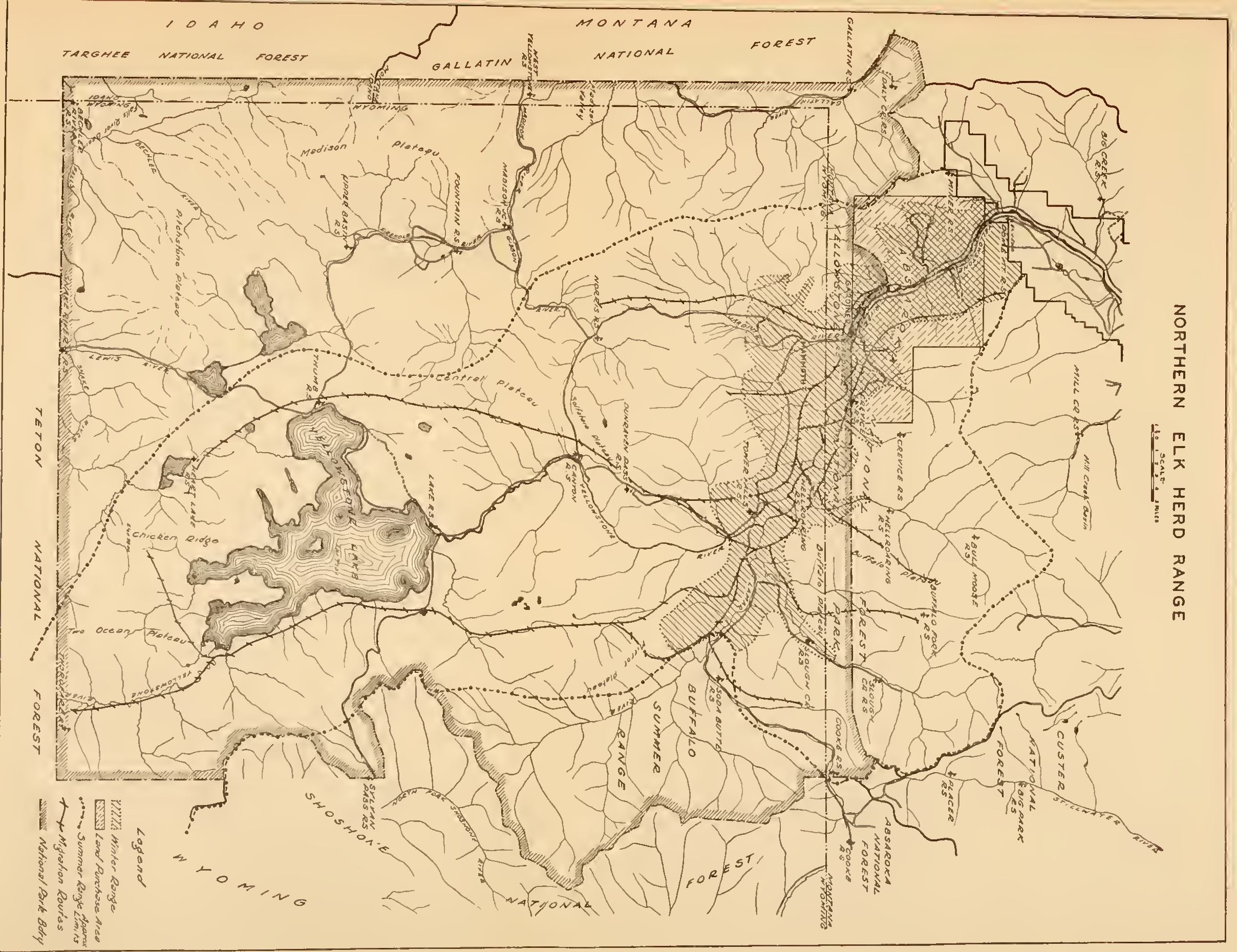





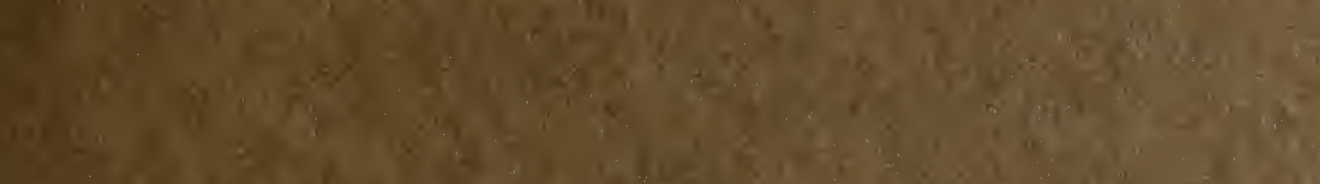

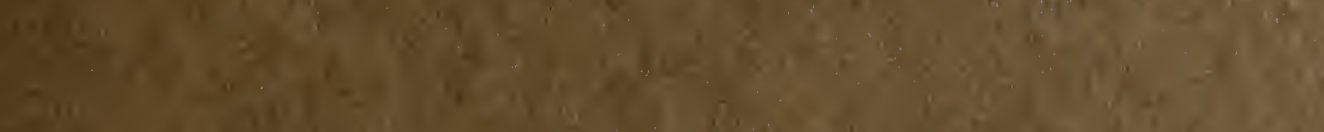

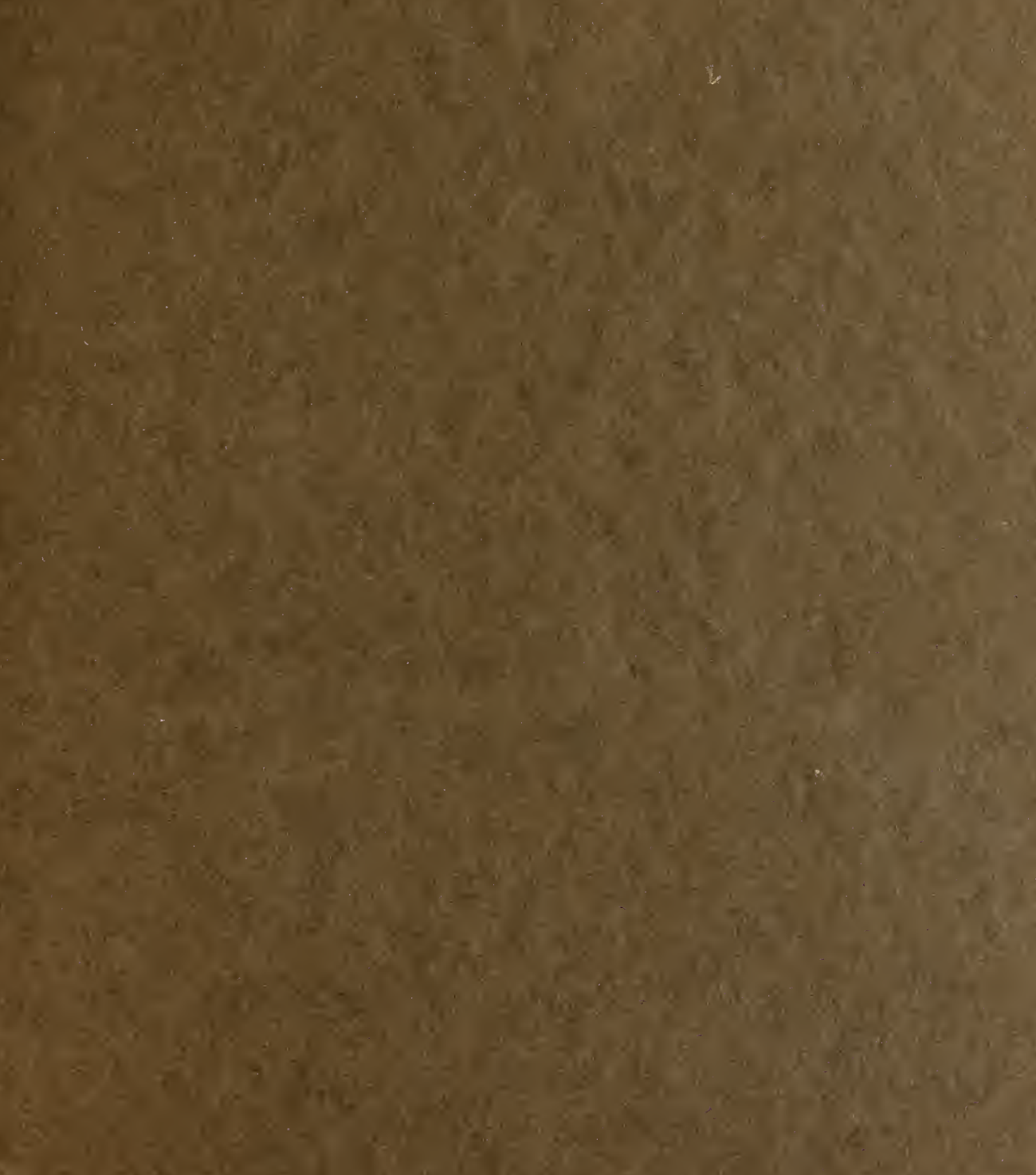

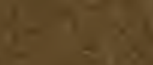
C.

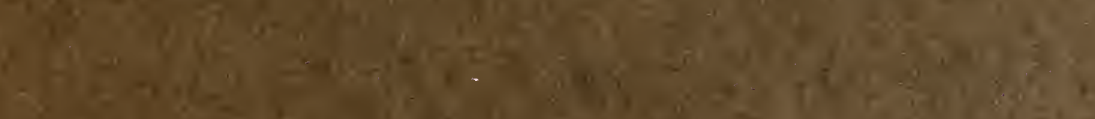

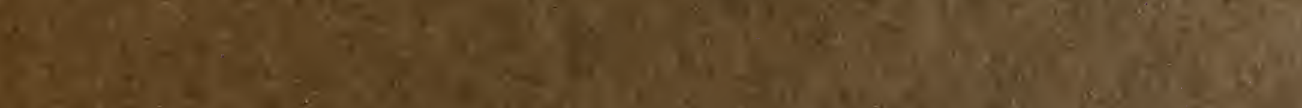

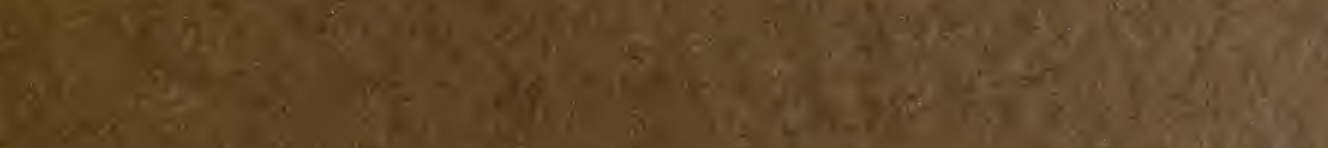

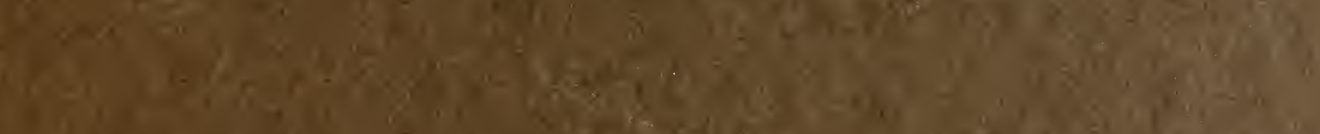

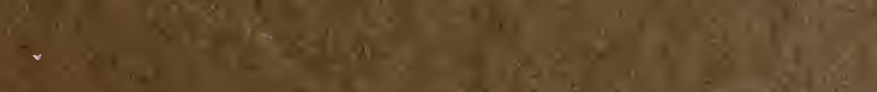

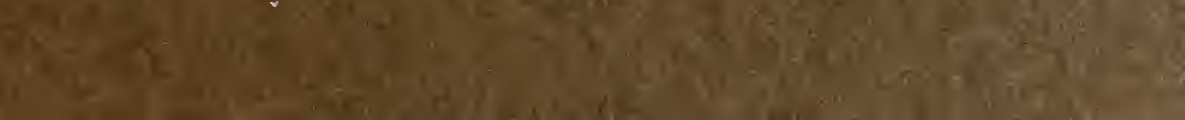


